UNIVERSIDADE DE SÃO PAULO

FACULDADE DE ECONOMIA, ADMINISTRAÇÃO E CONTABILIDADE DEPARTAMENTO DE ADMINISTRAÇÃO

PROGRAMA DE PÓS-GRADUAÇÃO EM ADMINISTRAÇÃo

DIFERENCIAÇÃO E GERAÇÃO DE RENDA NOS SISTEMAS AGROINDUSTRIAIS

Bruno Varella Miranda

Orientadora: Prof ${ }^{\mathrm{a}}$. Dr ${ }^{\mathrm{a}}$. Maria Sylvia Macchione Saes

São Paulo

2009 
Prof $^{\mathrm{a}}$. Dr ${ }^{\mathrm{a}}$. Suely Vilela

Reitora da Universidade de São Paulo

Prof. Dr. Carlos Roberto Azzoni

Diretor da Faculdade de Economia, Administração e Contabilidade

Prof. Dr. Isak Kruglianskas

Chefe do Departamento de Administração

Prof. Dr. Lindolfo Galvão de Albuquerque

Coordenador do Programa de Pós-Graduação em Administração 


\title{
DIFERENCIAÇÃO E GERAÇÃO DE RENDA NOS SISTEMAS AGROINDUSTRIAIS
}

\begin{abstract}
Dissertação apresentada ao Departamento de Administração da Faculdade de Economia, Administração e Contabilidade da Universidade de São Paulo como requisito para a obtenção do título de Mestre em Administração
\end{abstract}

Orientadora: Prof ${ }^{a}$. Dr ${ }^{\mathrm{a}}$. Maria Sylvia Macchione Saes

\section{SÃO PAULO}


FICHA CATALOGRÁFICA

Elaborada pela Seção de Processamento Técnico do SBD/FEA/USP

Miranda, Bruno Varella

Diferenciação e geração de renda nos sistemas agroindustriais / Bruno Varella Miranda. -- São Paulo, 2009.

$102 \mathrm{p}$.

Dissertação (Mestrado) - Universidade de São Paulo, 2009.

Bibliografia.

1. Custo de transação 2. Economia institucional 3. Renda agrícola 4. Agricultura familiar I. Universidade de São Paulo. Faculdade de Economia, Administração e Contabilidade II. Título.

CDD - 338.5142 
À Alda Carolina Coraça, Isabel Ribeiro Varella e Lucília Miranda. 


\section{AGRADECIMENTOS}

Agradeço aos meus pais, João e Maria Cândida, e à minha irmã, Denise, pelo amor e apoio incondicionais.

Ao CNPq, pelo auxílio financeiro a esta pesquisa.

Aos professores e colegas do PENSA, companheiros nesses últimos anos. Um agradecimento especial à Nice Santana.

À Universidade de São Paulo, minha segunda casa desde 2002.

Aos professores Rubens Nunes e Ana Célia Castro, pela participação em meu exame de qualificação.

À Daniele Giovannucci, pela recepção quando de minha visita aos Estados Unidos no início de 2008.

À Beatriz Saes e Paula Schnaider, pelo auxílio na coleta dos dados aqui utilizados.

Àquela "meia dúzia" de sempre, amigos que muito me auxiliaram ao longo dessa etapa.

Finalmente, agradeço à Prof ${ }^{a}$ Sylvia Saes, por toda a confiança depositada. 


\section{RESUMO}

O presente trabalho discute a relação entre a diferenciação na produção e a geração de renda nos sistemas agroindustriais. Dividido em três artigos, seu objetivo é apresentar uma interpretação para a dificuldade dos produtores rurais de aumentarem sua participação na renda total gerada nessas cadeias. Ao longo das próximas páginas, um aspecto do cotidiano dos agricultores será especialmente debatido, qual seja: o processo de obtenção das informações relativas aos mercados em que participam. Conforme será demonstrado a seguir, nem sempre a diferenciação sucede a plena identificação de uma oportunidade de obtenção de rendas extraordinárias. Pelo contrário, não raramente os custos ligados à busca dessas informações são demasiado altos. Com isso, a diferenciação seria estimulada por agentes capazes de colher esses dados, e que forneceriam incentivos para $o$ estabelecimento de uma relação cooperativa. Tendo em vista a possibilidade de adoção de estratégias oportunistas, porém, tal dependência pode abrir espaço para a ocultação parcial das informações relativas ao valor gerado a partir da especialização produtiva. Por outro lado, a existência de enraizamento social nas relações econômicas poderia contribuir para a transferência de informações aos parceiros comerciais ainda quando sua obtenção fosse improvável. A dificuldade de obtenção dessas informações constituiria um aspecto fundamental na dinâmica dos sistemas agroindustriais inclusive naqueles mercados organizados em torno de uma certificação. Nestes, a obtenção das informações relevantes deveria ser, teoricamente, facilitada aos agentes. 


\begin{abstract}
The following thesis discusses the relation between productive differentiation and rent generation in agro-industrial systems. Divided in three articles, its goal is to present an interpretation to the difficult of agricultural producers to increase their participation in the total rent created in these chains. In the next pages, one aspect of producers' routines will especially be discussed: the process of gathering information relative to the markets in which they take part. In many cases, differentiation processes do not respond to the identification of a business opportunity. Instead, the costs associated to the search of this information are prohibitive for many agents. So, the responsible for the identification of a business opportunity will provide the incentives to other agents, in order to convince them to engage in a specific economic relation. However, agents based on opportunistic motivations may hide part of this information, providing incentives which don't correspond to the right payoff of each contribution. In other hand, the existence of social embeddedness in an economic relationship is a factor which may guarantee the transference of information even when it would be impossible to the agents to search this data by themselves. The problem presented here has a pervasive nature, since it can be found in almost every market.
\end{abstract}




\section{SUMÁRIO}

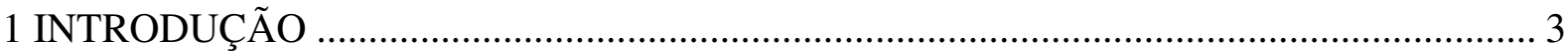

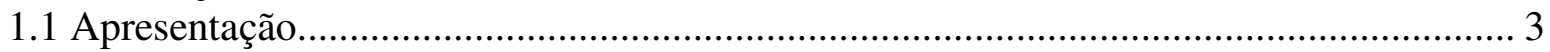

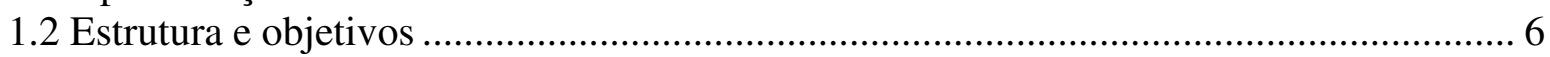

1.3 Diferenciação e distribuição da quase-renda ............................................................... 8

$1.4 \mathrm{O}$ enraizamento e a transferência de informações ............................................................

1.5 Certificação e a inserção mercadológica dos cafeicultores ........................................... 10

2 OS CUSTOS DE DESCOBERTA DOS PREÇOS RELEVANTES E A

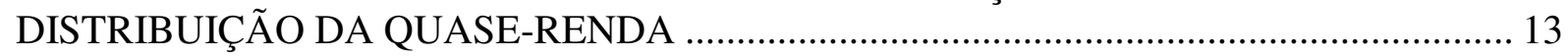

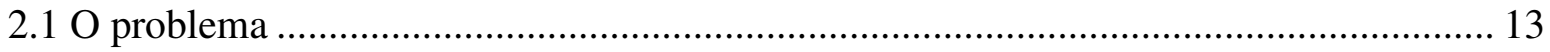

$2.2 \mathrm{O}$ neoinstitucionalismo econômico e a lógica da eficiência ............................................. 14

$2.3 \mathrm{O}$ uso do mecanismo de preços e a firma coaseana..................................................... 18

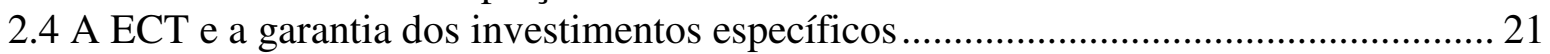

2.5 Investimentos idiossincráticos e a determinação da quase-renda ................................... 26

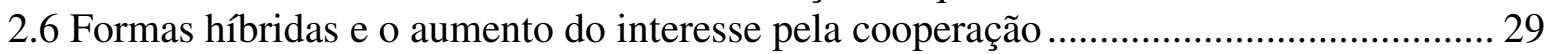

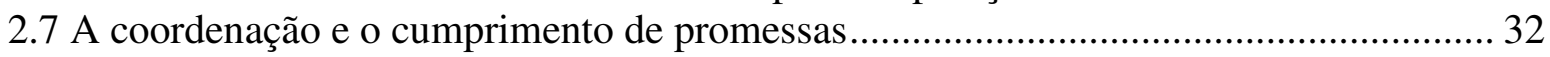

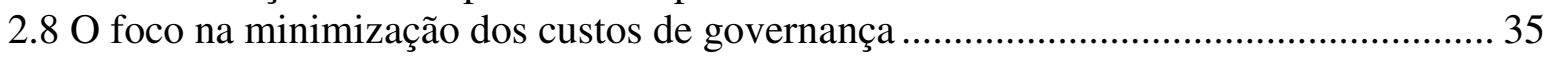

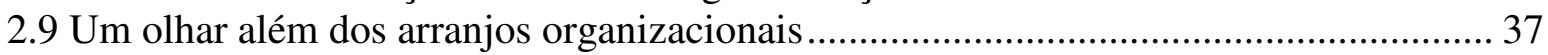

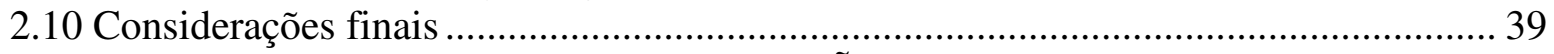

3 A ECONOMIA DOS CUSTOS DE TRANSAÇÃO E O ENRAIZAMENTO SOCIAL: UMA PROPOSTA DE INTEGRAÇÃO TEÓRICA …......................................................... 41

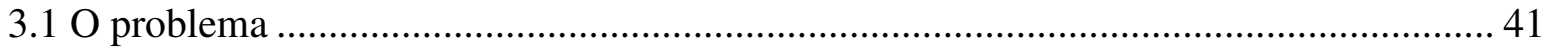

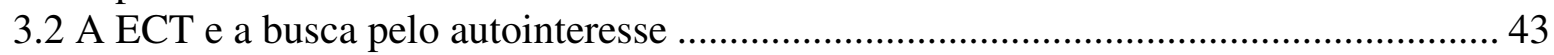

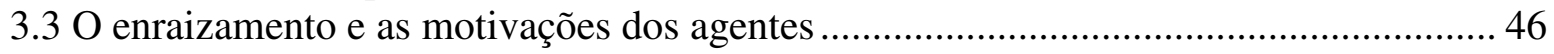

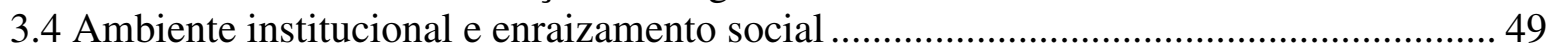

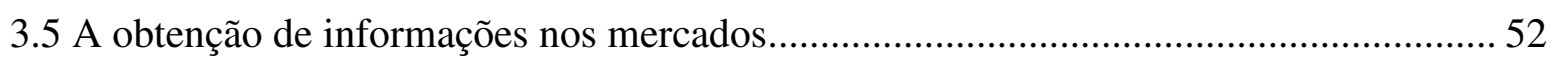

3.6 A contribuição de Block para o estudo dos mercados ................................................. 54

3.7 Os contínuos de Block e a transferência de informações ............................................... 58

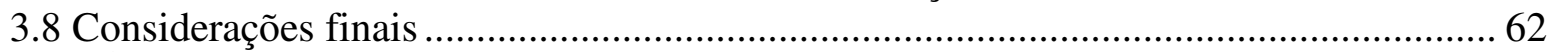

4 SERÁ A JUSTIÇA SUFICIENTE? O PAPEL DA QUALIDADE NO SISTEMA

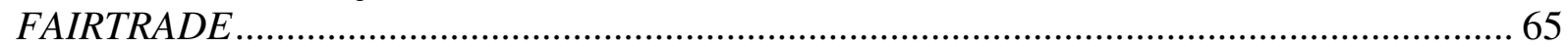

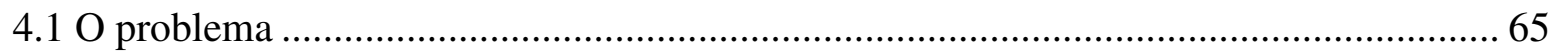

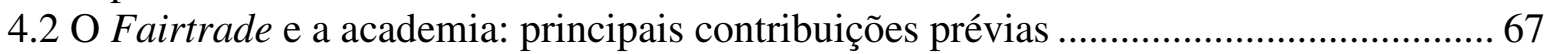

4.3 Fairtrade e a análise econômica: um falso anátema .................................................... 71

4.4 A TCM e os direitos econômicos de propriedade ......................................................... 74

$4.5 \mathrm{O}$ estabelecimento de uma certificação e o problema da inserção .................................. 78

4.6 Formas híbridas e o aumento do interesse pela cooperação .......................................... 81

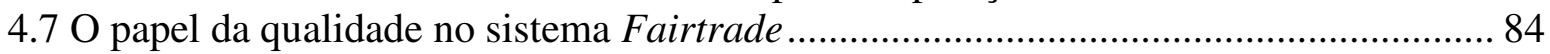

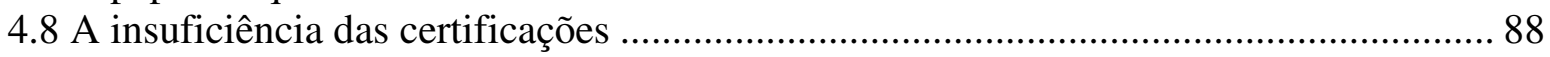

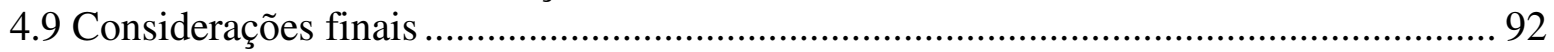

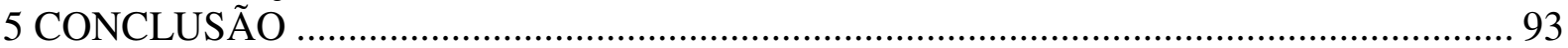

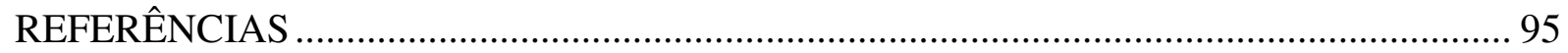




\section{INTRODUÇÃO}

\subsection{Apresentação}

A receita global da cadeia do café, em meados da década de 80 , correspondia a US\$ 30 bilhões; duas décadas mais tarde, esse total saltou para US\$ 70 bilhões (RICUPERO, 2005). Em grande medida, tal crescimento vertiginoso se deve ao reconhecimento do considerável potencial de diferenciação do setor. A exploração de novos nichos, aprofundada após o fim da Guerra Fria, tem trazido ganhos crescentes às multinacionais ligadas ao comércio do produto, além de garantir fôlego para iniciativas como a expansão das redes de cafeterias.

Todo esse crescimento, porém, não se refletiu em um aumento da receita global dos cafeicultores. De um ganho de US\$ 11 bilhões nos anos 80, os produtores passaram a receber cerca de US\$ 5,5 bilhões no princípio do século XXI. Com isso, a participação desses agricultores no total gerado pela cadeia do café caiu de $36 \%$ para cerca de $8 \%$ em vinte anos (RICUPERO, 2005). Ou seja, a dinamização do setor não se refletiu em ganhos proporcionais para a grande maioria dos envolvidos com o cultivo da matéria-prima.

As razões para a concentração de renda no setor do café vem motivando uma série de estudos desde o início do século XXI. Kaplinsky e Fitter (2004), por exemplo, enfatizam a importância da criação de atributos capazes de diferenciar um produto, de modo a evitar a concorrência baseada unicamente no preço. Nesse sentido, a emergência de novas demandas dos consumidores abriria oportunidades para a geração de rendas extraordinárias. A partir da identificação desses novos nichos, os elos da cadeia responsáveis por levar adiante um processo de diferenciação se beneficiariam de tal estratégia.

Com base em argumentos semelhantes, trabalho posterior (DAVIRON; PONTE, 2005) afirma que a criação de valor no setor do café nas últimas décadas estaria relacionada à exploração de atributos criados nos elos mais próximos dos consumidores. Mais 
especificamente, Daviron e Ponte apontam a exploração de atributos simbólicos e a diferenciação na prestação de serviços aos consumidores como as principais razões para a criação de valor no setor cafeeiro. Dessa forma, os fatores que determinariam as cotações pagas aos cafeicultores difeririam daqueles responsáveis pelo preço praticado junto ao comprador final. Estaria dada, portanto, a principal razão para a concentração da receita nos elos da cadeia dedicados a tais atividades.

Entretanto, nos moldes expostos acima, a explicação de Daviron e Ponte é incompleta. Embora identifiquem fatores centrais para a criação de valor na cadeia do café, os autores subestimam o papel das transformações ocorridas nos cafezais ao longo desse processo. Afinal, a utilização de contratos no setor aumentou consideravelmente na década de 90 (SAES; FARINA, 1999). Igualmente, a intensificação da criação de valor nessa cadeia se deu a partir da desregulamentação do mercado internacional do café, ocorrida em $1989^{1}$. Assim, aspectos relacionados ao estreitamento da coordenação entre os diversos elos do setor cafeeiro são subexplorados por Daviron e Ponte.

Em outras palavras, a melhoria da qualidade do café oferecido aos consumidores figura entre as principais razões para a criação de valor no setor. Graças à retirada de barreiras que dificultavam tal movimento ${ }^{2}$, a indústria do café passou a adotar estruturas de governança destinadas a garantir a produção desses atributos de qualidade. Nesse sentido, é justamente a aproximação entre os cafezais e os consumidores o que leva ao considerável aumento dos ganhos no setor, e não o contrário.

Inclusive, a tendência a uma maior coordenação não constitui uma particularidade da cadeia do café. Em todos os sistemas agroindustriais, a utilização de contratos tem crescido consideravelmente desde a década de 80 (ZYLBERSZTAJN, 2005b; MACDONALD et al., 2004). Nesse início de século XXI, a participação de um número crescente de produtores agrícolas no mercado se dá de forma distinta daquela demonstrada

\footnotetext{
${ }^{1}$ No Brasil, a regulamentação do mercado de café contribuiu para a queda da qualidade das colheitas. Isso se deveu ao tabelamento de preços, política que retirou qualquer incentivo para a produção de cafés especiais no país. Para um estudo acerca dos efeitos da regulamentação no mercado brasileiro de café, ver Saes (1997).

${ }^{2}$ As barreiras em questão correspondem aos Acordos Internacionais do Café (AIC). De acordo com Krasner (1973), a indústria do café dos EUA sempre evitou criticar abertamente a política de regulamentação do mercado internacional do produto, temendo confrontar os congressistas do país. Nesse sentido, foi necessário que as razões políticas para o estabelecimento do AIC desaparecessem para que o setor adotasse uma posição mais agressiva nesse tema.
} 
pelos manuais básicos de microeconomia. Dessa maneira, considerações acerca dos preços vigentes nos mercados commodities devem ser complementadas por uma análise do padrão de relacionamento originado a partir das demandas por maior coordenação.

De fato, compreender a dinâmica de inserção mercadológica dos produtores rurais constitui um importante requisito para o estudo da distribuição do valor nos sistemas agroindustriais. Indo além da tradicional discussão acerca da tendência natural de queda nos preços agrícolas frente aos ganhos de produtividade no setor (KONING; CALO; JONGENEEL, 2004), é necessário entender o que explicaria a tendência à concentração de renda mesmo quando os agricultores buscam diferenciar sua produção. Ademais, a própria heterogeneidade nos resultados obtidos por distintos grupos de produtores merece uma avaliação atenta.

O presente trabalho discute a relação entre a diferenciação na produção e a geração de renda nos sistemas agroindustriais. Dividido em três artigos, seu objetivo é apresentar uma interpretação para a dificuldade dos produtores rurais de aumentarem sua participação na renda total gerada nessas cadeias. Ao longo das próximas páginas, um aspecto do cotidiano dos agricultores será especialmente debatido, qual seja: o processo de obtenção das informações relativas aos mercados em que participam. Conforme será demonstrado a seguir, nem sempre a diferenciação sucede a plena identificação de uma oportunidade de obtenção de rendas extraordinárias.

Pelo contrário, não raramente os custos ligados à busca dessas informações são demasiado altos. Com isso, a diferenciação seria estimulada por agentes capazes de colher esses dados, e que forneceriam incentivos para o estabelecimento de uma relação cooperativa. Tendo em vista a possibilidade de adoção de estratégias oportunistas, porém, tal dependência pode abrir espaço para a ocultação parcial das informações relativas ao valor gerado a partir da especialização produtiva. Daí a tendência à concentração da renda em torno dos elos detentores dos dados acerca das demandas dos consumidores. 
A presente dissertação se encontra dividida em três artigos, dedicados a perguntas diferentes. Dessa maneira, cada uma de suas partes tem uma meta específica, ainda que estejam ligadas à preocupação com o papel da diferenciação para a geração de renda nos sistemas agroindustriais. Nos capítulos 2 e 3, a base para o debate será a chamada Economia dos Custos de Transação (ECT), resultante do trabalho de Williamson (1985, 1996). Além disso, o capítulo 3 utilizará a contribuição de autores ligados à sociologia econômica (GRANOVETTER, 1985, 2005; BLOCK, 1990), a fim de cumprir seu objetivo.

Já o capítulo 4, voltado ao estudo de um caso concreto, se baseará na Teoria dos Custos de Mensuração (TCM), derivada da obra de Barzel (1982, 1997). O exemplo discutido nesse artigo será o da certificação Fairtrade, cuja dinâmica vem motivando uma série de trabalhos (RAYNOLDS, 2002b; RENARD, 2005; JAFFEE, 2007). Devido à existência dessa literatura, o capítulo 4 discutirá também as principais interpretações dadas para o funcionamento do comércio justo. Indo além, dará sua própria versão para os eventos ocorridos no sistema Fairtrade.

Os resumos de cada artigo serão apresentados na sequência, por meio da descrição de seus objetivos específicos e problemas discutidos. Antes, porém, é importante enumerar as razões para as escolhas referentes ao ferramental teórico aqui utilizado. Conforme dito anteriormente, o presente trabalho se dedica à análise dos efeitos da diferenciação sobre a renda dos agricultores. Para tanto, levará em consideração o papel da variabilidade dos ativos na estruturação de formas alternativas de organização econômica.

De fato, o reconhecimento de que os ativos oferecidos em um mercado nem sempre são idênticos constitui um dos principais trunfos da chamada Nova Economia Institucional. Essa vertente, cujos trabalhos de Williamson e Barzel são exemplos, se dedica ao estudo dos arranjos organizacionais instituídos pelos agentes a fim de garantir a consecução de determinados resultados econômicos. Nesse sentido, os neoinstitucionalistas argumentam que o mecanismo de preços não é suficiente para a coordenação de uma série de intercâmbios. Porém, são consideráveis as diferenças entre cada uma das abordagens 
ligadas a esse grupo, sendo as interpretações dadas para o termo variabilidade uma evidência desse quadro.

Para a ECT, essa ideia está ligada à realização de investimentos específicos. Em outras palavras, a variabilidade se relaciona à posse de ativos cujo valor integral somente será obtido com a venda para um agente que os demande. Com isso, uma iniciativa visando a diferenciação produtiva levará a um estado de dependência em relação a um parceiro comercial, fato que abre a possibilidade de adoção de estratégias oportunistas (WILLIAMSON, 1985; KLEIN; CRAWFORD; ALCHIAN, 1978). Por outro lado, transações em que tais investimentos inexistam se encontram livres de qualquer problema relacionado à variabilidade dos ativos.

Já aos olhos da TCM, a variabilidade assume outro formato. A princípio, diferenças nos atributos dos ativos podem ocorrer em qualquer transação. Dito de outra forma, sua ocorrência independe da realização de investimentos idiossincráticos. Assim, a instituição de uma estrutura de governança alternativa, sob a lógica da TCM, decorre da necessidade de minimizar os custos relacionados à mensuração dos atributos dos bens transacionados. Em contraste, Williamson argumenta que a coordenação consciente visa proteger a quaserenda derivada da especialização produtiva.

Dessa maneira, o ferramental teórico utilizado em cada um dos artigos dessa dissertação está vinculado a uma ideia própria de variabilidade ${ }^{3}$. Nos capítulos 2 e 3 , é a determinação da quase-renda a principal atividade estudada, algo feito com base nos princípios da ECT. $\mathrm{Na}$ sequência, o foco passa a estar na inserção dos produtores agrícolas em mercados organizados em torno de uma certificação. Dado que a principal função desses selos é a de mensurar os atributos dos ativos transacionados, a abordagem usada na discussão empreendida no capítulo 4 corresponde àquela proporcionada pela TCM.

\footnotetext{
${ }^{3}$ É importante enfatizar que a integração entre as visões de Barzel e Williamson não figura entre os objetivos da presente dissertação. Inclusive, a existência de outras diferenças entre essas interpretações para a organização econômica, como a adoção de pressupostos comportamentais diversos, torna tal tarefa algo bastante complexo.
} 
Desde o início da década de 90, é crescente a influência da Economia dos Custos de Transação (ECT) no estudo da coordenação das cadeias agroindustriais. Inclusive, pode-se dizer que uma das principais razões para o avanço na compreensão da dinâmica em torno de tais sistemas é o florescimento dessa agenda de pesquisa. A partir de uma série de contribuições pioneiras (ZYLBERSZTAJN, 1996; MASTEN, 2000), o legado da ECT tem sido moldado ao cotidiano da agricultura, garantindo a explicação de uma série de fenômenos.

Chama a atenção, no entanto, o fato desses estudos considerarem que o estabelecimento de estruturas de governança eficientes bastaria para garantir uma divisão apropriada dos ganhos derivados da cooperação. De fato, alguns dos principais trabalhos ligados à lógica da ECT (WILLIAMSON, 1991; MENARD, 1996), assumem que a instituição de uma forma contratual híbrida, por exemplo, está associada à proteção dos ganhos individuais em uma relação. Dito de outra forma, é considerável a capacidade dos arranjos organizacionais delineados pelos agentes de mitigar os riscos relacionados à cooperação econômica.

Com isso, a preocupação das análises vinculadas à ECT se concentra na minimização dos custos de governança em uma transação econômica. Tendo em vista tal panorama, o primeiro artigo dessa dissertação discute por que as análises voltadas aos sistemas agroindustriais baseadas na ECT não consideram importante a discussão acerca da distribuição do valor criado a partir da cooperação entre os agentes econômicos? Nesse sentido, será discutida a suficiência da noção de custo de transação adotada por essa abordagem.

A partir da retomada das principais características da ECT, esse estudo buscará demonstrar que a visão dos custos de transação adotada por essa vertente desconsidera eventuais limitações existentes para a atuação dos indivíduos na esfera econômica. Em especial, salientará o fato de que nem sempre os agentes possuem todas as informações necessárias para determinar o valor exato de sua contribuição em um intercâmbio. Dessa maneira, 
estratégias oportunistas podem ser adotadas mesmo quando inexista ameaça de quebra contratual.

\subsection{O enraizamento e a trasferência de informações}

Reconhecida por sua capacidade de gerar hipóteses testáveis, a ECT tem sido criticada por ignorar aspectos relacionados ao enraizamento (embeddedness) nas relações econômicas. Granovetter (1985) argumenta que essa abordagem concede demasiada atenção às características das transações, subestimando o papel da confiança para a manutenção da ordem. Em resposta, Williamson $(1991,1993 b)$ argumenta que tal aspecto se encontra embutido nas características do ambiente institucional em que se dão os intercâmbios, de modo que determinariam os custos de governança relativos em uma sociedade.

Apesar dos esforços, a defesa de Williamson possui uma série de limitações, entre as quais a adoção de uma ideia imprecisa do enraizamento. Ao vincular tal noção ao ambiente institucional, esse autor desconsidera o argumento central de seus críticos, qual seja: as motivações dos indivíduos vão além do cálculo maximizador, sendo igualmente influenciadas pelas estruturas sociais existentes (SMELSER; SWEDBERG, 1994). Por isso, a adição de aspectos derivados à existência de enraizamento entre os agentes ao ferramental da ECT constitui uma importante tarefa a ser realizada.

Mais especificamente, o segundo artigo dessa dissertação partirá da seguinte questão inicial: De que maneira os efeitos derivados da existência de enraizamento poderiam ser apreendidos pela Economia dos Custos de Transação? Tendo em vista a inexistência de uma definição única para a noção de enraizamento (SMELSER; SWEDBERG, 1994), esse trabalho discutirá um aspecto em especial, relacionado à transferência de informações para indivíduos incapazes de obtê-las. Fundamental para o desenvolvimento do estudo em tela será o modelo apresentado por Block (1990) para a análise dos mercados.

Baseada na apresentação de dois contínuos, destinados a medir os papeis do preço e do comportamento instrumental nos mercados, a contribuição de Block fornece importantes elementos para a ampliação do espectro da ECT. A principal ideia desenvolvida nesse 
trabalho é a de que a disponibilidade de informações aos agentes constitui um dos fatores que afetariam a distribuição da renda originada da cooperação econômica. Nesse sentido, a transferência de dados indisponíveis aos parceiros em um intercâmbio constituiria um indicativo da existência de motivações mais amplas do que aquelas descritas por autores vinculados à ECT (WILLIAMSON, 1993a; KLEIN, 2002).

\subsection{Certificação e a inserção mercadológica dos cafeicultores}

A emergência de uma série de sistemas de certificação constitui uma das principais evidências da importância da diferenciação para a cafeicultura. Desde o início da década de 90 , selos dedicados a mensurar os mais variados atributos tem se consolidado, atraindo a atenção crescente dos produtores. No entanto, seu papel para a organização dos segmentos os quais pretendem atuar é incerto, sendo necessárias mais pesquisas para um dimensionamento da influência das certificações sobre o mercado internacional.

Exemplo dessa realidade é a certificação Fairtrade, concebida em torno da preocupação com o oferecimento de atributos sociais a consumidores baseados no Primeiro Mundo. Responsável por mensurar características como o caráter familiar da cafeicultura, este selo se notabiliza pelo estabelecimento de uma cotação mínima para os produtos comercializados segundo suas regras. No entanto, o excesso de oferta tem feito com que a adesão ao sistema Fairtrade seja insuficiente para garantir a inserção no segmento.

Devido à centralidade da cotação mínima na lógica de funcionamento do sistema Fairtrade, é evidente a necessidade de compreender o que leva os produtores certificados a obterem êxito nesse segmento. Afinal, a maioria da produção certificada é vendida no mercado convencional, muitas vezes por um preço abaixo daquele estipulado pelos administradores do selo. Nesse sentido, o terceiro artigo do presente trabalho parte da seguinte questão de pesquisa: o que garante a inserção das cooperativas detentoras do selo Fairtrade no mercado originado com a certificação?

Além disso, o trabalho em tela discute as razões da relativa dificuldade das principais análises dedicadas ao comércio justo de integrar aspectos teóricos e empíricos. A 
abordagem utilizada será aquela proporcionada pela Teoria dos Custos de Mensuração (TCM), resultante da contribuição de Yoram Barzel (1982, 1997, 2004). A principal vantagem da adoção de tal ferramental reside na possibilidade de discutir o selo Fairtrade a partir de uma estrutura analítica que poderia ser estendida a outros sistemas de certificação. 


\section{OS CUSTOS DE DESCOBERTA DOS PREÇOS RELEVANTES E A DISTRIBUIÇÃO DA QUASE-RENDA}

\section{$2.1 \quad$ O Problema}

Lembrado pelo caráter inovador de sua obra, Ronald Coase se notabiliza pela capacidade de explicar a origem da firma sem que, para isso, sejam ameaçadas as fundações da teoria neoclássica. Em "The Nature of the Firm", esse autor mantém a maioria dos pressupostos adotados até então, algo que explica a relativa facilidade com que a contribuição coaseana foi integrada à análise econômica. De fato, a principal novidade trazida por esse trabalho é o reconhecimento de que a utilização do mecanismo de preços não é gratuita.

Desde então, uma série de estudos tem se inspirado na contribuição de Coase. Entre as abordagens influenciadas por "The Nature of the Firm", a Economia dos Custos de Transação (ECT) ${ }^{4}$ é a que mais contribuiu para a disseminação do legado coaseano. Graças aos esforços de autores como Williamson (1985, 1996), tal vertente viabilizou a operacionalização da ideia de custos de transação, possibilitando a publicação de uma série de estudos empíricos (SHELANSKI; KLEIN, 1995; MACHER; RICHMAN, 2006).

A partir do ferramental teórico proporcionado pela ECT, diversos trabalhos vem se dedicando a analisar as transformações ocorridas nos sistemas agroindustriais ao redor do mundo (ZYLBERSZTAJN, 1996, 2005; MASTEN, 2000). Nesses estudos, a influência da contribuição teórica de Williamson é nítida, sendo notável a adoção da mesma noção de custos de transação adotada pela ECT. Com isso, tais trabalhos se caracterizam pelo foco dado à análise das estruturas de governança estabelecidas a fim de minimizar os riscos derivados do oportunismo na esfera econômica.

Por outro lado, nem todos os desdobramentos do processo de especialização produtiva são abordados por esses trabalhos. Ao demonstrar as vantagens da coordenação para a exploração de oportunidades de negócio, tais estudos consideram a distribuição dos ganhos

\footnotetext{
${ }^{4}$ A vertente originada dos trabalhos de autores como Coase e Williamson é denominada "perspectiva da governança” por Joskow (1995).
} 
derivados da cooperação um tópico bem resolvido (MENARD, 1996). Tendo em vista esse quadro, o presente artigo parte da seguinte pergunta: por que as análises voltadas aos sistemas agroindustriais baseadas na ECT não consideram importante a discussão acerca da distribuição do valor criado a partir da cooperação entre os agentes econômicos?

O principal argumento aqui desenvolvido é o de que a ECT considera de forma incompleta os efeitos dos custos de transação sobre os indivíduos. A centralização das atenções em torno de aspectos ligados ao funcionamento das estruturas de governança não tem atentado para o fato de que, muitas vezes, a incidência desses custos sobre os agentes independe da forma organizacional escolhida. Em especial, a ECT subestima os efeitos da existência dos custos de transação para a disseminação do conhecimento em uma sociedade, limitando sua atenção aos gastos referentes à governança das transações (DEMSETZ, 1993).

Por isso, é necessário um aprofundamento da ideia de custos de transação usada pela ECT, de modo a apreender todos os seus efeitos sobre os resultados econômicos colhidos pelos agentes. Afinal, assim como os mercados não se originam espontaneamente, em muitos casos as informações relevantes fornecidas por essas estruturas não chegam a todos. Tal realidade afetaria principalmente a capacidade dos agentes de determinar o tamanho da quase-renda decorrente da especialização produtiva, algo que abriria espaço para a adoção de estratégias oportunistas mesmo em relações estáveis.

\subsection{O neoinstitucionalismo econômico e a lógica da eficiência}

Qual é o sentido da organização econômica? De acordo com Alchian e Demsetz (1972), esta decorre da necessidade de mensuração da produtividade dos insumos e das recompensas correspondentes. Já para Williamson (1991), a organização econômica visa garantir a adaptação eficiente às mudanças no ambiente institucional e competitivo. Diferenças de enfoque à parte, ambas as respostas revelam importantes aspectos inerentes à vertente teórica a qual se filiam, qual seja, a Nova Economia Institucional; igualmente, fornecem elementos que explicam a relativa facilidade com que essa corrente se incorporou à análise econômica normal. 
Inclusive, é importante salientar que as proposições expressas acima não chegam a ser pioneiras ${ }^{5}$. De fato, autores como Hayek (1945) já concediam à adaptação um lugar central na categoria dos problemas econômicos, ao passo que a microeconomia neoclássica apresenta respostas para a necessidade de alinhamento entre a produtividade marginal e as recompensas destinadas aos agentes. No entanto, dizer que a contribuição de Alchian e Demsetz, ou ainda a intensa produção teórica de Williamson, reproduzem os trabalhos neoclássicos ou do economista austríaco constituiria certamente um equívoco ${ }^{6}$.

Afinal, o neoinstitucionalismo econômico, se por um lado deriva muito de sua força atual da capacidade de adequação ao ferramental marginalista (FURUBOTN; RICHTER, 2000), por outro assume, com distintos graus de ênfase, a importância da ação humana para a materialização da ordem na economia. Dessa maneira, contrasta com as tradições clássica e neoclássica, para as quais o estudo da organização no sistema econômico seria desnecessário, dada a capacidade do mecanismo de preços de garantir a alocação eficiente dos recursos (GRANOVETTER, 1985; BLOCK, 1990).

Transformar, porém, a organização econômica em um tópico relevante no imaginário dos economistas não seria possível caso as palavras viessem desacompanhadas de argumentos convincentes. No início do século XX, autores ligados às mais distintas preocupações acadêmicas apresentaram, de variadas formas, uma defesa do papel das instituições na economia, tendo recebido atenção apenas tímida de seus pares (ESPINO, 1999; FURUBOTN; RICHTER, 2000). O motivo para tal desfecho, pode-se argumentar com relativa segurança, se deveu à adoção de enfoques em que a centralidade do mecanismo de preços não era devidamente reconhecida.

Devido a esse fato, é evidente que o reconhecimento da importância das instituições para a análise econômica somente viria caso fosse capaz de se integrar ao ferramental marginalista. Prova disso é a origem do neoinstitucionalismo econômico, qual seja, a

\footnotetext{
5 Justiça seja feita, os autores supracitados reconhecem esse fato. Ver: Alchian e Demsetz (1972); Williamson, (1991).

${ }^{6}$ Da mesma forma, igualar o pensamento de Hayek à contribuição walrasiana seria um erro. Ver: Prado (1999).
} 
publicação de "The Nature of the Firm" (1937) ${ }^{7}$. Nesse artigo, Ronald Coase mantém praticamente todas as características encontradas no cenário em que a economia neoclássica se assenta, adicionando a pressuposição de que a utilização do mecanismo de preços não é gratuita. Ou seja, mais que uma ruptura com a lógica marginalista, Coase propõe uma emenda a tal paradigma.

Em outras palavras, o que o raciocínio coaseano faz é estender a lógica da eficiência a um arranjo cuja existência vinha sendo atribuída à busca por lucros extraordinários (ROBINSON, 1933; KALDOR, 1934). Ao fornecer uma explicação para a existência da firma, Coase não questiona a natureza das escolhas dos agentes econômicos, tampouco as informações levadas em conta para a tomada dessas decisões. Especificamente, o que o autor propõe é a adição de uma nova categoria de custos ao espectro analítico da microeconomia neoclássica, sendo estes derivados da utilização do mecanismo de preços ${ }^{8}$. Assim, a exemplo dos gastos decorrentes da produção, a minimização desses custos constituiria um objetivo dos agentes econômicos.

Justiça seja feita, Coase não é o primeiro a dissociar a existência da firma da busca por rendas monopolistas. De fato, a interpretação de Knight (1947), ligando a emergência dessas organizações a uma postura diferenciada por parte do empreendedor em relação ao risco, constitui um exemplo de abordagem "otimista" da firma. Entretanto, essas interpretações alternativas não foram capazes de aliar a utilização do ferramental marginalista a um problema ignorado por esta teoria, de modo que "The Nature of the Firm" é o trabalho que efetivamente abre as portas para a conciliação entre a economia neoclássica e as instituições.

Ainda assim, levaria algum tempo até que a obra de Coase fosse refinada por contribuições posteriores. Entre outros fatores, a publicação de "The Problem of the Social Cost" (1960), contribui para uma maior divulgação da contribuição coaseana, além de clarificar a viabilidade de sua incorporação à teoria marginalista. Com isso, surgem as primeiras

\footnotetext{
${ }^{7} \mathrm{O}$ texto "The Nature of the Firm" é considerado o ponto de partida para o neoinstitucionalismo econômico devido à sua influência incomparável para as ciências econômicas. No entanto, cabe lembrar que trabalhos publicados no mesmo período por autores como Commons e Barnard fornecem elementos apropriados por essa vertente teorica.

${ }^{8}$ Apesar de ser o primeiro autor a reconhecer a existência dos custos de transação, Coase não utiliza esse termo uma única vez em seu "The Nature of the Firm".
} 
definições genéricas para o termo "custos de transação", merecendo destaque duas delas: a primeira, de Stigler (1967, p. 291), para quem esta ideia estaria ligada ao "transporte da ignorância à onisciência", além daquela apresentada por Arrow (1969, p. 60), que os define como os "custos de funcionamento do sistema econômico".

No entanto, ninguém leva tão adiante o legado coaseano do que Williamson $(1985,1996)$, autor que dá o pontapé inicial para o desenvolvimento da chamada Economia dos Custos de Transação (ECT) ${ }^{9}$. Graças à capacidade de geração de hipóteses testáveis, essa vertente tem aberto caminho para a publicação de um número crescente de trabalhos empíricos (SHELANSKI; KLEIN, 1995; MACHER; RICHMAN, 2006). Da mesma maneira, a consolidação da ECT confirma a tendência de convergência entre o neoinstitucionalismo econômico e os princípios da microeconomia neoclássica (RIORDAN; WILLIAMSON, 1985).

Nesse sentido, o grande mérito da ECT reside na instrumentalização da ideia de que a realização de transações não é gratuita, ainda que às custas de um achatamento do raciocínio de Coase. Em especial, chama a atenção a relevância que uma variável, a especificidade dos ativos, adquiriu para uma contribuição que a princípio se mostrava mais ampla $^{10}$. O aspecto mais importante da abordagem coaseana, porém, é mantido por Williamson, para quem a organização econômica visa garantir a eficiência nos intercâmbios.

\footnotetext{
${ }^{9}$ Apesar de Williamson ser o principal responsável pela formatação da Economia dos Custos de Transação, a contribuição de outros autores não pode ser esquecida. Diversos trabalhos inspiraram o desenvolvimento dessa vertente, especialmente aquele escrito por Klein, Crawford e Alchian (1978).

${ }^{10}$ Da mesma maneira, vale lembrar que Williamson (1985) adota pressupostos comportamentais distintos daqueles considerados por Coase em sua discussão acerca da natureza da firma, quais sejam: o oportunismo e a racionalidade limitada. Em relação a esse último pressuposto, é evidente que Coase não o poderia utilizar, dado que a ideia da racionalidade limitada (SIMON, 1955) só é trazida ao debate econômico cerca de duas décadas após a publicação de "The Nature of the Firm". Já o oportunismo é fruto do reconhecimento da existência de variabilidade entre os ativos, algo que Coase tampouco faz.
} 
Graças à sua habilidade de introduzir o problema da organização em um arcabouço teórico que outrora o ignorava, Coase garantiu a longevidade do neoinstitucionalismo econômico. Sua proposta, baseada na adição de uma nova categoria de custos ao espectro analítico da microeconomia neoclássica, progressivamente ganhou a aceitação da academia, garantindo o renascimento do interesse pelo estudo das instituições entre os economistas.

De fato, nem mesmo a inexistência de uma definição precisa para o termo "custos de transação" foi capaz de frear esse movimento. Para tanto, foi fundamental a identificação das principais consequências derivadas da adição dessa noção aos modelos econômicos. Nesse sentido, pode-se dizer que, além de representarem um tipo de gasto distinto daquele tradicionalmente considerado pela teoria neoclássica, os custos de transação se relacionam, de diferentes maneiras, à busca por informações e seu processamento.

Em relação à primeira regularidade identificada acima, são variadas as tentativas de quantificar os custos de transação (LOADER, 1995; FURUBOTN; RICHTER, 2000), ainda que estas estejam sujeitas a uma série de limitações. Inclusive, Williamson (1991) defende a tese de que a determinação precisa desses custos não constitui um requisito para os estudos dedicados à organização econômica, haja vista o alcance da análise discreta comparada para tal objetivo. Já a natureza informacional dos custos de transação tem motivado as mais diversas interpretações, cada qual dedicada a um foco específico ${ }^{11}$.

Diferenças à parte, todas essas abordagens tratam da relação entre a existência dos custos de transação e a alocação dos recursos. No mundo considerado pelo neoinstitucionalismo econômico, a introdução de restrições ignoradas pela teoria neoclássica impõe a necessidade de um redimensionamento da atuação humana nos mercados. Assim, o estudo da organização econômica constitui, essencialmente, uma avaliação dos limites do mecanismo de preços para a coordenação das transações.

\footnotetext{
11 Barzel $(1982,1997)$ apresenta uma abordagem alternativa para esse tema. Para uma apresentação comparada das visões de Williamson e Barzel, ver Zylbersztajn (2005a).
} 
É vital salientar, porém, que a Nova Economia Institucional não questiona a importância do mecanismo de preços para a alocação de recursos. Nesse sentido, o planejamento empreendido pelos humanos visa, em casos específicos, permitir uma minimização dos custos derivados da atividade econômica. Destituídos de sua função coordenadora quando conveniente, os preços seguem fornecendo informações fundamentais para a organização da produção, sendo incontestável a sua influência na questão alocativa.

Um bom exemplo dessa realidade é a firma coaseana. Resultado da busca por maior eficiência, esse arranjo visa à minimização dos custos ligados à atividade econômica sem que, para isso, a lógica do mecanismo de preços seja subvertida. Ora, no mundo coaseano, todos os agentes tem pleno acesso ao mecanismo de preços, podendo obter a informação para a realização dos intercâmbios sempre que necessário. Evidentemente, conseguir esses dados custa, e em alguns casos, muito. Por isso, Coase (1937) aponta o processo de descoberta dos preços relevantes como uma das fontes de custos decorrentes da utilização do mercado.

Em "The Nature of the Firm", Coase não chega a se aprofundar na discussão das possíveis formas de minimizar esses custos derivados da descoberta dos preços relevantes. De acordo com Cheung (1983), obter essa informação acarretaria gastos principalmente por parte dos consumidores, que teriam dificuldade de mensurar e recompensar cada um dos responsáveis pela fabricação dos componentes de um ativo. Implicitamente, Cheung assume que os responsáveis pela produção de um determinado bem possuem a melhor informação disponível acerca do valor de sua contribuição.

Nesse sentido, o estabelecimento da firma garantiria que os dados necessários para a precificação de um bem fossem compilados pelos responsáveis pela produção. Entretanto, a descoberta dos preços relevantes constitui uma atividade relacionada não apenas aos consumidores, como aos próprios detentores dos ativos transacionados. Por se tratar de um gasto relacionado à busca por informação, o mesmo independeria, sob um ponto de vista individual, da forma organizacional escolhida. Afinal, tal atividade está ligada ao acesso que cada pessoa possui à informação necessária para a realização de uma transação, ou seja, os $\operatorname{preços}^{12}$.

\footnotetext{
${ }^{12}$ Assim como a maioria dos economistas, Coase trabalha com a pressuposição de que o mundo é composto por agentes atomizados. Para uma discussão acerca desse tópico, ver: Granovetter (1985).
} 
$\mathrm{Na}$ firma coaseana, é de se esperar que a minimização dessa categoria de custos se dê por meio da concessão da prerrogativa de buscar os preços relevantes àquele que possa fazê-lo da forma mais eficiente. No entanto, o agente responsável por tal atividade não faria mais que transformar os sinais dados pelo mecanismo de preços em ordens e pagamentos aos insumos contratados, haja vista o fato de que a informação relevante se encontra acessível a todos ${ }^{13}$. Dito de outra forma, qualquer trapaça empreendida pelo coordenador dessa organização poderia ser verificada por seus parceiros, ainda que por meio do dispêndio de recursos.

Obviamente, o mero reconhecimento da existência de custos para a descoberta dos preços relevantes seria incapaz de justificar um arranjo como a firma. Devido à impossibilidade de adoção de estratégias oportunistas na divulgação dessas informações, os agentes poderiam combinar formas de cooperação que não envolvessem necessariamente a organização interna da produção. Talvez por isso, Coase (1937) concentre suas atenções em outra fonte de gastos ligada ao uso do mercado identificada em seu trabalho, qual seja: o processo de negociação e conclusão contratual ${ }^{14}$.

Não por acaso, a firma coaseana consiste na celebração de um único acordo de longo prazo em substituição às repetidas negociações necessárias em uma economia coordenada pelo mecanismo de preços. Inclusive, a ênfase de Coase na natureza contratual da firma se explica pelo evidente papel da escolha organizacional na minimização dessa categoria de custos. No entanto, a preocupação do autor em relação a esse tópico, ao que parece, se limita aos recursos gastos pelas partes como consequência da celebração de sucessivos $\operatorname{contratos}^{15}$.

\footnotetext{
${ }^{13}$ É importante lembrar que Coase não apresenta os motivos que determinariam o agente responsável pela direção da firma (ALCHIAN; DEMSETZ, 1972), apesar de considerar essa decisão fundamental. Dessa maneira, a interpretação apresentada acima nada mais é do que uma tentativa de compreender a busca pela minimização dos gastos de utilização do mecanismo de preços no mundo coaseano.

${ }^{14}$ Ainda que essa variável tampouco seja suficiente para explicar a emergência da firma no mundo coaseano. Afinal, se os custos relativos à negociação contratual fossem os únicos passíveis de minimização, a tendência seria de constituição de uma única firma. Daí a necessidade de compreender as atividades realizadas no interior dessa organização, e que evidentemente acarretam gastos aos agentes.

${ }^{15}$ Evidência disso é a referência feita por Coase (1937, p. 391) a texto de Usher, para quem "[...] the sucessive buying and selling of partly finished products were sheer waste of energy".
} 
Décadas mais tarde, Coase (1960) retoma o aspecto informacional dos custos de transação em seu "The Problem of the Social Cost". Nesse trabalho, o autor demonstra que o Estado não constitui necessariamente a alternativa mais eficiente para a alocação de direitos em casos os quais haja conflito de interesse entre as partes. Entre outras razões, tal conclusão se deve ao fato de que o fornecimento de um veredicto por parte do judiciário não é gratuita. Pelo contrário, em muitos casos os agentes seriam capazes de fornecer uma resposta mais eficiente do que aquela oferecida pelo Estado, sendo um melhor acesso à informação relevante o principal motivo desse desfecho.

Assim como em "The Nature of the Firm", a eficiência a qual Coase se refere em sua análise da administração das externalidades está relacionada à minimização dos custos decorrentes da utilização do mecanismo de preços. Nesse sentido, o autor mantém a pressuposição de que a capacidade de verificação dos preços relevantes se encontra aberta a todos os agentes. De fato, Coase demonstra que decisões judiciais desrespeitosas aos sinais do mecanismo de preços seriam revertidas caso a realização de transações de mercado fosse gratuita. O que impediria, dessa forma, a correção alocativa desses veridictos seria a existência de custos de negociação e conclusão contratual proibitivos.

\subsection{A ECT e a garantia dos investimentos específicos}

Denominados "custos de utilização do mecanismo de preços", os gastos ligados à realização de transações são originalmente divididos por Coase (1937) em: (1) aqueles ligados à descoberta dos preços relevantes e (2) custos derivados da negociação e conclusão contratual. Conforme visto até aqui, o reconhecimento da existência dessas restrições à atividade econômica fundamenta a interpretação da firma como um arranjo eficiente, tornando possível a legitimação da organização consciente com base no ferramental marginalista.

Dessa maneira, a abordagem dos custos de transação nos moldes propostos por Coase carrega implicitamente uma série de pressupostos cuja manutenção tem se mostrado providencial para a aceitação do neoinstitucionalismo econômico. Em especial, chama a atenção o fato de que, no mundo coaseano, todos os indivíduos tem acesso ao mecanismo 
de preços, ainda que a um custo variado. Assim, questões de cunho distributivo são insignificantes, dado que cada agente recebe exatamente aquilo que lhe cabe nesse cenário hipotético $^{16}$.

De fato, a discussão acerca da dinâmica do processo de descoberta dos preços relevantes tem sido apenas marginal entre os neoinstitucionalistas. Seguindo a tendência de Coase, os principais autores dedicados ao estudo da organização econômica enfatizam os custos relacionados à atividade contratual em sua interpretação das ações dos indivíduos. Aspectos informacionais, apesar de considerados, assumem uma roupagem diferente nessas abordagens, decorrendo exclusivamente do quadro de dependência criado a partir do estabelecimento de uma relação entre os agentes.

Em grande parte, o aprofundamento dessa visão se deve ao trabalho de Klein, Crawford e Alchian (1978). Nele, a interpretação para a existência da firma se encontra relacionada a um caso específico, qual seja: a realização de investimentos idiossincráticos. Nesse sentido, o trio supracitado argumenta que a integração vertical emergiria como uma resposta ao risco de expopriação da quase-renda derivada da posse de um ativo cujas características fossem integralmente valorizadas por apenas um parceiro comercial.

Apesar de fazerem referência ao legado coaseano, Klein e seus colegas buscam demonstrar que a decisão de instituir uma firma, indo além daquilo que "The Nature of the Firm" prescreve, não se deve apenas ao desejo de minimizar os gastos de negociação e conclusão contratual. Inclusive, esses autores argumentam que os custos derivados da garantia dos acordos formais podem ser até mais importantes que aqueles ligados à sua redação. Consequentemente, o trio se limita à discussão das ações dedicadas a verificar o cumprimento dos contratos.

Isso não significa que Klein, Crawford e Alchian não reconheçam outros gastos além daqueles relacionados ao enforcement contratual. $\mathrm{Na}$ realidade, os autores apontam a existência de custos de informação e transação para a obtenção dos acordos,

\footnotetext{
${ }^{16}$ A noção de eficiência usada na economia decorre dos estudos de Pareto (1987), cuja preocupação central reside na alocação dos recursos. Dessa forma, a equidade na distribuição da riqueza não constitui uma prioridade do ponto de vista analítico. No entanto, sob essa lógica cada agente recebe exatamente aquilo que lhe corresponde de acordo com a dotação inicial de recursos, dado que todos conhecem os termos de troca dos ativos possuídos.
} 
especificando-os como resultantes dos esforços de descoberta dos custos e da receita real, além das discussões acerca da divisão dos lucros. Entretanto, eventuais esforços de minimização desses custos não são abordados ao longo do trabalho, resultado do foco definido pelos autores ${ }^{17}$.

Na década seguinte, Williamson (1985) apresenta sua própria definição para os custos de transação, aprofundando as opçãos teóricas feitas por Klein, Crawford e Alchian. Segundo o autor, estes consistiriam nos custos ex-ante de preparar, negociar e salvaguardar os acordos formais, além dos custos ex-post ligados à adaptação da relação contratual em caso de eventos inesperados. Com isso, enfoca ainda mais a preocupação com a proteção de investimentos idiossincráticos como razão central para a organização econômica consciente.

Sob a lógica proposta por Williamson $(1985,1991)$, tanto os custos de transação ex-ante como os ex-post estão ligados ao processo de escolha e readequação de uma forma contratual, de modo que sua existência deriva do estabelecimento de uma estrutura de governança. A exemplo de Coase (1960), o autor demonstra que nem mesmo o funcionamento do mercado é gratuito, dado que essa opção exige a instituição de contratos e a concessão de garantias por parte do judiciário.

Ainda assim, o mercado segue sendo a forma organizacional menos custosa para a realização de grande parte das transações. Afinal, a existência de custos burocráticos ligados à instituição de uma firma torna essa opção uma espécie de último recurso, utilizada somente quando seja mais eficiente (WILLIAMSON, 1991). Para a ECT, porém, o cálculo das vantagens para a organização interna da produção é mais complexo do que aquele presente na abordagem coaseana.

\footnotetext{
${ }^{17}$ É possível afirmar que, nos exemplos apresentados, Klein, Crawford e Alchian consideravam resolvidos eventuais problemas informacionais ligados à negociação contratual. Ou seja, os agentes envolvidos nas relações analisadas teriam exato conhecimento daquilo que perderiam caso o acordo fosse rompido. Inclusive, estudos posteriores adotam uma lógica semelhante. Ver: Klein (2002).
} 
Afinal, no mundo descrito por Williamson (1985), o reconhecimento da variabilidade ${ }^{18}$ entre os ativos aliado à adoção de pressupostos comportamentais diferenciados abre uma série de novos desafios aos agentes. Mais especificamente, a ECT assume que os indivíduos são dotados de racionalidade limitada, sendo portanto incapazes de redigir contratos completos, além de poderem agir de forma oportunista (WILLIAMSON, 1985, 1993b). Com isso, a mera comparação entre custos relativos de governança seria insuficiente para descrever as escolhas institucionais nesse cenário.

De fato, sob a lógica da ECT, a adoção de uma estrutura de governança alternativa se deve à incapacidade do mecanismo de preços de garantir a alocação eficiente dos recursos. No entanto, isso não se deve à insuficiência das informações fornecidas por esse sistema. Ora, não há nada mais que o mecanismo de preços possa dar às partes além do preço. Dessa forma, o que impediria a conformação de um quadro eficiente nesse caso seria a falta de garantias para a realização de investimentos idiossincráticos.

Em outras palavras, o mercado é incapaz de fornecer alternativas para a comercialização de ativos específicos em caso de quebra de compromisso. Assim, a adoção de uma estratégia oportunista por parte do responsável pela compra desse ativo levaria à captura de uma parcela da quase-renda derivada desse investimento idiossincrático (KLEIN; CRAWFORD; ALCHIAN, 1978). Por isso, o temor relacionado ao risco de quebra contratual faria com que os agentes evitassem tais ações, a menos que uma forma organizacional específica o possibilitasse.

Nesse sentido, a busca pela coordenação consciente ocorrerá sempre que determinada oportunidade de criação de valor dependa de garantias de cooperação mútua. Implicitamente, a ECT assume que a estrutura de governança mais adequada para determinado intercâmbio será aquela que garanta a melhor alocação possível para os insumos transacionados, viabilizando a realização dos investimentos necessários para a maximização do valor potencial da relação ${ }^{19}$.

\footnotetext{
${ }^{18}$ A variabilidade entre os ativos, nesse caso, é uma consequência da realização de investimentos específicos a fim de oferecer algo demandado por um parceiro comercial. Dessa forma, não se confunde com o tratamento que Barzel (1982) dá para esse termo.

${ }^{19}$ Ou seja, a preocupação dos agentes vai além da minimização dos custos relacionados à governança das transações. Afinal, a maximização do valor envolvido em uma transação faz parte do cálculo dos agentes no momento de decisão pelo uso de uma estrutura de governança.
} 
Dessa maneira, Williamson (1985) se mantém fiel à tradição do neoinstitucionalismo, conservando a importância do mecanismo de preços para o direcionamento das atividades econômicas. Tanto isso é verdade que o autor cita a definição de custos de transação dada por Arrow (1969), demonstrando que o funcionamento do sistema econômico, apesar de não ser gratuito, é uma constante. Ou seja, a limitação do papel do mecanismo de preços estaria ligada à sua incapacidade de coordenação exclusiva do sistema econômico.

No entanto, a garantia dos direitos sobre os investimentos não basta. Daí a busca por uma forma organizacional que minimize os custos de transação envolvidos em um intercâmbio. $\mathrm{Na}$ visão da ECT, a estrutura de governança mais adequada é aquela que garante a maximização do valor global derivado da cooperação ao mesmo tempo que assegura o menor gasto possível de recursos. Assim como para Coase, contratar custa caro para Williamson, e pior, não garante o sossego das partes no longo prazo.

Justamente por isso, a minimização dos custos de transação ex-ante está relacionada à escolha de uma estrutura contratual adequada, ainda que incapaz de prever todas as contingências futuras (WILLIAMSON, 1985, 1991). De fato, a adoção de pressupostos comportamentais diferenciados por parte da ECT visa justamente enfatizar o problema da contratação incompleta. Um arranjo eficiente seria, então, aquele capaz de garantir a economia em racionalidade limitada, evitando gastos excessivos na estruturação de cláusulas contratuais inúteis.

Além disso, a estrutura escolhida deve ser capaz de garantir a resolução dos problemas no momento em que eles surjam, obtendo soluções às custas do menor dispêndio de recursos possível. Com isso, a minimização dos custos de transação de natureza ex-post estaria igualmente ligada à instituição de uma forma organizacional específica. Portanto, para Williamson (1985) a análise das transações é suficiente para a compreensão dos determinantes da adoção de uma estrutura de governança. Eventuais restrições impostas pelos custos de transação sobre os agentes são ignoradas pela ECT. 


\subsection{Investimentos idiossincráticos e a determinação da quase-renda}

Mercados são construções sociais, sendo sua existência o resultado direto da interação entre os humanos. Tal fato, entretanto, vem sendo negligenciado pela teoria neoclássica, usuária de uma concepção abstrata dessas estruturas (ABRAMOVAY, 2004). Devido ao foco dado à análise de temas como a formação de preços e a alocação de recursos, a maioria dos economistas não chega a se preocupar com o processo de construção dos mercados. Inclusive, a falta de interesse por este tópico levou à consolidação de um pressuposto irreal, qual seja, o de que tais estruturas funcionam gratuitamente.

Coube à Coase (1960) a tarefa de demonstrar que os aparatos burocráticos precisam de recursos para funcionar. Entretanto, a reação dos economistas frente à contribuição coaseana foi a de enumerar as limitações do judiciário para a resolução de controvérsias, sendo mantido o baixo interesse pela origem dos mercados. Apesar de reconhecer a existência de custos de governança relacionados ao funcionamento dessas estruturas, a ECT não chega a discutir as implicações de tal constatação. Dessa maneira, a abordagem de Williamson mantém a concepção abstrata de mercado adotada pelos neoclássicos.

Em outras palavras, a ECT considera que os agentes teriam condições de obter todas as informações necessárias para sua atuação na esfera econômica. Tais dados seriam disponibilizados pelo mecanismo de preços, que funcionaria de maneira perfeita dentro de sua única prerrogativa, qual seja, fornecer os preços. Com base nessas informações, os agentes decidiriam o que fazer segundo um cálculo maximizador (KLEIN, 2002). Já o eventual estabelecimento de estruturas de governança alternativas, por representar uma ação necessariamente mais custosa que o uso do mercado, seria reservado a situações especiais.

No entanto, mercados não se originam espontaneamente. De fato, tais estruturas se encontram amparadas em regras determinadas por uma autoridade, e que refletem as preferências dos grupos de interesse existentes em uma sociedade (FLIGSTEIN, 1996). Em especial, a emergência dos Estados constitui um elemento que viabilizou a existência de mercados. Da mesma forma, o mecanismo de preços não é uma entidade que irradia 
suas informações a todos os indivíduos, sendo necessária a instituição de aparatos específicos para o fornecimento desses dados.

Por exemplo, o estabelecimento de organizações como as bolsas de valores permite o processamento de grande quantidade de informações a um custo individual relativamente baixo. Graças à instituição de um aparato burocrático considerável, tais dados são disponibilizados aos agentes interessados, algo que garante resultados próximos daqueles previstos pela análise neoclássica. Tal realidade, porém, se deve não apenas à existência de uma estrutura capaz de viabilizar a interação humana. Além disso, o número de participantes em um mercado contribui diretamente para a determinação do custo individual de obtenção das informações relevantes.

Quando Cheung (1983) afirma que a existência da firma se deve à dificuldade dos consumidores de mensurar e recompensar os responsáveis pela produção dos vários componentes em um ativo, é pressuposto que os últimos tem plena noção daquilo que devem receber ${ }^{20}$. Porém, o problema em questão possui uma natureza recíproca, ou seja, as limitações relacionadas à obtenção de informações no sistema econômico afetam todos os agentes. Sendo resultado da busca pessoal ou da instituição de arranjos organizacionais alternativos, a posse de tais dados acarreta custos consideráveis, e que, consequentemente, podem ser proibitivos a muitos indivíduos.

Afinal, o estabelecimento de um grande aparato burocrático voltado a fornecer as informações relevantes só é possível quando um número considerável de indivíduos demanda tal ação, dividindo seus custos de manutenção. Dessa maneira, a realização de investimentos idiossincráticos, ao contribuir para a diminuição do número de interessados nos ativos produzidos, torna inviável a constituição de estruturas como uma bolsa de valores, por exemplo. $\mathrm{O}$ resultado de tal movimento, conforme a figura 1 demonstra, é o aumento dos custos individuais de obtenção das informações relevantes a medida que os agentes passam a transacionar bens com um grau não trivial de especificidade.

\footnotetext{
${ }^{20}$ Para uma crítica semelhante, ver Demsetz (1993).
} 


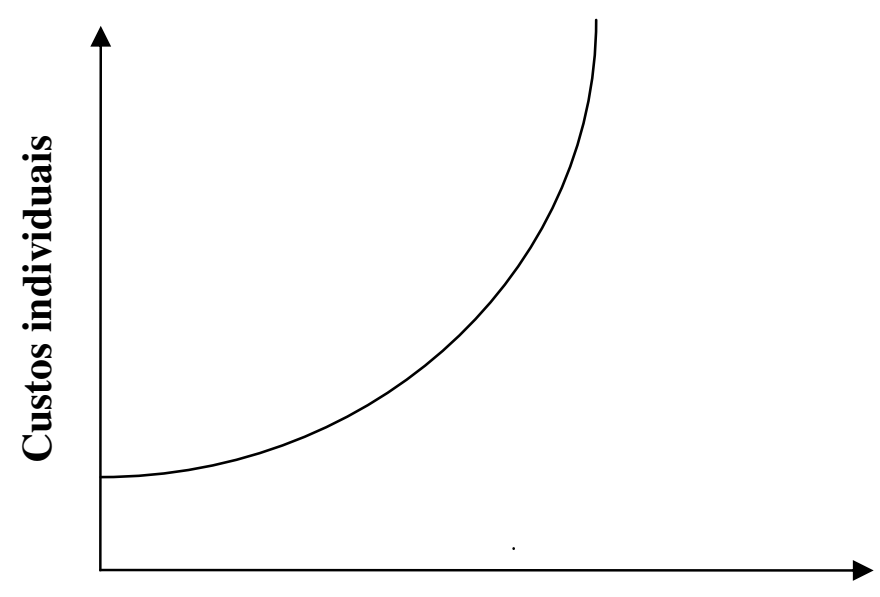

Especificidade dos ativos $(k)$

Figura 1: Custos individuais de obtenção das informações acerca dos preços relevantes

Assim, a adoção de uma ideia abstrata dos mercados leva a ECT a desconsiderar alguns desdobramentos do cenário o qual se propõe a analisar. A realização de investimentos específicos, se por um lado origina uma quase-renda decorrente da especialização produtiva, por outro exige esforços por parte dos agentes para seu dimensionamento. Ora, o conhecimento daquilo que os consumidores aceitariam pagar por tais atividades, requisito incontornável para tal cálculo, não é automático ${ }^{21}$. Dessa forma, identificar as recompensas relacionadas a uma contribuição específica exige o dispêndio de recursos.

A desconsideração ao problema aqui exposto contribui para que a ECT adote uma visão particular da cooperação econômica. Nela, os mecanismos de governança são suficientes para a resolução das principais dificuldades no relacionamento entre os agentes (GRANOVETTER, 1985), dado que os indivíduos não possuem qualquer limitação relacionada à sua atuação nessa esfera. Não por acaso, os estudos ligados à ECT tendem a privilegiar aspectos ligados à minimização dos custos de governança, vistos como uma espécie de garantia para agentes que sabem exatamente o que está em jogo. A apresentação dessa visão constituirá o objetivo das próximas seções desse trabalho.

\footnotetext{
${ }^{21}$ Segundo Hayek (1996), a análise walrasiana se equivoca ao não considerar o problema fundamental da dispersão do conhecimento no sistema econômico. Nesse sentido, o autor defende que essa abordagem não leva em consideração o fato de que os indivíduos possuem porções distintas de conhecimento, de modo que a interação humana é a principal responsável pela auto-organização dos mercados.
} 


\subsection{Formas híbridas e o aumento do interesse pela cooperação}

A definição de conceitos constitui uma das principais dificuldades envolvidas no trabalho dos cientistas sociais. Exemplo claro disso é o debate acerca do significado do termo firma: reconhecida a importância de seu estudo, qual tipo de arranjo mereceria, afinal, tal denominação? A resposta para tal pergunta certamente é das mais difíceis. Inclusive, Alchian e Demsetz (1972) chamam a atenção para a insuficiência inerente a qualquer interpretação da firma que reivindique para si a capacidade de explicar a totalidade de casos rotineiramente associados a esse termo.

É justamente devido a essa dificuldade que Klein, Crawford e Alchian (1978) afirmam ser mais útil analisar cada arranjo contratual de acordo com a situação particular em que se insira, sendo a firma apenas uma forma entre muitas possíveis. De fato, a realidade mostra que a riqueza de estruturas existentes é bastante superior ao tradicional dilema "fazer ou comprar". Ainda que a força das interpretações baseadas no aspecto contratual da firma seja inegável (CHEUNG, 1983; COASE, 1937), é fundamental enfatizar que nem todo contrato resulta necessariamente em uma integração vertical.

Nesse sentido, Williamson (1991) alerta para a insuficiência daquelas visões que equivalem a firma a um nexo de contratos (ALCHIAN; DEMSETZ, 1972; COASE, 1937). Indo além, a ECT associa cada estrutura de governança genérica a modos de coordenação e controle específicos, cujas características resultariam em habilidades particulares para a adaptação (WILLIAMSON, 1991, 1996). Mais especificamente, as diversas formas organizacionais existentes estão ligadas a mecanismos de resolução de controversias e geração de incentivos próprios, delineados de acordo com as características das transações.

Com isso, a firma se caracterizaria por sua capacidade de autorregulação. Em outras palavras, a prerrogativa de julgar disputas internas constituiria o principal diferencial dessa estrutura de governança em relação a outras formas de organização da produção (WILLIAMSON, 1991). O estabelecimento de tal aparato, no entanto, não estaria livre de dilemas. Afinal, a manutenção dessa estrutura burocrática acarreta custos consideráveis aos agentes, de modo que sua instituição somente se daria caso a criação de valor resultante o justificasse. 
Além disso, a organização econômica por meio da firma carrega a desvantagem de não fornecer incentivos tão poderosos para a devida recompensa à produtividade dos insumos. Em outras palavras, a estruturação de equipes em torno de uma hierarquia pode abrir brechas para que os agentes diminuam seu esforço produtivo, uma vez que sua relação com o mecanismo de preços é apenas indireta (WILLIAMSON, 1991; ALCHIAN; DEMSETZ, 1972). Como resultado, a maximização do produto derivado da cooperação estaria seriamente ameaçada.

Dessa maneira, a opção pela integração vertical constitui uma espécie de último recurso (WILLIAMSON, 1991), resultado da incapacidade do mercado de garantir alternativas para a comercialização de ativos com alto grau de especificidade. Afinal, a utilização exclusiva do mecanismo de preços como instrumento para a coordenação e controle da atividade econômica tampouco está livre de riscos. Principalmente na presença de investimentos idiossincráticos, tal estrutura é incapaz de garantir a proteção aos agentes contra o oportunismo, impedindo a adaptação eficiente.

Muitas transações, porém, são organizadas por meio de estruturas de governança intermediárias, cujas características não se enquadrariam em nenhum dos casos descritos acima. De fato, em muitos casos os indivíduos optarão pela adoção de formas organizacionais menos custosas, como as chamadas formas híbridas (WILLIAMSON, 1991; MENARD, 1996). Nelas, a existência de ativos com um grau não trivial de especificidade contrasta com a manutenção da autonomia entre as partes. Desse modo, o imperativo da coordenação deve ser forjado em um contexto marcado pela ausência de hierarquia.

Assim, tal estrutura de governança deve garantir a proteção aos investimentos especializados envolvidos na relação sem que, para isso, seja necessário o estabelecimento de um aparato burocrático para a resolução de controversias. Tendo em vista esse quadro, a forma prescrita pela ECT para a governança das formas híbridas corresponde à adoção de um contrato do tipo neoclássico (WILLIAMSON, 1991; MACNEIL, 1978), cuja 
flexibilidade busca garantir a margem necessária para as adaptações inevitáveis ao longo do tempo ${ }^{22}$.

Essa capacidade de acomodação, fundamental em um híbrido, decorre da importância da identidade das partes para o êxito da transação. Ao contrário daquilo que se observa em uma transação de mercado típica, o rompimento de uma relação dessa natureza traz enormes prejuízos a todos. Afinal, somado ao valor destruído decorrente da não utilização de ativos especializados, o efeito negativo sobre a reputação dos agentes poder ser considerável. Daí a importância de que a relação seja capaz de se adaptar de forma eficiente frente a turbulências administráveis.

Isso posto, uma questão pendente diz respeito à forma como a adaptação seria garantida em um híbrido. Embora não chegue ao extremo da integração vertical, uma forma híbrida igualmente necessita algum tipo de coordenação consciente, algo que o mercado não é capaz de fornecer. Por outro lado, a emergência de um coordenador nesses arranjos somente se justificaria caso algum argumento baseado na lógica da eficiência estivesse disponível.

Em grande medida, o debate acerca da determinação do líder em uma forma híbrida se assemelha àquele levantado no exemplo da firma coaseana. Dada a ausência de hierarquia em ambos os arranjos, as decisões voltadas a conduzir um híbrido deveriam se originar naquele ponto em que a obtenção das informações relevantes fosse obtida de forma mais eficiente. Nesse sentido, Menard (1996) defende que a coordenação eficiente dos híbridos é possível graças a um modo específico de adaptação, baseado na autoridade.

Ao contrário da hierarquia, típico das organizações formais, esse princípio se baseia na delegação da capacidade de decidir. Assim, a concessão da autoridade a determinado agente constituiria uma decisão reversível a qualquer momento. Além disso, a perenidade de tal ato dependeria da consolidação de uma relação baseada na confiança, ou ainda na capacidade de convencimento dessa liderança com base em argumentos factíveis (MENARD, 1996). Dito de outra forma, a legitimidade do coordenador em uma forma

\footnotetext{
22 Entre outras características, o contrato neoclássico garante o estabelecimento de zonas de tolerância, dentro das quais falhas no alinhamento entre as partes poderiam ser absorvidas, além da requisição de que as informações sejam reveladas quando necessário. Para maiores detalhes, ver Williamson (1991).
} 
híbrida estaria ligada ao reconhecimento de sua maior competência para garantir a maximização do valor gerado por esse arranjo.

Consequentemente, o estabelecimento de um consenso acerca da melhor liderança depende da capacidade de auto-avaliação dos custos individuais de verificação das informações relevantes. Para tanto, o acesso ao mecanismo de preços deve estar disponível a todos. Sob a lógica da ECT, portanto, o coordenador de uma forma híbrida apenas transformaria os sinais do mecanismo de preços em indicações, sendo a possibilidade de checagem de seus parceiros a principal garantia contra trapaças.

\subsection{A coordenação e o cumprimento das promessas}

Graças ao reconhecimento da importância das formas híbridas, a literatura dedicada ao estudo da coordenação na esfera econômica tem crescido consideravelmente desde o início dos anos 90. Inspirados no desenvolvimento teórico empreendido após a introdução dos custos de transação à análise dos mercados, esses estudos (MENARD, 1996; ZYLBERSZTAJN, 1996; BOGETOFT; OLESEN, 2004) vem contribuindo para a consolidação de uma visão dessas estruturas de governança bastante próxima daquela apresentada pela ECT.

Com isso, a interpretação de Williamson para o fenômeno da organização consciente tem contribuido para que os trabalhos dedicados à cooperação na esfera econômica se dediquem a um conjunto de problemas bastante específico. Aspectos relacionados à minimização dos custos derivados do funcionamento dessas estruturas de governança constituem o principal foco desses estudos, ao passo que as características individuais dos agentes envolvidos nos intercâmbios são praticamente ignoradas.

De fato, Williamson (1985) considera o oportunismo e uma interpretação própria da racionalidade limitada pressupostos comportamentais suficientes para a análise da organização econômica. Dessa maneira, a ECT lida com agentes homogêneos (DEMSETZ, 1993; FOSS, 2005), ou seja, igualmente capazes de identificar oportunidades de negócio ou de instituir estruturas de governança eficientes. Consequentemente, o acesso 
ao mecanismo de preços se encontra aberto a todos os indivíduos, sendo a informação fornecida por esse sistema a base para suas atividades.

Inclusive, é fundamental salientar que a racionalidade limitada, para Williamson (1985), se resume à capacidade dos agentes de redigirem contratos completos. Nesse sentido, essa característica cognitiva não ameaçaria a destinação dos insumos aos seus melhores fins, tampouco a escolha de uma forma organizacional capaz de mitigar os problemas derivados da contratação complexa ${ }^{23}$. Assim, o humano descrito pela ECT conhece exatamente quais são as suas limitações e toma as atitudes necessárias para remediá-las.

Em outras palavras, o único obstáculo imposto ao aproveitamento de oportunidades de negócio seria a possibilidade de expropriação ex-post de investimentos idiossincráticos (KLEIN; CRAWFORD; ALCHIAN, 1978; WILLIAMSON, 1985). Por isso, a identificação de uma demanda específica entre os consumidores somente se transforma em uma ação efetiva quando garantias são concedidas aos interessados nessa empreitada. Daí a necessidade de instituição de uma forma organizacional adequada, capaz de garantir não apenas a maximização do valor derivado da cooperação como também o menor dispêndio de recursos possível.

Dessa forma, os problemas associados aos custos de transação são considerados, pela ECT, o resultado direto da comercialização de ativos específicos, e portanto, da instituição de estruturas de governança alternativas. Segundo a lógica apresentada por Williamson (1985, 1991), intercâmbios realizados no mercado não enfrentam os dilemas decorrentes da existência desses custos, de modo que a preocupação com a sua minimização é um resultado direto da instituição de outras formas organizacionais.

Mais especificamente, a perspectiva da governança considera um contexto no qual a preocupação com a economia de custos de transação por parte dos agentes tem início apenas a partir de uma iniciativa visando a organização consciente das transações. Não por acaso, os trabalhos dedicados ao tema da cooperação concentram as suas atenções no processo de manutenção e readequação dessas estruturas alternativas de governança. Com

\footnotetext{
${ }^{23}$ No caso, é interessante observar que estudos (LOADER, 1995) vem demonstrando que a percepção dos indivíduos acerca do grau de especificidade dos ativos envolvidos em uma relação pode variar. Dessa maneira, a própria escolha da forma organizacional mais adequada para a governança de um intercâmbio poderia ser afetada.
} 
isso, eventuais problemas enfrentados pelos indivíduos e que independam desse quadro de dependência bilateral são desconsiderados.

Nesse sentido, a ECT não chega a abordar a totalidade dos efeitos decorrentes do processo de descoberta dos preços relevantes. Embora Williamson (1991) demonstre que cada modo de adaptação específico está relacionado a um mecanismo de resolução de controversias próprio, a ECT considera que as partes sempre detém a melhor informação sobre uma transação. Dessa maneira, a atuação eficiente do judiciário estaria limitada à proteção dos intercâmbios típicos de mercado, em que a padronização é a regra.

Justamente por serem os maiores conhecedores das características de uma transação, parece natural que os indivíduos descritos pela ECT detenham toda a informação relativa aos preços ligados ao ativo comercializado. Está explicado, portanto, a razão dos estudos influenciados pela perspectiva da governança não considerarem a distribuição do valor derivado da cooperação um tema problemático após o estabelecimento de um arranjo organizacional (MENARD, 1996; WILLIAMSON, 1991).

De fato, sob essa lógica os indivíduos saberiam exatamente qual parcela da riqueza resultante da relação lhes caberia caso o compromisso fosse mantido. Indo além, somente se engajariam em uma relação baseada na comercialização de ativos específicos caso tivessem seus direitos reconhecidos. Dito de outra forma, o objetivo das partes ligadas a um arranjo organizacional alternativo é assegurar o cumprimento integral das promessas feitas no momento inicial da relação.

Exemplo típico disso é a atenção que a perspectiva da governança dá ao problema da seleção adversa. Em linhas gerais, tal fenômeno ocorre quando uma das partes em um intercâmbio possui uma informação indisponível ao outro agente, podendo utilizá-la de maneira oportunista ${ }^{24}$. Como principal consequência, a seleção adversa resulta na queda na qualidade média dos ativos oferecidos em um mercado com esse problema. Afinal, os vendedores não teriam como convencer os consumidores de que seu comportamento é

\footnotetext{
${ }^{24}$ O caso clássico, apresentado por Akerlof (1970), é o do vendedor de carros usados, cujo conhecimento do produto oferecido é bastante superior ao do comprador que deve decidir em apenas alguns minutos.
} 
honesto, justamente devido à impossibilidade de mensuração instantânea do desempenho do ativo.

Assim, a organização consciente das transações elimina o problema da seleção adversa, pois contribui para o cumprimento das promessas por parte dos agentes, sendo a disponibilização das informações relativas ao desempenho dos ativos uma prova disso. Da mesma maneira, contribui para a eficiência desse arranjo, já que a transparência resultante levaria a uma economia de recursos na resolução de conflitos de interesse entre as partes. Mais especificamente, a coordenação explícita assegura o aproveitamento dos benefícios advindos da cooperação, que nesse caso superariam os eventuais ganhos derivados de uma ação oportunista.

\subsection{O foco na minimização dos custos de governança}

Justificada sob a lógica da eficiência, a organização econômica tem assumido, nas últimas décadas, uma face crescentemente benigna. Desde as primeiras abordagens relacionando a existência da firma a pretensões monopolistas, passando pela visão coaseana e o desenvolvimento da ECT, é notável a guinada desse campo de estudo rumo a uma nova interpretação para o planejamento humano na esfera econômica. Nesse sentido, a preocupação com as distorções decorrentes da existência de assimetrias vem dando lugar, com distintos graus de ênfase, à exaltação dos benefícios da coordenação.

Isso não significa, porém, que considerações de outra ordem tenham sido irrelevantes para o desenvolvimento do neoinstitucionalismo econômico. Exemplo disso é a afirmação de Klein, Crawford e Alchian (1978) de que a existência de poder de mercado constituiria um fato incontornável das relações econômicas, principalmente em um cenário marcado pela presença de ativos específicos. Na maioria dos casos, inclusive, tal realidade não acarretaria qualquer ineficiência, influenciando unicamente a distribuição do valor resultante da cooperação.

Anos mais tarde, Williamson (1985) adota uma abordagem voltada exclusivamente ao papel da eficiência na organização econômica. Dessa maneira, as estruturas de governança 
descritas em seu “The Economic Institutions of Capitalism” visam unicamente minimizar os custos de participação nos mercados. Temas como a eventual presença de assimetrias no interior das organizações são pouco explorados, e quando o são, reforçam a percepção de que a busca por eficiência constitui a principal justificativa para as ações dos agentes.

O interessante é que o mundo descrito por Williamson para a construção de sua teoria está longe de ser uma terra de paz e harmonia. No cenário em que a ECT é ambientada, a adoção de estratégias oportunistas é uma possibilidade real, agravada pelo fato de que os agentes são incapazes de se proteger por meio de contratos completos. Dessa maneira, a atividade econômica estaria cercada de uma série de perigos, cuja gravidade exigiria dos indivíduos medidas apropriadas de salvaguarda.

Por outro lado, exacerbar a influência desses riscos sobre o comportamento dos agentes constituiria certamente um erro. De fato, o mundo da ECT demanda cuidados mais intensos que o cenário walrasiano, por exemplo. Entretanto, é notável a capacidade das estruturas de governança descritas por Williamson de mitigar os problemas ligados ao oportunismo, ou ainda de amenizar o efeito da racionalidade limitada sobre os resultados da relação. Assim, a instituição de arranjos organizacionais cumpriria de forma adequada o seu objetivo de evitar a trapaça, abrindo caminho para que as preocupações dos agentes se voltassem unicamente à busca por maior eficiência.

Exemplo dessa visão exageradamente benigna da organização econômica é dado por Arruñada (2002) em seu estudo das relações entre as cadeias varejistas e seus fornecedores. De acordo com esse autor, os supermercados exerceriam um papel próximo ao do judiciário na coordenação das relações com seus parceiros, com a vantagem de que a posse de informações mais precisas tornaria essa opção menos custosa. Com isso, a administração da cadeia por parte dessas redes garantiria não apenas maior eficiência adaptativa ao conjunto dos agentes envolvidos, como também a minimização dos custos relacionados à manutenção desse arranjo.

Talvez o aspecto mais controverso da análise de Arruñada seja sua opinião de que uma das partes na relação, seja devido à reputação ou à repetição de transações, assumiria com o tempo uma posição de imparcialidade. Dessa maneira, poderia assumir o papel de garantidor da estabilidade da relação, adotando medidas disciplinares contra aqueles que 
contrariassem as expectativas de desempenho. A busca por eficiência seria, assim, a única razão para a ação quase-judicial das redes varejistas. Inclusive, tal atribuição poderia ser concedida em casos em que a presença de ativos específicos não se verificasse, ou seja, as transações tivessem características semelhantes àquelas de mercado.

\subsection{Um olhar além dos arranjos organizacionais}

Apesar de constituir um caso de exagero no uso da lógica da eficiência, o trabalho de Arruñada (2002) ilustra bem a forma como os custos de transação tem sido considerados no estudo da organização econômica. Devido à influência da interpretação de Williamson (1985, 1996), é evidente a ênfase concedida à minimização dos gastos relativos ao estabelecimento e manutenção das estruturas de governança em detrimento de aspectos igualmente relevantes para a rotina dos indivíduos.

Obviamente, a aceitação crescente da abordagem proposta por Williamson se deve à sua capacidade de geração de hipóteses testáveis. Inclusive, tal característica constitui a principal vantagem da ECT quando comparada com outras teorias dedicadas ao estudo das formas organizacionais. No entanto, é inegável que o avanço possibilitado pela formalização da noção dos custos de transação nesses moldes decorre, em grande parte, de uma simplificação do raciocínio coaseano.

De fato, o resgate da contribuição deixada por "The Nature of the Firm" ao longo dos anos 70 se voltou, de maneira crescente, à segunda categoria de custos de transação identificada por Coase, qual seja: aquela relacionada ao processo de negociação e conclusão contratual (KLEIN; CRAWFORD; ALCHIAN, 1978; WILLIAMSON, 1985, 1996). Inspirado em uma situação particular, marcada pela presença de ativos específicos, esse enfoque acabou contribuindo para uma concentração exagerada das atenções na minimização dos custos decorrentes da organização econômica consciente.

Assim, equivaler uma noção tão ampla como a dos custos de transação à uma única interpretação constitui um grave erro. Embora possua uma série de potencialidades, a visão de Williamson falha ao não considerar as particularidades individuais dos agentes 
descritos, igualando as restrições enfrentadas por cada pessoa. Tal limitação é ainda mais grave quando se tem em conta a adoção, por parte da ECT, de um pressuposto comportamental como a racionalidade limitada ${ }^{25}$.

Um possível argumento de defesa da ECT seria o de que, tal qual estabelecida, essa visão se propõe a analisar um tópico bem definido, qual seja: a coexistência de formas organizacionais alternativas no mundo atual. De fato, as hipóteses derivadas da contribuição teórica de Williamson visam iluminar essa questão. Entretanto, a consideração exclusiva das características da transação em um cenário habitado por indivíduos homogêneos acaba levando a uma descrição empobrecida do mundo real.

Desde o início da década de 90, uma série de estudos (LANGLOIS, 1992; DEMSETZ, 1993; FOSS, 2005) tem questionado o tratamento dado pela ECT aos indivíduos e organizações. Questões como a razão para a heterogeneidade entre firmas dedicadas à mesma atividade, ou ainda os motivos relacionados à escolha de um parceiro específico para a transação, são abordadas por esses trabalhos, garantindo a ampliação do campo de visão dos pesquisadores dedicados à organização econômica. Tais esforços, porém, partem de uma perspectiva distinta daquela adotada pela ECT, de modo que sua plena aceitação dependeria de uma integração teórica mais ampla ${ }^{26}$.

Isso não significa que faltem ao neoinstitucionalismo econômico elementos capazes de permitir um olhar mais realista sobre os indivíduos. Ora, a própria noção de custos de transação fornece inúmeras potencialidades à espera de um olhar mais atento. Veja-se, por exemplo, a afirmação feita por Coase (1937), de que a descoberta dos preços relevantes não é gratuita. Nesse sentido, é interessante notar como, ao longo das sucessivas propostas de refinamento do raciocínio coaseano, tal item foi tão pouco aproveitado.

$\mathrm{Na}$ verdade, o esquecimento parcial desse argumento se deve à influência da lógica marginalista sobre o neoinstitucionalismo econômico. Afinal, as teorias da firma mais

\footnotetext{
${ }^{25}$ Ainda que o próprio Williamson (1985) reconheça que o tipo de racionalidade limitada usada em sua abordagem constitui uma forma mais branda do que aquela descrita por outros trabalhos. De fato, autores como Selten (1990) defendem a ideia de que a racionalidade limitada está dissociada, por exemplo, do comportamento maximizador, algo que demonstra a separação entre a versão desse pressuposto adotada pela ECT e aquela considerada por uma série de estudiosos do tema.
}

${ }^{26}$ Algo que, inclusive, já vem sendo buscado por autores como Foss e Foss (2005) e Saes (2008). 
utilizadas no início do século XXI convivem lado a lado com a pressuposição de que o mecanismo de preços constitui a forma mais adequada para a organização da vida econômica. Por isso, sua destituição do papel de indutor da ordem somente seria possível caso um bom motivo fosse encontrado.

Entretanto, no mundo real há limitações que incidem diretamente sobre os indivíduos, independente da estrutura de governança em que estejam inseridos. Em especial, os custos de descoberta das informações relevantes devem ser incluídos nas análises voltadas à organização consciente. Não raramente, os agentes se relacionam com o mecanismo de preços de forma indireta, de modo que as recompensas recebidas por seu esforço refletem o julgamento de seus parceiros. Considerar que tal aspecto da rotina econômica se encontra livre de estratégias oportunistas constitui um erro.

\subsection{Considerações finais}

Este trabalho apresentou uma discussão acerca da noção de "custos de transação" utilizada pela ECT, e as implicações dessa escolha para a observação de determinados fenômenos. Em especial, foi mostrado que a obtenção das informações necessárias a fim de delimitar a quase-renda não é automática, dependendo do gasto individual de recursos. Naqueles casos em que os custos de tal atividade são proibitivos a um dos indivíduos na relação, não há nenhuma garantia de que a outra parte irá fornecer essa informação.

Em grande parte, a desconsideração desse fato se deve à concepção abstrata dos mercados utilizada pela ECT. Nesse sentido, a abordagem de Williamson considera que todas as informações relevantes serão obtidas pelos agentes em algum momento. Desse modo, o problema da organização econômica se limitaria ao cumprimento de promessas a fim de garantir a cooperação no longo prazo. No entanto, em muitos casos os dados necessários para a determinação da quase-renda decorrente da especialização produtiva se encontram indisponíveis aos indivíduos, permitindo que a captura de parte desse valor possa ser feita mesmo em um contexto de manutenção da relação. 
O reconhecimento de tal realidade, se por um lado aprofunda os consequências do oportunismo para as ações econômicas, por outro abre espaço para uma compreensão mais ampla das motivações dos agentes. Afinal, a heterogeneidade nos padrões de distribuição dos ganhos derivados da cooperação econômica pode estar relacionada, entre outros fatores, à transferência de informações entre as partes. Não raramente, dados indisponíveis a determinado agente são fornecidos por seus parceiros, em uma possível mostra da existência de interesses que vão além do cálculo maximizador enfatizado pela ECT. 


\section{A ECONOMIA DOS CUSTOS DE TRANSAÇÃO E O ENRAIZAMENTO SOCIAL: UMA PROPOSTA DE INTEGRAÇÃO TEÓRICA}

\subsection{O problema}

Impulsionada a partir do trabalho de Williamson $(1985,1996)$, a Economia dos Custos de Transação (ECT) vem obtendo considerável sucesso na geração de estudos empíricos. A partir da preocupação com a geração de hipóteses testáveis, tal abordagem viabilizou o aumento no interesse pelo estudo da organização econômica, garantindo a retomada do legado de Ronald Coase. Conforme uma série de trabalhos demonstra (SHELANSKI; KLEIN, 1995; RICHMAN; MACHER, 2006), é crescente a produção de textos dedicados a contribuir com essa agenda de pesquisa.

No entanto, o privilégio concedido a determinadas variáveis em detrimento de outras tem levado à emergência de críticas à ECT. Entre os sociólogos, a principal objeção ao trabalho de Williamson é a de que sua estrutura analítica não considera de forma adequada o papel das relações sociais no cotidiano econômico ${ }^{27}$. Afinal, conforme enfatiza Granovetter (2005), a capacidade preditiva de teorias dedicadas ao cotidiano econômico é enfraquecida quando as motivações dos indivíduos não são devidamente consideradas.

Embora tenha buscado responder a essas objeções, é frágil a tese de Williamson (1991, 1993b) de que os efeitos de tais variáveis sobre as transações seriam apreendidos pela existência de custos de governança distintos em cada sociedade. Mais especificamente, limitar a consideração acerca do enraizamento (embeddedness) ao papel deste fator na magnitude dos custos de governança resulta em um tratamento incompleto do tema. Por outro lado, a própria multiplicidade de definições compatíveis com a noção de enraizamento dificulta sua integração à ECT.

De fato, Smelser e Swedberg (1994) argumentam que é necessária a separação adequada das diversas dimensões em que o enraizamento se manifesta, a fim de garantir uma maior

\footnotetext{
${ }^{27}$ Indo além, pode-se dizer que tal crítica se estende ao núcleo duro das ciências econômicas, haja vista o fato de que a teoria neoclássica adota uma perspectiva ainda mais restrita nesse tópico.
} 
especificação teórica. Independente do seu atual grau de precisão, porém, tal noção constitui um tópico fundamental para a compreensão dos fenômenos sociais. Consequentemente, uma importante tarefa corresponde à integração dessas variáveis ao estudo da organização econômica. Em outras palavras, de que maneira os efeitos derivados da existência do enraizamento poderiam ser apreendidos pela Economia dos Custos de Transação?

Viabilizar tal objetivo, entretanto, depende do reconhecimento das principais virtudes da contribuição teórica de Williamson. Apesar das críticas, a capacidade da ECT de produzir inúmeros trabalhos empíricos desde meados da década de 80 demonstra a robustez de sua estrutura analítica. Assim, suas eventuais limitações dizem respeito ao grau de detalhamento da previsão fornecida, ou ainda, à sua capacidade de responder determinadas questões. Portanto, torna-se vital a delimitação dos problemas ao alcance da ECT, de modo a especificar seus limites teóricos.

Da mesma forma, é importante uma avaliação acerca do papel do mecanismo de preços para o direcionamento da atividade econômica. Desde o começo dos anos 90, uma série de trabalhos tem demonstrado a insuficiência do tratamento abstrato dado pela teoria neoclássica aos mercados (BLOCK, 1990; ABRAMOVAY, 2004). Por outro lado, o reconhecimento da existência desses problemas não anula as diversas potencialidades associadas à análise marginalista, principalmente em relação à sua capacidade de debater temas como a formação de preços e a alocação de recursos.

Tendo esse complexo quadro em vista, o trabalho em tela busca integrar um aspecto específico do enraizamento ao arcabouço teórico proporcionado pela ECT, qual seja: a transferência de informações acerca dos preços relevantes a agentes incapazes de obtê-las. Para tanto, discute a concepção de mercado considerada por Williamson, questionando a suficiência da ideia de custo de transação utilizada em sua teoria. Fundamental para esse artigo será a contribuição dada por Block (1990) para o estudo dos mercados. 
A Economia dos Custos de Transação (ECT) se caracteriza pela adoção de uma perspectiva microanalítica. Mais especificamente, a unidade de análise escolhida por Williamson $(1985,1996)$ é a transação econômica, cuja realização se dá em um mercado com características semelhantes àquele considerado pela teoria neoclássica. Estender tal abordagem a outros segmentos da ação humana, portanto, implica a delimitação exata do que seria transacionado nessa nova situação. Além disso, a descrição do ambiente em que tais intercâmbios são realizados exige uma aproximação em relação à forma como um mercado é ilustrado por essa vertente.

Em outras palavras, a ECT adota o individualismo metodológico como ponto de partida para a compreensão da natureza humana. Da mesma forma, Williamson $(1985,1996)$ não se opõe à concepção de mercado utilizada pela maioria dos economistas. Pelo contrário, tal arranjo é visto como a forma mais eficiente de realizar um grande número de transações, possuindo a vantagem adicional de oferecer incentivos poderosos aos agentes (WILLIAMSON, 1991). A única limitação relacionada ao uso do mercado estaria na ausência de garantias em casos nos quais a realização de investimentos idiossincráticos fosse requerida.

Porém, tais situações não decorreriam de uma deficiência inerente ao funcionamento do sistema de preços. Ora, seria um erro exigir deste mecanismo algo mais que o fornecimento dos preços. Assim, a emergência de estruturas de governança alternativas decorre da falta de opções para a comercialização de ativos específicos pelo seu valor integral. Nos mercados descritos por Williamson $(1985,1996)$, não é tanto a existência de garantias legais, e sim a multiplicidade de opções para a comercialização de bens a principal garantia dos indivíduos em caso de quebra de compromisso.

Afinal, a principal preocupação da linhagem teórica a qual a ECT se filia é justamente assegurar o recebimento da quase-renda derivada da realização de investimentos idiossincráticos (KLEIN; CRAWFORD; ALCHIAN, 1978; WILLIAMSON, 1985). Nesse sentido, a inexistência de ativos específicos torna tal problema insignificante em diversos mercados. É somente a partir da realização de investimentos dotados de alguma 
idiossincrasia que emergiriam riscos aos agentes, sendo a resposta a este desafio dada por meio da construção de arranjos organizacionais alternativos ${ }^{28}$.

Não por acaso, a hipótese básica da ECT é a de que há um alinhamento entre as características da transação econômica observada e as estruturas de governança empregadas pelos agentes (WILLIAMSON, 1985). Conforme a figura 2 demonstra, uma maior especificidade dos ativos levará necessariamente a um aumento dos custos de governança associados a um intercâmbio. No entanto, Williamson $(1985,1996)$ argumenta que os arranjos organizacionais instituídos a fim de garantir tais atividades, apesar de acarretarem gastos maiores, serão delineados com base na lógica da eficiência. Consequentemente, somente serão estabelecidos caso os benefícios derivados dessa ação superem os custos de governança adicionais.

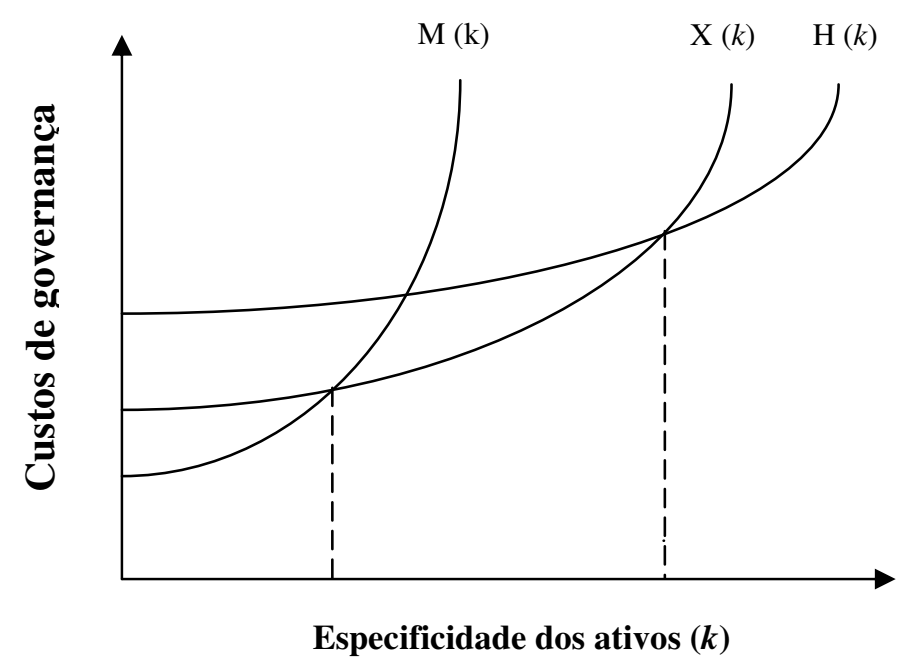

Figura 2: Especificidade dos ativos e os custos de governança FONTE: Baseado em Williamson (1991)

Entretanto, o reconhecimento de que intercâmbios podem diferir uns dos outros não constitui uma condição suficiente para a constituição de arranjos organizacionais alternativos. De fato, bastaria que os indivíduos respeitassem os direitos alheios sobre

\footnotetext{
${ }^{28}$ Williamson (1985) argumenta que outros fatores poderiam contribuir para a instituição de arranjos organizacionais alternativos, como a frequência e a incerteza. No entanto, a grande maioria dos estudos empíricos baseados na ECT concede um papel central à especificidade dos ativos para a geração de hipóteses. Ver: Zylbersztajn (2005a).
} 
investimentos específicos para que o mercado fosse utilizado em todas as transações ${ }^{29}$. Inclusive, tal realidade viabilizaria uma economia considerável de recursos. Por isso, o que traz a necessidade de tais estruturas, segundo a ECT, é a adoção de pressupostos comportamentais diferenciados, entre os quais o oportunismo.

De acordo com a definição de Williamson (1985, 1993b), a afirmação de que os agentes econômicos são oportunistas equivale a dizer que estes empreendem a busca do autointeresse com astúcia, podendo ocultar informações relevantes para uma transação ou ainda quebrar compromissos, por exemplo. Longe de generalizar tal comportamento, porém, a ECT se baseia na crença de que ações oportunistas na esfera econômica podem ocorrer a qualquer momento. Dessa maneira, a mera probabilidade de que tais atos sejam praticados torna a construção de salvaguardas um imperativo às partes.

A centralidade dada ao oportunismo como pressuposto comportamental rendeu a Williamson uma série de críticas. Em especial, tal opção originou uma rápida resposta por parte da sociologia (GRANOVETTER, 1985), baseada na defesa de uma visão diferenciada acerca da organização econômica. Para este grupo de autores, a ECT desconsidera o papel das relações sociais para a realização de transações, limitando-se a observar as características dos ativos transacionados. Consequentemente, tal abordagem seria incapaz de apreender o significado do enraizamento na rotina econômica dos indivíduos.

Respondendo a essas objeções, Williamson (1991, 1993b) argumenta que aspectos referentes ao enraizamento são apreendidos pela ECT por meio da consideração do ambiente institucional em que se dão os intercâmbios analisados. Isso seria possível graças ao caráter comparativo da análise organizacional proposta por Williamson. Indivíduos baseados em sociedades coesas tenderiam a evitar litígios, preferindo a negociação bilateral. Nesse sentido, o enraizamento reduziria os custos de governança das transações, tornando a manutenção dos diversos arranjos organizacionais uma tarefa menos onerosa às partes.

\footnotetext{
${ }^{29}$ Ademais, o mecanismo de preços organizaria de maneira eficiente esses intercâmbios caso os agentes fossem capazes de redigir contratos completos, algo que Williamson (1985) considera impossível devido ao fato destes serem dotados de racionalidade limitada.
} 
Indo além, Williamson (1993a, 1993b) considera desnecessário o debate acerca da existência de confiança para a análise da organização econômica. Apesar de concordar que exageros na adoção de uma abordagem comportamental calculativa são contraproducentes, o autor argumenta que uma discussão em torno da confiança confundiria mais que o devido. Na opinião de Williamson (1993a), noções como a de risco seriam preferíveis nesse campo, de modo que o uso do termo confiança se reservaria a relações em que inexistisse motivação econômica.

\subsection{O enraizamento e as motivações dos agentes}

Conforme mostrado na seção anterior, a ECT se caracteriza por uma perspectiva microanalítica, buscando gerar hipóteses testáveis para o estudo da organização econômica. A fim de empreender tal objetivo, Williamson $(1985,1996)$ se baseia em pressupostos comportamentais específicos, entre os quais o oportunismo, além de enumerar fatores que afetariam a capacidade do mecanismo de preços de coordenar as transações. Entre as variáveis apresentadas, a especificidade dos ativos é a que tem recebido maior atenção por parte da literatura (ZYLBERSZTAJN, 2005a), sendo a base para uma série de estudos empíricos.

Apesar de seu considerável sucesso na geração de hipóteses para o estudo da organização econômica, a ECT não se encontra livre de críticas. Sociólogos como Granovetter (1985) argumentam que a contribuição de Williamson é incapaz de apreender aspectos relacionados às relações sociais presentes nas transações consideradas. Dessa maneira, tal perspectiva subestimaria o papel da confiança para a governança dos intercâmbios, algo que decorreria da desconsideração do enraizamento no arcabouço teórico da ECT. Já para Williamson (1993b), esses aspectos estariam contidos nas características do ambiente institucional em torno das transações.

No entanto, embora busque demonstrar a possibilidade de acomodação entre a ECT e a noção do enraizamento, Williamson segue concedendo protagonismo incontestável à transação. Com isso, o reconhecimento de que tais intercâmbios são realizados em ambientes institucionais diversos não chega a modificar as conclusões derivadas de sua 
teoria. Afinal, inexistem garantias de que sociedades caracterizadas por um nivel maior de enraizamento não possuam indivíduos com propensão à adoção de um comportamento oportunista. Portanto, a necessidade de estabelecimento de salvaguardas contratuais, sob o olhar da ECT, é semelhante qualquer que seja o grupo social analisado.

$\mathrm{Na}$ prática, a consideração do ambiente institucional no arcabouço teórico proporcionado pela ECT influenciaria unicamente os custos relativos de governança. Dito de outra forma, agentes baseados em sociedades caracterizadas por um grau maior de enraizamento tenderiam a gastar menos recursos na organização de suas transações econômicas. Porém, a concessão de garantias às partes seria indispensável para a realização desses intercâmbios (WILLIAMSON, 1983), ainda que o conflito constituisse uma possibilidade remota.

Da mesma forma, os efeitos decorrentes de diferenças no aparato legal disponível em cada sociedade tampouco são captados em sua totalidade pela ECT. Ora, o grau de especificidade dos investimentos não está ligado à capacidade do judiciário de resolver conflitos, e sim à quantidade de fornecedores e compradores potenciais do ativo em questão. Para a ECT, um bem se torna idiossincrático à medida que sua produção gera uma quase-renda passível de apropriação por parte dos agentes envolvidos no intercâmbio (KLEIN; CRAWFORD; ALCHIAN, 1978). Assim, a adoção de um determinado arranjo organizacional responde unicamente às características do ativo transacionado.

De fato, o próprio Williamson (2000) argumenta que sua preocupação reside em um nivel analítico inferior àquele necessário para a plena apreensão do enraizamento ${ }^{30}$. Porém, sua insistência em associar tal noção ao trabalho de North (1993) distorce o significado da contribuição dos sociólogos nesse debate ${ }^{31}$. Ao equivaler tal variável ao ambiente institucional no momento da transação, a ECT não leva em conta aspectos ligados à construção da confiança entre as partes. Ademais, a inserção definitiva do enraizamento na

\footnotetext{
${ }^{30}$ De acordo com Williamson (2000), a ECT concentra suas atenções em um horizonte temporal de cerca de 10 anos, ao passo que o estudo de aspectos relativos ao enraizamento exigiria a análise de períodos de até mil anos. Inclusive, nesse trabalho o autor desmembra as dimensões compreendidas pelas instituições informais e formais, defendendo a ideia de que as últimas demorariam menos tempo para serem modificadas. Porém, tal diferenciação é irrelevante para a produção de conclusões derivadas da ECT, dado que ambas as dimensões estão representadas na curva de custos de governança (ver figura 2).

${ }^{31}$ Inclusive, a contribuição de North (1993) oferece um tratamento mais completo para o debate acerca do ambiente institucional do que aquele considerado por Williamson.
} 
análise organizacional acarreta o reconhecimento de que os humanos possuem motivações que vão além da esfera econômica, algo que Williamson não faz.

Um bom exemplo da dificuldade de integração entre a ECT e a noção de enraizamento é o trabalho de Klein (2002). Nele, é apresentada uma definição para o capital reputacional ligada exclusivamente aos lucros futuros derivados do relacionamento. De acordo com esse autor, sempre que a possibilidade de ganho no longo prazo existir, os agentes preferirão garantir os acordos sem recorrer à uma solução de terceira parte. Nesse sentido, a acomodação dos interesses das partes responderia ao retorno econômico que tal ação proporcionasse.

Em grande medida, a conclusão de Klein (2002) é semelhante àquela apresentada por Williamson (1993a) ao defender o cálculo racional para o estudo dos fenômenos econômicos. Afinal, se a expectativa de lucros futuros constitui a única motivação dos agentes em suas ações econômicas, logo a perenidade de um relacionamento depende apenas de uma avaliação dos benefícios pecuniários derivados de sua manutenção. Por outro lado, tal conclusão difere daquela apresentada por Granovetter (1985, 2005), para quem a análise do cotidiano econômico deve levar em conta fatores que transbordam as motivações consideradas pela ECT.

Mais especificamente, Granovetter (1985) alerta para a importância dos laços sociais na organização econômica, contrariando o argumento básico da Nova Economia Institucional $^{32}$, qual seja: o de que instituições são a melhor resposta à possibilidade de trapaça no intercâmbio entre agentes. Seu argumento, baseado na noção do enraizamento, reforça o papel das relações pessoais concretas e a estrutura das mesmas na geração de confiança e no desencorajamento do oportunismo. Dessa maneira, Granovetter defende a tese de que a lógica por trás das transações econômicas vai além da moralidade generalizada ou da garantia institucional.

A força da confiança, segundo Granovetter, não pertence às transações, mas às relações concretas por si só. Assim, o autor critica a hipótese de alinhamento proposta por

\footnotetext{
${ }^{32}$ A denominação Nova Economia Institucional agrupa o trabalho de autores como Ronald Coase, Douglass North, Oliver Williamson e Yoram Barzel, entre outros. É importante observar que há diferenças consideráveis nos trabalhos desses autores, sendo o interesse pelas instituições seu principal denominador comum.
} 
Williamson (1985), argumentando que a ECT superestima o poder das instituições de garantir o respeito dos agentes às normas. De acordo com Granovetter (1985), essas estruturas são incapazes de produzir confiança, de modo que é possível que existam firmas em que a cooperação interna seja mínima. Inversamente, o autor argumenta que relações sociais densas podem ser suficientes para garantir a governança de transações complexas por meio do mercado, o que contraria a essência da ECT.

Porém, Granovetter (1985) reconhece que essa posição não se encontra livre de críticas, propondo duas limitações importantes para seu enfoque: primeiramente, ações oportunistas seguirão existindo em um mundo onde as redes de relacionamento não são generalizadas; além disso, percalços poderão ocorrer mesmo que haja um histórico de convivência entre os agentes. Inclusive, esse autor reconhece que relações concretas podem dar origem a alianças cujo objetivo, explícito ou não, seja o de prejudicar concorrentes no cotidiano econômico.

\subsection{Ambiente institucional e enraizamento social}

Apesar das tentativas de demonstrar a compatibilidade natural entre a ECT e a noção de enraizamento, Williamson (1991, 1993b) limita de forma excessiva o real significado dessa expressão para os eventos econômicos. Em parte, isso se deve à presença de pressupostos comportamentais rígidos em sua abordagem. Ao vincular o enraizamento ao ambiente institucional, Williamson evita modificações no núcleo duro da ECT, entre as quais um abrandamento do oportunismo. Dessa maneira, os efeitos práticos de tal empreitada se mostram reduzidos, principalmente quando se tem em conta os argumentos dos sociólogos sobre o tema.

Por outro lado, o reconhecimento de Granovetter (1985) de que o enraizamento não elimina a ocorrência de ações oportunistas parece reforçar a hipótese básica da teoria de Williamson. Aos olhos de um acadêmico vinculado à ECT, tais limitações confirmariam a necessidade da instituição de salvaguardas contratuais. A afirmação de uma relação de confiança entre os agentes, embora capaz de diminuir os gastos ligados à organização dessas atividades, seria incapaz de substituir as garantias formais. Nesse sentido, o 
estabelecimento de estruturas de governança alternativas seguiria respondendo à idiossincrasia dos investimentos envolvidos na transação.

$\mathrm{Na}$ verdade, o embate em torno das diversas posições acerca da hipótese do alinhamento fornece uma representação incompleta da crítica sociológica à ECT. De fato, a incapacidade de Williamson (1991, 1993b) de justificar a presença do enraizamento em sua abordagem não se deve somente à manutenção do oportunismo como pressuposto comportamental. Afinal, o próprio Granovetter (1985) reconhece que a trapaça é parte da rotina social. Mais importante é o caráter generalizador que Williamson (2002) concede ao enraizamento, equivalendo tal noção a algo pertencente de forma homogênea a um grupo humano.

Assim, Williamson estende ao enraizamento a concepção supersocializada a qual já havia usado para descrever a firma anteriormente. Conforme aponta Granovetter (1985), uma das principais deficiências da ECT está na capacidade que esta concede aos arranjos organizacionais de mitigarem os problemas relacionados à governança econômica. Da mesma maneira, equivaler o enraizamento ao conjunto de regras informais de uma sociedade (WILLIAMSON, 2002) acarreta a crença de que os indivíduos obedecerão um conjunto de valores compartilhados simplesmente porque estes se consolidaram ao longo do tempo.

Portanto, o que as seções anteriores demonstram é que as tentativas de Williamson de integrar a noção de enraizamento à ECT apresentam dois problemas: em primeiro lugar, a associação entre o ambiente institucional e o enraizamento considera apenas os efeitos dessa variável sobre os custos de governança relativos em uma sociedade. Indo além, a própria concepção de enraizamento considerada por Williamson é imprecisa. Afinal, esta tanto superestima o papel das regras informais de influenciar o comportamento dos indivíduos quanto limita a atenção às motivações econômicas dos agentes nos intercâmbios.

Pelo contrário, a noção de enraizamento está ligada ao reconhecimento de que as ações na esfera econômica estão ligadas a fatores desvinculados da lógica maximizadora em seu conteúdo, objetivo ou processos (GRANOVETTER, 2005). Igualmente, ainda que instituições informais possam contribuir para a superação da possibilidade de trapaça em 
uma transação, estas são insuficientes para fazê-lo de forma integral. Evidentemente, o aprofundamento da confiança decorre do estabelecimento de uma relação entre os agentes, não precedendo tal ato.

Isso posto, a impressão inicial é a de que a integração entre a ECT e considerações de ordem sociológica seria incompatível. Entretanto, a própria multiplicidade de fatores vinculados às origens do enraizamento contribui para que tal conclusão seja precipitada. Fatores cognitivos, culturais e políticos, entre outros, se encontram inseridos no debate sobre o tema (SMELSER; SWEDBERG, 1994). Desse modo, qualquer trabalho dedicado ao enraizamento seria incapaz de reivindicar, na atualidade, o privilégio de englobar todos os seus aspectos. Integrar tal noção à estrutura da ECT implica, então, a delimitação de um foco claro.

Em linhas gerais, o que as pesquisas com inspiração sociológica vem demonstrando é que as estruturas sociais possuem um papel fundamental para a determinação dos resultados econômicos (BLOCK, 1990; UZZI, 1996; GRANOVETTER, 2005). Já a ECT explora problema semelhante, ainda que por meio da ênfase em outras variáveis. Por isso, a absorção de aspectos ligados ao enraizamento por parte da ECT depende da identificação de brechas em sua estrutura teórica que exijam uma explicação que vá além da lógica maximizadora.

Tendo em vista a adoção da transação como unidade analítica da ECT, tal busca deve estar ancorada em aspectos ligados ao relacionamento entre as partes. Nesse sentido, um possível ponto de partida para tal análise é a consideração acerca do ambiente em que tais intercâmbios são realizados. Conforme enfatizando anteriormente, a ECT se assenta em uma representação dos mercados semelhante àquela utilizada pela teoria neoclássica. Essa escolha, se por um lado possibilitou a considerável integração entre ambas as vertentes (RIORDAN; WILLIAMSON, 1985), por outro transporta algumas das limitações inerentes ao enfoque marginalista.

Assim, pode-se dizer que a ECT mantém o caráter abstrato dos mercados neoclássicos. Basicamente, Williamson (1985) acrescenta a pressuposição de que ativos podem ser dotados de um grau de especificidade não trivial, derivando daí sua principal hipótese, qual seja: a presença de investimentos idiossincráticos em uma transação levará à 
construção de arranjos organizacionais alternativos ${ }^{33}$. É sempre bom lembrar, a insuficiência do mecanismo de preços na governança desses intercâmbios deriva da falta de alternativas para a comercialização de ativos específicos em caso de quebra de compromisso.

No entanto, tal qual concebidos, os mercados descritos pela economia neoclássica são alvos de uma série de críticas. De acordo com Hayek (1996), a contribuição walrasiana descreve esses arranjos como sistemas em que todos sabem tudo. Com isso, a organização dos mercados seria automática sob tal perspectiva, algo que desconsidera o problema fundamental da dispersão do conhecimento em tais sistemas ${ }^{34}$. Afinal, a informação relevante para o funcionamento dos mercados se encontra dispersa em pequenas porções entre os indivíduos (HAYEK, 1945, 1996).

Quando transportado à realidade de um mercado composto por ativos idiossincráticos, o fato de que a informação relevante se encontra espalhada entre os agentes traz importantes implicações. À medida que passa a se basear em investimentos específicos, uma relação tende a limitar o número de indivíduos diretamente interessados no ativo transacionado. Destarte, as pessoas cujo conhecimento afeta o preço desse bem possivelmente estarão mais dispersas, afetando a propagação de tais informações. Consequentemente, a obtenção de dados será mais difícil em mercados com essas características.

\subsection{A obtenção de informações nos mercados}

Mercados são construções sociais, dependentes da ação humana para funcionar ${ }^{35}$. Mesmo os exemplos que mais se aproximam do ideal descrito pela teoria neoclássica, como as

\footnotetext{
${ }^{33}$ A adoção de pressupostos comportamentais diferenciados por parte da ECT, apesar de representar uma diferença em relação ao paradigma neoclássico, não está ligada à ideia de mercado. Afinal, a racionalidade limitada e o oportunismo pertencem aos indivíduos que participam desses arranjos.

${ }^{34}$ São diversos os desdobramentos da crítica de Hayek à representação neoclássica dos mercados, algo que foge aos objetivos do presente estudo. Nesse sentido, as observações do economista austríaco são aqui utilizadas como uma forma de atentar para o caráter abstrato dos mercados considerados pela ECT.

35 Há uma literatura crescente buscando demonstrar a importância da interação humana para o estabelecimento dos mercados (FLIGSTEIN, 1996; ABRAMOVAY, 2004). Debater tal processo, porém, não constitui o objetivo desse artigo.
} 
bolsas de valores, se baseiam em uma complexa estrutura burocrática. Por isso, subestimar sua importância para o fornecimento das informações relevantes aos agentes constitui uma falha grave. Se por um lado a Nova Economia Institucional reconhece que a existência das instituições acarreta custos aos agentes (COASE, 1960), por outro é evidente a influência que a concepção abstrata dos mercados possui sobre seu desenvolvimento.

Dessa maneira, a ECT não chega a discutir a forma como a informação relevante para a atuação no sistema econômico chega aos indivíduos. Em grande medida, tal limitação decorre da influência da abordagem walrasiana sobre essa vertente. Apesar de adotar uma série de pressupostos diferentes daqueles usados pela microeconomia neoclássica, Williamson não questiona os fundamentos dessa teoria. Nesse sentido, sua constante referência a Hayek se resume à exaltação feita pelo economista austríaco acerca da impressionante capacidade do mecanismo de preços de garantir a organização econômica.

Consequentemente, as estruturas de governança instituídas pelos agentes se destinariam a garantir o maior alinhamento possível entre a produtividade dos fatores e as recompensas recebidas. Nesse sentido, tal tarefa seria executada tanto por meio da mensuração da contribuição individual para o produto final (ALCHIAN; DEMSETZ, 1972) quanto pela proteção da quase-renda derivada da especialização produtiva (KLEIN; CRAWFORD; ALCHIAN, 1978; WILLIAMSON, 1985). Entretanto, todos saberiam de antemão o valor dos insuímos possuídos, e o quanto ganhariam caso cooperassem com outras pessoas.

No mundo real, porém, a dispersão dos dados relevantes aos agentes não é automática. Redes sociais, por exemplo, afetam diretamente o fluxo de informações (GRANOVETTER, 1973, 2005). Da mesma forma, as instituições possuem um papel central na disponibilização desses dados. Inclusive, tais estruturas influenciam diretamente os custos individuais de obtenção da informação. De fato, uma das principais vantagens associadas à mercados em que muitas pessoas participam diz respeito à divisão do gasto total para a manutenção de seu funcionamento.

Já segundo a ECT, os custos de transação corresponderiam aos gastos incorridos para a manutenção de estruturas de governança. Não por acaso, Williamson evoca a definição de Arrow (1969) para o termo, relacionando tal noção aos custos de funcionamento do 
sistema econômico ${ }^{36}$. Assim, os custos de transação resultariam unicamente da interação entre os agentes, estando sua existência desvinculada de características individuais. Em um planeta onde todos são oportunistas e dotados de racionalidade limitada, minimizar tais custos acarretaria escolher a forma mais eficiente de garantir a realização das transações.

No entanto, os custos de transação também afetam a obtenção das informações relevantes por parte dos agentes. À medida que investimentos específicos são feitos, os mercados commodity perdem a capacidade de fornecer os preços às partes, de modo que os custos individuais para a obtenção desses dados aumentam consideravelmente. Dessa maneira, é possível que muitos agentes sejam incapazes de conseguir tal informação a partir de certo nivel de idiossincrasia dos ativos. Entre as consequências dessa realidade, o alinhamento entre a participação dos insumos nos resultados econômicos e sua recompensa poderia ser afetado.

Com isso, o oportunismo não se resumiria à quebra de compromisso em uma situação de dependência bilateral, ou ainda à diminuição do esforço produtivo (shirking) devido à dificuldade de mensurar a contribuição individual. Indo além, agentes capazes de obter a informação relevante acerca dos preços dos ativos transacionados podem utilizar tal capacidade para a apropriação da quase-renda decorrente da especialização produtiva. Nesse sentido, a estabilidade de um relacionamento econômico pode encobrir eventos que as ferramentas analíticas existentes na atualidade são incapazes de especificar.

\section{6 contribuição de Block para o estudo dos mercados}

Tendo em vista o conteúdo discutido até o momento, a contribuição de Block (1990) para o estudo dos mercados apresenta elementos capazes de auxiliar na integração do enraizamento ao arcabouço da ECT. Sua proposta de análise de tais estruturas, assentada em dois contínuos, se presta a avaliar o papel dos preços e da racionalidade instrumental no cotidiano econômico, temas presentes tanto na agenda de pesquisa da Nova Economia Institucional quanto da sociologia econômica.

\footnotetext{
${ }^{36}$ Arrow (1969, p. 60) afirma que “... transaction costs are the costs of running the economic system”.
} 
O primeiro contínuo exposto por Block (1990) ilustra o papel dos preços para a realização de intercâmbios econômicos. Segundo o autor, a teoria neoclássica falha ao não considerar de forma adequada os diversos arranjos organizacionais observados nas sociedades contemporâneas. Nesse sentido, Block argumenta que a visão de que o mecanismo de preços garantiria o equilíbrio é insuficiente. Pelo contrário, diversas estruturas de governança, resultantes da interação social entre os humanos, são fundamentais para explicar o cotidiano econômico.

Dessa maneira, Block apresenta um contínuo dedicado a representar os distintos graus de marketness na economia. Mais especificamente, o autor reserva um dos extremos de seu esquema àquelas transações em que o preço constitui o único mecanismo organizacional existente. Tais intercâmbios correspondem à abstração descrita pela teoria neoclássica, sendo a capacidade de autorregulação e adaptação à choques exógenos as principais características dos mercados em que essas interações são a regra.

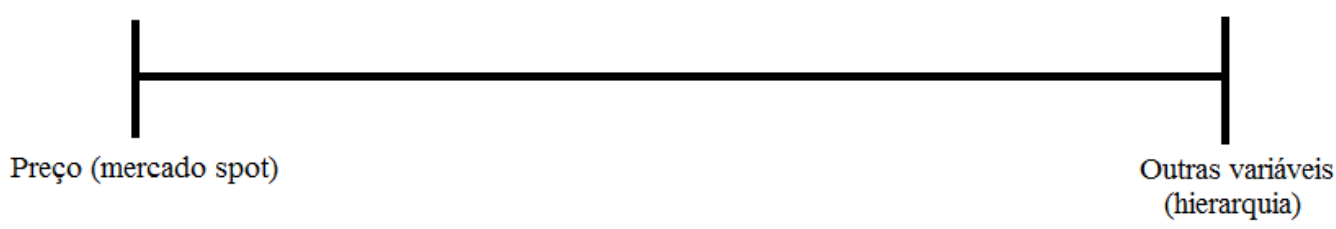

Figura 3: Block e o grau de marketness nas transações econômicas FONTE: Baseado em Block (1990)

Por outro lado, à medida que novos elementos ganham importância para a realização de uma transação, sua localização no contínuo apresentado acima se deslocará em direção à outra ponta. Com isso, Block busca chamar a atenção para a insuficiência dos sinais fornecidos pelo mecanismo de preços para a organização de uma série de intercâmbios. Nesses casos, seriam estruturas delineadas a partir da ação consciente dos humanos as responsáveis pela coordenação no sistema econômico.

De acordo com Block (1990), o contrato é o melhor exemplo de distanciamento entre o mundo real e o modelo de equilíbrio geral. Sua existência seria justificada pela necessidade de proteger as partes de eventuais problemas derivados da assimetria 
informacional em um intercâmbio. Em outras palavras, o estabelecimento de acordos formais responderia à demanda por salvaguardas capazes de mitigar a trapaça em uma transação. Igualmente, a proliferação dos contratos nas sociedades capitalistas constituiria uma demonstração da importância das relações de longo prazo para o funcionamento do sistema econômico.

Afinal, conforme salienta Block (1990), quanto mais longo o contrato, menor o grau de marketness em uma transação. Embora seja possível estabelecer cláusulas destinadas a garantir certa flexibilidade a tais acordos, é evidente que relações de longo prazo são menos sensíveis às flutuações nos preços. Variáveis como a capacidade do fornecedor entregar os ativos requeridos na data correta, ou ainda corresponder às expectativas de desempenho, passam a assumir uma importância tão importante quanto a preocupação com o preço exato. Dessa forma, organizar uma série de transações por meio de um contrato certamente acarretará resultados diversos do que realizá-las no mercado à vista.

Ao que parece, o problema da seleção adversa é um dos principais inspiradores de Block. Um dos exemplos apresentados pelo autor, o da indústria da seda nos Estados Unidos, possui características que facilmente se enquadrariam na descrição feita por Akerlof (1970) para os mercados de carros usados. Em ambos os casos, a impossibilidade de checagem imediata do real desempenho dos atributos comercializados abre espaço para a trapaça por parte do agente com maior informação sobre o ativo. Consequentemente, a instituição de garantias solucionaria o problema de assimetria informacional, garantindo a realização dessas transações ${ }^{37}$.

Já o segundo contínuo apresentado por Block (1990) discute a possível ocorrência de comportamento instrumental nas ações econômicas. De acordo com o autor, a teoria neoclássica se equivoca ao não levar em consideração a existência de ações oportunistas nos mercados. Em outras palavras, esta é incapaz de fornecer uma explicação para o não cumprimento das regras legais por parte dos indivíduos. Com isso, tal paradigma

\footnotetext{
${ }^{37}$ Nesse sentido, a instituição de uma marca, por exemplo (BLOCK, 1990; BARZEL, 1982), emergiria como uma possível alternativa para intercâmbios com tais características. De fato, Barzel (2004) argumenta que dificuldades relacionadas à mensuração da qualidade dos ativos contribuem para a inexistência de um preço único. Assim, haveria uma clara relação entre a diminuição do grau de marketness em um mercado e a emergência de estruturas de governança alternativas a fim de organizar as atividades econômicas.
} 
tampouco apreende a face inversa desse fato, qual seja: o respeito dos agentes a normas sociais, ainda quando a trapaça seja factível.

Parcela considerável da crítica aos pressupostos adotados pela teoria neoclássica reside na suposta contradição entre a descrição dos indivíduos como maximizadores e a ausência de transgressões em uma sociedade. Apesar de trabalhos demonstrarem que o cálculo racional poderia ser aplicado inclusive à situações dessa natureza (BECKER, 1968), Block questiona a razão de muitos indivíduos não adotarem estratégias contrárias às regras vigentes, ainda que a probabilidade de detenção seja reduzida. Nesse sentido, o autor considera que tal realidade fornece um bom indicador da existência de enraizamento em um grupo social.

Tendo em vista esse quadro, Block complementa sua descrição para os distintos graus de marketness observados com a apresentação de um segundo contínuo. Nele, um dos extremos representa a adoção de um comportamento autointeressado nos mercados, algo que poderia culminar em ações oportunistas. Já a outra ponta demonstra o progressivo adensamento das relações sociais, cuja principal consequência é o estabelecimento da confiança entre os agentes. Sob tal contexto, variáveis como a religião, a família e a amizade teriam tanta importância quanto os preços na realização de transações.

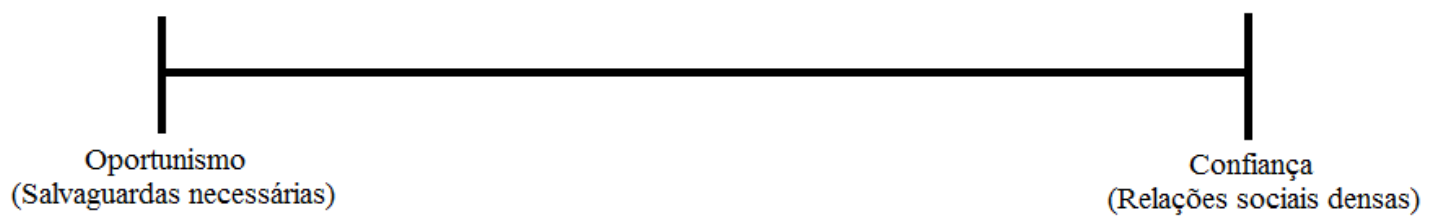

Figura 4: Block e a ocorrência de oportunismo nas transações econômicas FONTE: Baseado em Block (1990).

\subsection{Os contínuos de Block e a transferência de informações}

Concebidos com o objetivo de interpretar o nível de desregulamentação dos mercados nos EUA entre 1850 e 1950, os contínuos apresentados por Block (1990) podem ser adaptados para a análise de outras situações. Indo além, sua contribuição permite uma aproximação 
ainda maior à rotina dos agentes, enfocando as transações. Dessa maneira, é possível a utilização desse modelo para uma integração entre aspectos discutidos respectivamente pela ECT e por trabalhos ligados à sociologia econômica.

Antes de iniciar tal debate, porém, é importante esclarecer o papel dos preços na organização da rotina dos indivíduos. Afinal, a idealização da noção de enraizamento por muitos sociólogos contribuiu para o obscurecimento dessa questão (HINRICHS, 2000). Por isso, cabe esclarecer que a existência de estruturas sociais não leva ao abandono dos preços na tomada de decisões na esfera econômica. Pelo contrário, este parâmetro é levado em conta em todas as transações realizadas pelos indivíduos.

Da mesma forma, equivaler a consideração aos preços à falta de importância de outras variáveis fornece uma descrição empobrecida da realidade econômica. Inclusive, o argumento de que determinados mercados funcionariam baseados apenas no funcionamento do mecanismo de preços corresponderia a uma validação da ideia abstrata dessas estruturas. Ora, a existência dos mercados pressupõe a presença de estruturas sociais complexas (SMELSER; SWEDBERG, 1994). Nesse sentido, o próprio acesso aos preços decorre da organização dos humanos em torno de arranjos capazes de viabilizar o fornecimento desses dados.

Assim, a limitação da ECT não reside na relevância dada aos preços para o direcionamento das atividades econômicas, e sim em sua visão dos mercados. A existência de um contrato, por exemplo, se explica pela necessidade de garantir os investimentos realizados, e não para delimitar uma dimensão em que os preços não agiriam. Afinal, os indivíduos se baseiam nas informações fornecidas pelo mecanismo de preços a fim de direcionar os insumos para seu melhor aproveitamento. Entretanto, isso não significa que tais dados sejam detidos por todos os humanos de forma automática, ou ainda que o cálculo racional baste para explicar suas decisões.

De fato, nem mesmo o estabelecimento de um contrato garante a supressão de todos os problemas relacionados à assimetria informacional. Um acordo formal se destina a viabilizar o cumprimento das promessas feitas pelas partes; porém, inexistem garantias que assegurem a transferência de dados inalcançáveis a outros indivíduos. Nesse sentido, a 
consideração mais ampla das motivações humanas passa pelo reconhecimento de que podem faltar informações aos agentes em seu cotidiano econômico.

Em outras palavras, a busca pela maximização em um contexto marcado pela posse integral das informações relevantes torna a viabilização da cooperação o único motivo para o estabelecimento de estruturas de governança. Por outro lado, dificuldades para a obtenção desses dados não abririam espaço apenas para a adoção de estratégias oportunistas. Além disso, tal quadro possibilitaria a emergência de relações em que a transferência de informações por parte dos agentes ocorreria ainda que a outra parte não tivesse condições de obtê-las ${ }^{38}$.

Pois bem, os contínuos apresentados por Block (1990) auxiliam nesse debate justamente pela possibilidade de separação entre as características dos intercâmbios e as possíveis estratégias dos agentes. Mais especificamente, a dimensão dedicada ao estudo dos graus de marketness pode ser adaptada para a observação dos distintos níveis de especificidade dos ativos negociados em uma transação ${ }^{39}$. Já o contínuo relacionado ao aspecto comportamental se destinaria à análise das motivações dos indivíduos, sendo a transferência das informações ligadas aos resultados econômicos derivados da cooperação o principal indicador observado.

A fim de simplificar a apresentação dos argumentos, serão levadas em conta apenas as regiões próximas aos extremos dos contínuos. Dessa forma, a análise dos graus de marketness se concentrará em dois casos específicos, quais sejam: no primeiro, o mecanismo de preços é suficiente para organizar as transações, sendo que no outro, o estabelecimento de uma estrutura de governança alternativa faz-se necessária. Em relação ao contínuo dedicado às tendências comportamentais, as opções estarão limitadas à possibilidade de adoção de estratégias oportunistas ou à influência de outras motivações nas estratégias dos agentes.

\footnotetext{
${ }^{38}$ É importante salientar que a ECT se baseia na lógica da eficiência. Dessa maneira, o que está sendo aqui discutido é a distribuição da quase-renda derivada da cooperação econômica. Implicitamente, esse trabalho assume que ao menos uma das partes possui a capacidade de obter as informações necessárias a fim de destinar os insumos ao seu melhor uso.

${ }^{39}$ De acordo com Williamson (1991), há diferenças significativas entre uma forma híbrida e a organização por meio da firma. No entanto, o foco desse trabalho se encontra na questão da distribuição da quase-renda em relações estáveis, e não na análise dos mecanismos de solução de controvérsias existentes em cada arranjo organizacional. Com isso, tais diferenças não chegam a afetar as conclusões aqui apresentadas.
} 
Na primeira das situações, os intercâmbios são realizados em um mercado concorrencial. Resultado da interação de um número considerável de agentes, tais estruturas se caracterizam pelo oferecimento de ativos idênticos, transacionados por um preço único. Em tais casos, a eventual adoção de estratégias oportunistas passaria despercebida. Afinal, tal comportamento somente gera consequências do ponto de vista analítico quando resulta em perdas para outros indivíduos. Dito de outra forma, é somente quando agentes econômicos possuem algo idiossincrático a oferecer, almejando por este ativo um valor correspondente, que há espaço para a criação de expectativas em torno das atitudes de outros indivíduos em um intercâmbio.

Daí a importância da variabilidade para a consolidação desse pressuposto. O padeiro representado por Adam Smith (1993), por exemplo, poderia facilmente vender o seu produto a outro cliente caso fosse vítima de uma quebra de compromisso, dado que todos os seus concorrentes oferecem pães idênticos. Da mesma maneira, os consumidores não tem qualquer incentivo para escolher entre a padaria $\mathrm{X}$ ou $\mathrm{Y}$. Ao atravessar a rua e buscar os serviços de outro padeiro, o comprador irá se deparar com um produto exatamente igual àquele recusado anteriormente, de modo que sua perda reputacional ou mesmo de tempo jamais compensará tal ação.

Portanto, quando o mecanismo de preços é suficiente para organizar uma transação, os desdobramentos da adoção de estratégias oportunistas são insignificantes. Ademais, a interação entre um número considerável de humanos contribui para que custos de obtenção dos dados relevantes sejam reduzidos, possibilitando a participação de todos em condições semelhantes. Consequentemente, os indivíduos deverão receber aquilo que lhes cabe no intercâmbio, de modo que as contribuições e recompensas equivalham. A transferência de renda entre os agentes, apesar de constituir uma possibilidade, decorreria de uma decisão individual, e que não poderia ser explicada a partir da lógica da ECT.

Já a segunda possibilidade é aquela em que agentes com tendência a adotar um comportamento instrumental transacionam segundo as regras de uma estrutura de governança alternativa. À medida que arranjos organizacionais mais específicos passam a ser requeridos para organizar uma transação, diminui a capacidade dos arranjos convencionais de fornecer as informações relevantes. Com isso, resta aos indivíduos a 
busca pessoal por esses dados, a fim de determinar os resultados derivados da especialização produtiva.

Em muitos casos, as partes envolvidas tem condições de obter essa informação, de modo que a distribuição da quase-renda decorrente da cooperação corresponde às previsões da ECT. No entanto, naqueles casos em que algum dos agentes for incapaz de conseguir os dados relevantes para a determinação do valor de sua contribuição, a outra parte poderá agir de forma oportunista. Dito de outra forma, a recompensa paga pelo esforço do indivíduo desprovido de tais informações será menor do que o esperado caso todos fossem capazes de especificar sua participação no valor gerado a partir da coordenação consciente da produção.

De fato, quando uma das partes é incapaz de determinar o valor da quase-renda gerada a partir do investimento em ativos idiossincráticos, sua dependência em relação ao parceiro comercial é ainda maior. Nesse caso, os incentivos oferecidos para o engajamento em um arranjo cooperativo dependerá dos interesses daquele capaz de identificar as oportunidades de negócio. Evidentemente, a tendência é a de que tais incentivos sejam superiores àqueles disponíveis aos agentes em meio à interação no mercado commodity. Entretanto, nada garante que tal recompensa corresponderá ao valor da contribuição correspondente.

Por isso, a existência de motivações além do comportamento maximizador constituiria a principal explicação para a transferência dos dados relevantes nessa situação. Baseado no ferramental da ECT, a literatura vem demonstrando a importância da coordenação para a disseminação de informações capazes de garantir a adaptabilidade às demandas dos consumidores (WILLIAMSON, 1991; MENARD, 1996; ZYLBERSZTAJN, 1996). Indo além, é necessário levar em consideração as razões pelas quais tais informações chegam aos agentes. Da mesma forma como as preferências dos humanos não são transferidas automaticamente a todas as unidades produtivas, o quanto cada pessoa desejaria pagar por esses produtos tampouco é óbvio. 
Ao adotar o oportunismo como pressuposto comportamental, Williamson (1985, 1993a, 1993b) visa demonstrar o contraste entre o mundo descrito por diversos trabalhos e a realidade. Em sua opinião, a ECT se diferencia por identificar riscos subestimados em outras abordagens, permitindo o estabelecimento de garantias adequadas por parte dos agentes. No cenário descrito em sua contribuição, porém, é a variabilidade dos ativos a principal novidade introduzida, e cujas implicações são ainda subexploradas. Afinal, a linha tênue que separa a maximização do oportunismo está mais relacionada às possibilidades abertas aos agentes do que às características humanas em si.

Por isso, o estudo da organização econômica consciente deve se basear em uma concepção dos mercados distinta daquela utilizada pela teoria neoclássica. Dito de outra forma, é necessário um redimensionamento do papel do mecanismo de preços nas decisões dos agentes, de modo que sua evidente influência nas ações tomadas na esfera econômica não se confunda com um estado de onisciência humana. Inclusive, um olhar diferenciado sobre os mercados abriria espaço para a captura de mais detalhes relativos às estruturas de governança instituídas pelos humanos.

Nesse sentido, a análise da organização econômica deve ir além da verificação do alinhamento entre as características da transação e os arranjos estabelecidos. A validação dessa hipótese, embora seja um ponto de partida para o estudo do tema, não dá conta de uma série de questionamentos igualmente relevantes. Em especial, a ECT deve buscar seu refinamento a fim de observar com maior precisão a rotina em relacionamentos estáveis. Ou seja, o foco dado à minimização dos custos relacionados à administração dessas transações não pode ignorar as diferenças entre aqueles que a tornam possível.

Evidentemente, são diversos os fatores que determinam a distribuição da quase-renda em um intercâmbio. Por exemplo, a estrutura de mercado influencia diretamente a participação de cada indivíduo no valor total gerado, assim como a percepção dos consumidores acerca da contribuição dos agentes para o desempenho final do ativo (KAPLINSKY; FITTER, 2004; SAES, 2007, 2008). Dessa maneira, o presente trabalho busca acrescentar novos elementos ao debate, chamando a atenção para a insuficiência da 
noção de custos de transação adotada pela ECT. Além disso, tal contribuição possibilitaria a apreensão das motivações dos humanos em sua ação econômica ignoradas pela abordagem de Williamson. 


\section{SERÁ A JUSTIÇA SUFICIENTE? O PAPEL DA QUALIDADE NO \\ SISTEMA FAIRTRADE}

\subsection{O problema}

O selo Fairtrade mensura atributos sociais relacionados à produção agrícola, estabelecendo um preço mínimo para as transações levadas a cabo de acordo com suas regras. Concebido com o objetivo de garantir uma melhor remuneração a cafeicultores familiares $^{40}$, este sistema vem lidando, desde sua origem, com um excesso de oferta que inviabiliza a participação de todos os produtores certificados. De fato, não raramente as cooperativas detentoras do selo Fairtrade tem de recorrer a canais convencionais para a venda de sua produção, algo que as priva dos benefícios previstos pela certificação.

Tendo em vista esse quadro, a seguinte questão será aqui discutida: $\boldsymbol{O}$ que garante $\boldsymbol{a}$ inserção das cooperativas detentoras do selo Fairtrade no mercado originado com a certificação? Indo além, o presente trabalho fornecerá uma interpretação alternativa para a dinâmica observada no comércio justo ${ }^{41}$, enfatizando a necessidade de integrar aspectos teóricos e empíricos para o estudo desse mercado. Nesse sentido, o principal argumento desenvolvido nas próximas páginas é o de que o foco das análises existentes nas regras estabelecidas pela certificação Fairtrade tem contribuído para uma visão imprecisa acerca do funcionamento desse sistema.

Afinal, a capacidade dos agentes de perseguirem os seus interesses a partir das normas existentes, readequando suas estratégias segundo o contexto, é considerável. Ao se limitar à certificação dos produtos, as organizações responsáveis pela disseminação do comércio justo abriram espaço para a livre coordenação entre os agentes, algo que acentuou o sucesso de determinadas cooperativas em detrimento da exclusão de outras. Dessa

\footnotetext{
${ }^{40}$ Em sua origem, a certificação solidária visava auxiliar cafeicultores familiares em dificuldades econômicas. No entanto, ao longo da década de 90 tal modelo foi ampliado a uma série de outros produtos agrícolas. Para uma apresentação da história do comércio justo, ver Jaffee (2007).

${ }^{41}$ O selo Fairtrade corresponde a apenas uma das vertentes ligadas ao movimento comércio justo. Dessa maneira, é importante salientar que tal certificação constitui o foco desse trabalho. Atividades como aquelas desevolvidas por organizações ligadas à World Fair Trade Organization (WFTO), embora sejam parte do comércio justo, não serão aqui consideradas.
} 
maneira, a mera consideração dos princípios vinculados ao sistema Fairtrade fornece uma descrição empobrecida da realidade por trás desse mercado.

O debate acerca da inserção mercadológica no sistema Fairtrade é vital devido à centralidade do preço mínimo no funcionamento do selo. Segundo Raynolds (2002), apenas $30 \%$ do café certificado produzido no México era vendido pela cotação estabelecida pela FLO no início do século XXI. Com isso, parcela considerável dos produtores ligados ao Fairtrade não tem acesso ao principal benefício derivado da adoção do selo, qual seja, a garantia de uma remuneração superior àquela oferecida pelo mercado internacional $^{42}$.

Portanto, compreender os motivos que levam determinadas cooperativas a obterem sucesso nesse segmento constitui uma tarefa tão importante quanto o dimensionamento das vantagens derivadas do comércio justo. Embora outros benefícios relacionados à participação no Fairtrade, como a organização política dos cafeicultores (PIROTTE; PLEYERS; PONCELET, 2006), sejam também importantes, é evidente que estes somente se sustentam no longo prazo caso os recursos financeiros disponíveis o permitam.

Assim como na grande maioria dos trabalhos dedicados ao tema, o foco deste artigo será a cafeicultura, cuja importância para o sistema Fairtrade é considerável. De acordo com a FLO (2007), as vendas de café certificado atingiram 52.077 toneladas métricas em 2006, um aumento de 53\% em relação ao ano anterior. Baseadas em quase trinta países, cerca de 250.000 pessoas se encontram diretamente envolvidas na produção e comercialização do produto, consumido principalmente na Europa Ocidental e na América do Norte (GIOVANNUCCI; LIU; BYERS, 2008; TRANSFAIR, 2007).

A hipótese norteadora desse trabalho é a de que as cooperativas caracterizadas pela produção de café com qualidade superior conseguirão vender uma porcentagem superior de sua safra total pelo preço Fairtrade. De certa maneira, esta proposição se encontra embutida nos principais estudos dedicados ao tema (RAYNOLDS, 2002; TAYLOR,

\footnotetext{
${ }^{42}$ Obviamente, o Fairtrade vai além do oferecimento de um preço superior àquele praticado no mercado convencional. Benefícios como o financiamento prévio da colheita, o prêmio social ou o intercâmbio de informações constituem práticas importantes desse sistema. Porém, tais vantagens se encontram restritas àqueles produtores capazes de vender no segmento Fairtrade, de modo que o recebimento do preço mínimo e o acesso aos benefícios adicionais da certificação solidária estão relacionados.
} 
2002), ainda que sua discussão seja insuficiente. Conforme já dito, a principal razão para tal quadro é a relativa desconexão entre a busca por uma fundamentação teórica para o Fairtrade e a observação dos fatos nesse sistema.

O ferramental utilizado no debate a seguir será aquele proporcionado pela Teoria dos Custos de Mensuração (TCM), resultante do trabalho de Yoram Barzel (1982, 1997, 2004). Apesar de estar assentada em uma perspectiva semelhante àquela utilizada por outros trabalhos sobre o tema, de cunho microanalítico, tal abordagem permite uma apreensão mais adequada dos aspectos relacionados à ação discricionária dos agentes. Evidentemente, o diálogo com os principais estudos dedicados ao Fairtrade será uma constante ao longo de todo o texto, de modo a demonstrar alternativas para a pesquisa sobre o tema.

\subsection{O Fairtrade e a academia: principais contribuições prévias}

Desde seu surgimento, em meados do século XX, o comércio justo constitui uma espécie de resposta prática às consequências negativas de eventos políticos. Mais especificamente, inexiste uma teoria geral que fundamente o comércio justo (MOORE, 2004). Nesse sentido, as diversas ações amparadas em tal noção não seguem um corpo de ideias específico. Grupos com orientações variadas, como os partidos de esquerda na Europa Ocidental e os menonitas nos EUA, estão vinculados às origens do movimento, dando interpretações particulares para suas atividades.

Assim, um complexo pano de fundo emerge por trás do Fairtrade, sendo notáveis as mudanças em sua estrutura ao longo do tempo. Originalmente, o comércio justo se baseava na venda de artesanato produzido por comunidades empobrecidas, contando para isso com uma considerável rede de distribuição alternativa ${ }^{43}$. Com isso, as organizações políticas envolvidas nessa atividade desde o fim da II Guerra Mundial foram, durante praticamente

\footnotetext{
${ }^{43}$ No antigo formato, não apenas as nações do Terceiro Mundo eram beneficiadas, como também povos afetados por conflitos armados ou ainda comunidades empobrecidas em países com alta renda per capita. Exemplos dessa atuação podem ser encontrados no trabalho dos menonitas junto a comunidades do Sul dos Estados Unidos, ou ainda no auxílio aos gregos após o final da II Guerra Mundial. Ver Jaffee (2007).
} 
quatro décadas, responsáveis pela comercialização dos artigos produzidos por habitantes de todos os cantos do globo.

Na década de 80 , porém, o interesse de uma comunidade indígena mexicana ${ }^{44}$ no aumento de suas exportações acaba abrindo espaço para o estabelecimento do sistema de certificação para a cafeicultura familiar. O resultado mais visível dessa nova fase do comércio justo é a proliferação das chamadas iniciativas nacionais, dedicadas a organizar a certificação e engajar os agentes nos mais diversos níveis. Como consequência desse movimento, em 1997 é fundada a Fairtrade Labelling Organizations (FLO), cujo objetivo é o de garantir a padronização das regras para esse mercado.

Dessa forma, de um papel ativo no contato com fornecedores e consumidores, as iniciativas voltadas ao comércio justo passam a assumir um caráter eminentemente regulador. Nessa nova fase, um número considerável de produtores passa a ser integrado ao novo sistema, gerando fluxos de comércio crescentes. A agilidade proporcionada pelo estabelecimento da certificação permitiu a rápida expansão da produção Fairtrade, que passou a frequentar as gôndolas das grandes redes de supermecado e lojas especializadas.

Paralelamente, o início dos anos 90 testemunha a publicação dos primeiros trabalhos dedicados a compreender o comércio justo. Entretanto, não são raros os casos em que as figuras do analista e do militante se confundem (BROWN, 1993), de modo que o debate em diversos momentos se pauta pelas promessas derivadas desse movimento. Com isso, levaria algum tempo até que os esforços direcionados à construção de uma visão menos apaixonada do Fairtrade dessem seus frutos (TAYLOR, 2002; JAFFEE, 2007). Baseados principalmente na sociologia, esses estudos buscam apontar as motivações para o estabelecimento de um mercado com características distintas daquelas descritas pelos manuais de economia.

De fato, a dificuldade para a compreensão da dinâmica do Fairtrade entre os economistas é considerável. Afinal, muitas das práticas associadas ao comércio justo vão de encontro com as políticas defendidas por analistas amparados no ferramental neoclássico. Mann (2008), por exemplo, afirma que o estudo da lógica por trás do Fairtrade é fundamental,

\footnotetext{
${ }^{44}$ O caso em questão é o da UCIRI, uma cooperativa baseada no estado mexicano de Oaxaca, e que em 1988 motivou a constituição do selo Max Havelaar, na Holanda. Ver Fridell (2007).
} 
dado que a existência de um mercado que demanda melhores preços sem o oferecimento de qualidade física é algo sem precedentes. Outros autores, como Zehner (2002) apontam os supostos incentivos perversos resultantes do estabelecimento de um preço mínimo, enfatizando os impactos dessa política sobre a qualidade final dos produtos certificados.

$\mathrm{Na}$ verdade, tal dificuldade se deve ao sentido que um debate acerca da justiça possui para as ciências econômicas. Dependendo da perspectiva teórica adotada, tal clamor soaria descabido, principalmente se é levada em conta a força que a idéia da divisão do trabalho possui no desenvolvimento das ciências sociais desde o fim do século XVIII. Sua consolidação em torno de um quadro idealizado, marcado pela harmonia social, deixa pouco espaço para a emergência de questões como aquelas levantadas pelos principais defensores de mecanismos alternativos de comercialização de bens, tal como o Fairtrade.

Assim, parcela considerável das análises do sistema Fairtrade se assenta sob um olhar crítico à divisão do trabalho, em especial no relacionamento entre sociedades. Exemplos dessa abordagem são encontrados na retomada das teses cepalinas de meados do século $\mathrm{XX}$, dedicadas a fornecer uma interpretação estruturalista das relações comerciais internacionais (KONING; CALO; JONGENEEL, 2004; FRIDELL, 2007), ou ainda na utilização de uma perspectiva voltada a apreender a dinâmica de geração e distribuição de valor ao longo das cadeias de commodities (DAVIRON; PONTE, 2005; RAYNOLDS; WILKINSON, 2007).

Nos estudos supracitados, uma característica comum pode ser identificada, independentemente da vinculação teórica, qual seja: a identificação de alegadas falhas nas formas tradicionais de comercialização de produtos agrícolas. Nesse sentido, a apresentação do Fairtrade costuma vir acompanhada de certa idealização, dado que o sistema é visto como uma resposta direta às práticas comerciais vigentes. Tal viés é percebido, por exemplo, na considerável atenção dada aos princípios do comércio justo, geralmente em detrimento de uma análise mais detida de seu funcionamento.

Essa tendência é observada sobretudo nas visões mais ambiciosas do Fairtrade. Para um grupo de autores (RAYNOLDS, 2000; RENARD, 2003, 2005; TAYLOR, 2005), o comércio justo é uma proposta de transformação radical das relações comerciais internacionais, agindo na conscientização de consumidores e comerciantes acerca da 
necessidade da construção de um relacionamento diferenciado com os produtores rurais do Terceiro Mundo. Em meio à referência aos principais mecanismos estabelecidos pelo sistema Fairtrade, o que essa corrente busca demonstrar é o caráter alternativo de um projeto que, no longo prazo, visa suplantar as formas tradicionais de comercialização de bens.

Entretanto, o alcance analítico dessas obras se mantém limitado à apreciação das intenções esboçadas nos documentos divulgados pelas ONGs fomentadoras do Fairtrade, sem maior espaço para um aprofundamento no cotidiano do mercado certificado. Quando realizada, a avaliação das mudanças trazidas pela instituição do selo para a realidade dos agricultores costuma ser feita de forma desintegrada das interpretações teóricas para o movimento. Afinal, esses estudos (RAYNOLDS, 2002b; TAYLOR, 2002) apresentam evidências de que as cooperativas mais exitosas no segmento Fairtrade possuem características semelhantes àquelas inseridas no mercado convencional.

Em parte, tal dificuldade em lidar com os resultados do comércio justo se deve à forma adquirida por esse sistema após a instituição do selo Fairtrade. Um mercado governado por determinado padrão privado, como uma certificação, tende a assumir características próximas às de uma concorrência perfeita, especialmente em casos nos quais a mensuração dos atributos relevantes seja realizada de forma perfeita (BARZEL, 2004). Ou seja, sua organização pode se dar de forma bastante semelhante àquela prevista pelo modelo de equilíbrio geral, de modo que visões críticas do sistema econômico internacional seriam seriamente enfraquecidas.

Por isso, uma segunda corrente vem ganhando força nos últimos anos, ao defender a tese de que o Fairtrade é uma tentativa de corrigir falhas de mercado do sistema comercial convencional (NICHOLLS; OPAL, 2004). De acordo com esses autores, mais que uma ruptura com a ordem vigente, o que o comércio justo busca é a criação de instrumentos que possibilitem um funcionamento mais adequado do mercado, garantindo a melhoria da situação dos produtores rurais baseados nos países em desenvolvimento. Assim, pode-se dizer que, ao invés de desacreditar completamente o potencial dos mercados convencionais na promoção do bem-estar social, esses estudos demonstram que a correção de desvios seria suficiente para a conformação de um quadro favorável. 
Transformador ou uma proposta de adaptação, o fato é que o Fairtrade possui um considerável componente ético em sua constituição. Dessa maneira, tão importante como a dúvida acerca das intenções do comércio justo é a identificação dos principais beneficiados com a instituição desse sistema. Inclusive, é possível afirmar que ambas as preocupações se encontram diretamente relacionadas: uma crítica à forma como se dá o comércio internacional de commodities, por exemplo, é resultado da discordância quanto aos resultados proporcionados por esse modelo, bem como as estratégias empregadas por seus participantes. Nesse sentido, tratar do comércio justo se refere não apenas às suas intenções, mas também aos seus resultados.

Via de regra, essa relação não é devidamente explorada, sendo notável a abordagem separada dos princípios do Fairtrade e suas consequências mais evidentes. Tal lacuna se deve, em primeiro lugar, à predominância de estudos de caso na análise das cooperativas certificadas, opção que não permite um olhar sobre características gerais do segmento. Além disso, a estruturação do selo em torno de aspectos sociais faz com que falte espaço para uma discussão que integre o papel da diferenciação entre os produtores aos objetivos do Fairtrade. Ora, em um sistema no qual todos os agentes compartilham os mesmos ideais e os atributos relevantes são perfeitamente mensurados, qual a diferença entre a aquisição de agente A ou B?

\subsection{Fairtrade e análise econômica: um falso anátema}

Devido à busca por uma teoria capaz de explicar o selo Fairtrade, os principais estudos dedicados ao tema se baseiam em abstrações que marcam as diferenças entre esse sistema e os mercados convencionais. Nesse sentido, tais análises salientam a insuficiência do ferramental neoclássico para a compreensão dos fenômenos econômicos, lançando mão das mais diversas alternativas para suprir essas lacunas. Abordagens baseadas na teoria das convenções (WILKINSON, 1997, 1999), por exemplo, são comuns nos trabalhos voltados ao comércio justo.

O principal mérito da teoria das convenções reside no reconhecimento de que o preço não constitui a única informação relevante para um grande número de transações 
(WILKINSON, 1999; RAYNOLDS; WILKINSON, 2007). Pelo contrário, a organização dos mercados dependeria da construção social de uma noção de qualidade, cujo significado variaria de acordo com os anseios dos agentes. Mais especificamente, essa abordagem aponta a importância da ação coletiva para a instituição de padrões (RENARD, 2005), muitos dos quais ligados a valores ignorados pela economia neoclássica.

Assim sendo, tais estudos tem fornecido uma interpretação satisfatória para o processo de estabelecimento da certificação Fairtrade. No entanto, deixam a desejar quando requeridos a descrever a rotina nesse sistema. Em grande parte, tal limitação se deve à dificuldade de apreensão, por parte da teoria das convenções, de aspectos ligados às estratégias individuais dos agentes. Ainda que as preferências pessoais sejam levadas em conta por essa abordagem, a construção social de um mercado parece ser o único objetivo perseguido pelos humanos.

Com isso, a teoria das convenções concede demasiada atenção aos responsáveis pela administração dos mercados originados a partir da identificação de uma qualidade (TAYLOR; MURRAY; RAYNOLDS, 2005; RENARD, 2005). Concepções diferentes acerca do conteúdo desses arranjos eventualmente originariam conflitos, levando à sua reorganização. Porém, o formato de tais construções sociais corresponderia às demandas dos agentes detentores de seus mecanismos de acesso e exclusão. Um mercado seria, portanto, reflexo da concepção daqueles que o controlam.

No mundo real, porém, a distância entre os idealizadores de um determinado segmento e as práticas observadas em seu interior pode ser considerável. Em muitos casos, a definição de qualidade vigente nos mercados não chega a ser abertamente desafiada, dado que as normas impostas pelos administradores desses arranjos garantem espaço suficiente para uma adequação das estratégias dos agentes. Além disso, a discordância acerca dos objetivos perseguidos em um intercâmbio constitui uma possibilidade real, abrindo espaço para a conformação de uma realidade além das regras formais.

Por outro lado, o desconforto de muitos economistas ao tratar do sistema Fairtrade evidencia a falta de instrumentos adequados para a análise desse tipo de mercado. Entretanto, tal dificuldade não se deve à suposta proposta transformadora do comércio justo, no sentido de distanciar o cotidiano econômico das previsões feitas pela teoria 
neoclássica (MURRAY; RAYNOLDS, 2007). Afinal, as limitações para o estudo de uma certificação são consideráveis mesmo quando é assumida a presença de agentes maximizadores no cenário descrito.

Historicamente, a existência de padrões não tem recebido atenção adequada por parte da literatura econômica (BARZEL, 2004). Em grande parte, tal negligência é motivada pelos pressupostos teóricos utilizados na análise dos mercados pela microeconomia neoclássica. Nesse sentido, o fato dessa visão considerar que os bens transacionados em um dado mercado são idênticos, ou que a delimitação perfeita dos direitos de propriedade é realizada sem qualquer custo, torna a existência de uma certificação, por exemplo, irrelevante para o cotidiano econômico.

Dessa maneira, as críticas feitas pelos principais estudos dedicados ao Fairtrade à incapacidade da teoria neoclássica de explicar esse mercado são incompletas. Na verdade, a dificuldade desse ferramental de abordar o comércio justo não se deve às motivações de seus participantes, e sim ao fato de que os sistemas de certificação possuem características desconsideradas pela maioria dos economistas. Tanto isso é verdade que abordagens destinadas a demonstrar a proximidade entre o mundo descrito pela microeconomia e o selo Fairtrade (NICHOLLS; OPAL, 2004) tampouco dão conta da tarefa de explicar a dinâmica nesse segmento.

Uma certificação deve ser analisada com base na forma como seus usuários a utilizam. Em contraste, o debate acerca da viabilidade do sistema Fairtrade tem se resumido aos efeitos decorrentes da cotação mínima sobre os produtores (ZEHNER, 2002; YANCHUS; DE VANSSAY, 2003; MASELAND; DE VAAL, 2008). Considerações acerca do real significado dessa política para a reacomodação das estratégias dos agentes são raras (JAFFEE, 2007, 2008; RAYNOLDS, 2002), e quando feitas não se conectam à interpretação dada para a existência do selo. Por isso, o avanço na compreensão da realidade do comércio justo passa pelo desenvolvimento de ferramentas mais adequadas para o entendimento de mercados governados por uma certificação.

Para tanto, é fundamental que se tenha em vista o problema fundamental associado a essa forma de organização econômica, qual seja: aquele ligado à mensuração dos atributos relevantes dos ativos transacionados. Em linhas gerais, é este o principal motivo para o 
estabelecimento de uma certificação, sejam quais forem as suas características. A partir da análise de tal tópico, uma série de outras questões podem ser melhor abordadas, como a referente às estruturas de governança encontradas nos intercâmbios realizados. Embora alguns trabalhos (TAYLOR, 2002) descrevam os arranjos organizacionais existentes no mercado Fairtrade, é necessária uma maior comunicação entre a rotina nesse segmento e as explicações teóricas para sua existência.

Responsável pelo desenvolvimento de uma vertente teórica dedicada ao estudo do problema da mensuração, Barzel $(1982,2000,2004)$ oferece importantes elementos para um melhor entendimento dos sistemas de certificação. Amparada em uma perspectiva microanalítica, a teoria dos custos de mensuração (TCM) permite uma abordagem mais completa desses mercados, justamente pelo foco na interação entre os usuários dos selos. Igualmente, tal abordagem permite a formulação de hipóteses para a análise das estruturas de governança existentes nesses mercados, relacionando-as com os atributos transacionados entre os agentes.

\subsection{A TCM e os direitos econômicos de propriedade}

A importância dos padrões só passa a ser devidamente apreendida pela literatura econômica a partir do momento em que as razões para seu estabelecimento são introduzidas no debate. Em especial, o reconhecimento de que bens visualmente idênticos entre si podem apresentar diferenças significativas quanto aos seus atributos levou a um interesse crescente nos desdobramentos de tal fato ${ }^{45}$. Desde então, trabalhos tem lidado com temas como o papel da variabilidade para a governança das transações (BARZEL, 1982, 1997, 2000), ou ainda os fatores de risco por trás da decisão de produção de ativos dotados de algum diferencial (KLEIN; CRAWFORD; ALCHIAN, 1978; WILLIAMSON, 1985).

\footnotetext{
${ }^{45}$ É importante lembrar que a vertente teorica a qual se filiam os trabalhos de Williamson e Klein, Crawford e Alchian se dedica a uma forma de variabilidade dos ativos distinta daquela observada por Barzel. Para o primeiro grupo de autores, a principal variável considerada é o investimento específico, ao passo que para a TCM a informação acerca das características dos ativos constitui o foco analítico.
} 
Uma das vertentes originadas a partir da adoção da variabilidade dos ativos como pressuposto teórico é a chamada teoria dos custos de mensuração (TCM), baseada na contribuição de Yoram Barzel. Segundo esse autor, um ativo pode ser visto como um conjunto de atributos, cujos níveis de qualidade variam, sendo seu valor total o resultado da somatória dos valores de cada um desses atributos (BARZEL, 2000). Assim, a principal consequência da existência da variabilidade entre os ativos é a necessidade constante de mensuração de seu valor.

Por se tratar de uma atividade que consome o tempo dos indivíduos, a mensuração dos atributos não é gratuita, e por isso os agentes econômicos buscarão economizar nesta atividade sempre que considerarem possível fazê-lo (BARZEL, 1982). Igualmente, os custos de mensuração de cada um dos atributos pertencentes a um ativo são crescentes, o que torna a determinação do valor total de um bem inviável na maioria dos casos (BARZEL, 2000). Dessa maneira, é evidente a limitação do papel do Estado na garantia dos direitos de propriedade.

Afinal, o judiciário tende a garantir integralmente somente aquelas transações cujas características lhe são familiares (BARZEL, 2004). Baseado em tal quadro, o autor apresenta a noção de direito econômico de propriedade, que complementa aquele de natureza legal. Segundo Barzel (1997), os direitos legais se encontram diretamente ligados às garantias estatais à propriedade privada, seja por meio da polícia ou do sistema judiciário. Por sua vez, os direitos econômicos se relacionam aos esforços pessoais para a manutenção da posse efetiva sobre um ativo.

Fundamental para Barzel (1994) é a ideia de habilidade, que consiste na capacidade individual para o aproveitamento direto ou indireto dos ativos possuídos. Nesse sentido, a definição de direito econômico de propriedade está relacionada àquilo que os agentes acreditam poder fazer com seus ativos, e não às garantias legais concedidas. Isso não significa, porém, que os direitos econômicos independam das condições oferecidas pelo Estado para sua proteção. De fato, considerações de ordem legal constituem parte do cálculo realizado pelos indivíduos a fim de determinar a forma como utilizarão seus ativos (FOSS; FOSS, 2001). 
Assim, os direitos econômicos, apesar de inconstantes, dependem não apenas do esforço pessoal de proteção, como também das tentativas de captura por parte de outros agentes e das garantias governamentais (BARZEL, 1997). Eventualmente, a presença de altos custos de mensuração faz com que os indivíduos não exerçam os direitos econômicos sobre atributos de seus ativos. Nesses casos, tais características são deixadas no chamado domínio público, dimensão em que a apropriação de um atributo não acarreta a remuneração de agente algum. Pelo contrário, os recursos gastos para tal objetivo são direcionados exclusivamente para a superação das limitações impostas pela existência desses custos de mensuração.

Para o exato entendimento daquilo que viria a ser o domínio público, é fundamental considerar que, sob a perspectiva de Barzel (1997), a análise walrasiana não aborda todas as margens que poderiam ser exploradas pelos agentes. Em especial, o autor chama a atenção para o valor econômico do tempo de espera (BARZEL, 1974, 1997), algo que poderia ser capturado por indivíduos cientes dessa realidade. Da mesma maneira, o tempo utilizado para a mensuração dos atributos de um ativo (BARZEL, 1982, 2000) poderia ser considerado um gasto passível de captura.

Dito de outra forma, tanto o tempo de espera quanto aquele usado a fim de mensurar o desempenho estão relacionados ao delineamento dos direitos econômicos de propriedade sobre um ativo. Não por acaso, Barzel (1997) define os custos de transação como o custo associado à transferência, captura e proteção de direitos. Ou seja, as noções de direito econômico de propriedade e custo de transação, na visão da TCM, estão intimamente ligadas. Sob a mesma lógica, a má definição dos direitos econômicos de propriedade, e a consequente presença de atributos no domínio público pode acarretar a dissipação desse valor $^{46}$.

Portanto, a base do raciocínio de Barzel está na ideia de que uma transação é constituída pela troca de informações acerca dos atributos pertencentes a um ativo (CALEMAN et al., 2006). Aquelas características de fácil mensuração, e que consequentemente são conhecidas por todos, podem ser garantidas por meio do aparato legal existente. Já os

\footnotetext{
${ }^{46}$ Segundo Cheung (1974), quando o direito de obter rendas de um ativo é parcialmente ou totalmente retirado de uma parte contratante, haverá a tendência à dissipação desse valor. Tal quadro se materializaria, por exemplo, na utilização ou produção inadequada do bem em questão.
} 
atributos cujos gastos de mensuração sejam altos dependem de outras formas de garantia, sendo indispensável a proteção individual. Em diversos casos, tal realidade fará com que determinados atributos sejam deixados no domínio público, devido aos custos de proteção envolvidos.

No médio prazo, tal quadro contribuiria para que determinados atributos deixassem de ser oferecidos no mercado. Com isso, o estabelecimento de estruturas de governança emerge como uma alternativa para a garantia de fornecimento de atributos de difícil mensuração. Barzel (2002) argumenta que a escolha dos mecanismos de controle adotados em uma transação dependerá de uma série de fatores, quais sejam: i) o custo de mensuração dos atributos relevantes; ii) os gastos relacionados à constituição de um relacionamento de longo prazo; iii) a capacidade do Estado de garantir contratos; e iv) o número de intermediários no processo de disseminação das informações.

Em sua totalidade, a TCM se propõe a uma série de objetivos, entre as quais a definição daquilo que viria a ser uma firma ${ }^{47}$. Nesse sentido, Barzel oferece inúmeras alternativas organizacionais delineadas segundo a preocupação central de sua abordagem, qual seja: a maximização do valor da transação (ZYLBERSZTAJN, 2005a) De acordo com os objetivos do presente trabalho, entretanto, é suficiente a diferenciação entre os modos de governança observados no intercâmbio de atributos com niveis de custo de mensuração insuficientes a ponto de justificar uma integração vertical.

Para aqueles atributos cuja mensuração é considerada fácil, o recurso aos contratos tende a prevalecer. Afinal, a relativa facilidade encontrada para a determinação dos deveres das partes torna a utilização de acordos formais garantidos pelo Estado a melhor opção para a governança das transações. Dessa maneira, Barzel (2004) afirma que tais mercados constituem o principal ponto de aproximação entre a microeconomia neoclássica e o mundo real. Conforme será mostrado a seguir, segmentos organizados em torno de uma certificação podem assumir tais características, ainda que a mediação de terceira parte escolhida não seja necessariamente aquela proporcionada pela autoridade estatal.

\footnotetext{
${ }^{47}$ Para uma interpretação da firma sob a lógica da TCM, ver Barzel (2001).
} 
Por outro lado, o estabelecimento de relações de longo prazo emerge como uma alternativa para a garantia do fornecimento de atributos de difícil mensuração. Aqui, conforme salientado por Barzel (1994, 2000), a capacidade do Estado em garantir o cumprimento desse tipo de contrato é limitada, devido às dificuldades de delimitação das obrigações de cada parte no intercâmbio. Por isso, a tendência é a de que a reputação seja a principal responsável pelo bom andamento da relação, já que problemas de desempenho do fornecedor poderiam ser punidos com a troca de parceiro para futuras transações.

As marcas, por exemplo, são claras manifestações do quadro supradescrito. Do ponto de vista dos consumidores, tais sinais diferenciais constituem uma garantia da qualidade dos produtos adquiridos, possibilitando a economia de recursos na mensuração dos atributos relevantes (BARZEL, 1982). Na relação entre fornecedores e intermediários, a lógica predominante é semelhante. Nesse sentido, a reputação de um produtor agrícola serviria como uma prova de que os produtos transacionados possuem as características demandadas, algo que garante um menor gasto na checagem das promessas realizadas no momento anterior ao intercâmbio.

\subsection{O estabelecimento de uma certificação e o problema da inserção}

Um padrão consiste em um conjunto de especificações técnicas, termos, definições e princípios de classificação e certificação, cuja principal função é a de garantir a consecução de determinado objetivo (REARDON; FARINA, 2001). Sua instituição é decorrente da queda nos custos de mensuração de um atributo relevante para determinado grupo de transações (BARZEL, 2004). Dessa forma, a emergência de novos padrões se encontra diretamente ligada a processos de inovação, estejam estes ligados à esfera institucional ou tecnológica.

Padrões são responsáveis pela economia de recursos, dado que disponibilizam informações anteriormente restritas aos agentes detentores dos ativos, tornando-as um bem público (BARZEL, 2004). Em outras palavras, o tempo gasto em atividades ligadas à mensuração de um bem diminui sempre que um padrão seja capaz de fornecer dados confiáveis acerca dos atributos relevantes aos agentes. Consequentemente, alternativas visando a redução 
dos custos em tal ação, como a existência de marcas e garantias, perdem importância nesses mercados.

Com a instituição de um padrão, há a tendência dos mercados assumirem características bastante próximas de uma concorrência perfeita. Isso se deve a uma maior capacidade de mensuração, algo que garante a aproximação entre a qualidade dos ativos transacionados. Assim, é esperado um aumento na ocorrência do uso de contratos para a governança das transações realizadas em mercados organizados a partir de um padrão (BARZEL, 2004). Igualmente, ganha importância o papel do Estado no cumprimento desses acordos, haja vista a possibilidade de especificação dos atributos relevantes nos acordos formais celebrados pelas partes.

Entretanto, cabe salientar que a suposta proximidade entre tais mercados e o modelo de concorrência perfeita apresentado pela microeconomia neoclássica pode estar limitada a aspectos relacionados à governança e inserção dos agentes. Tal fato é especialmente verdadeiro para os padrões privados de qualidade, dado que estes se voltam à exploração de oportunidades de diferenciação nos mercados agroalimentares (HENSON; REARDON, 2005). Dessa maneira, uma certificação pode ter o objetivo de delimitar um segmento de mercado, a fim de viabilizar a obtenção de lucros econômicos ${ }^{48}$.

Nesse sentido, a natureza política dos mercados regulamentados por uma certificação privada não pode ser esquecida. Em tais arranjos, os direitos legais são estabelecidos não apenas pelo Estado, como também pela organização responsável pela fixação dos critérios para a concessão do selo. De acordo com Renard (2005), o estabelecimento de uma certificação origina uma fonte de poder, dado a prerrogativa de controle concedida aos seus administradores. Essa posição privilegiada deriva da capacidade que estes possuem de permitir a entrada e exclusão de agentes de tal segmento.

Indo além, nem mesmo os padrões instituídos pela autoridade estatal se encontram livres das pressões políticas. Inclusive, o estabelecimento das normas ligadas à definição dos direitos de propriedade ou das regras de troca em um mercado é diretamente condicionado

\footnotetext{
${ }^{48}$ Ainda segundo Henson e Reardon (2005), os padrões estabelecidos pela autoridade estatal lidam, em geral, com questões relativas à sanidade animal ou vegetal, de modo que sua atuação gera um bem público.
} 
pelos anseios dos agentes de mitigarem os efeitos da concorrência ${ }^{49}$ (FLIGSTEIN, 1996). Porém, entre as unidades inseridas nas regras vigentes, a obediência a requisitos idênticos torna sua inserção mercadológica motivada por forças semelhantes àquelas observadas em um modelo de concorrência perfeita.

Tal realidade é especialmente materializada naquelas situações em que a existência de uma certificação garanta a mensuração perfeita dos atributos relevantes ${ }^{50}$. De fato, um mercado em que as regras para a participação estejam bem definidas não apresenta qualquer atalho para que A ou B garantam sua inserção. Para casos em que o preço é determinado pela livre interação entre os agentes, os resultados individuais colhidos derivam desse intenso movimento. Já naqueles segmentos em que haja excesso de oferta devido a um controle de preços, a escolha de um parceiro para a transação se dá de forma absolutamente aleatória.

Evidentemente, tal conclusão não implica a despersonalização absoluta do processo de intercâmbio de bens. Afinal, determinados segmentos podem se caracterizar justamente pelo oferecimento dessa interação entre produtores e consumidores ${ }^{51}$. O aspecto fundamental a ser apreendido aqui é o de que mercados caracterizados por um grande número de agentes dotados de características idênticas tendem a ser organizados de forma semelhante a uma concorrência perfeita. Assim, as estruturas de governança utilizadas por tais indivíduos deverão corresponder àquelas descritas em tal modelo, bem como a natureza de sua inserção.

Por outro lado, a emergência de relações de longo prazo em segmentos instituídos em torno de uma certificação se explicaria pela necessidade de fornecimento de atributos não mensurados sob tais regras. Características de difícil verificação no momento do intercâmbio são exemplos desse quadro. Com isso, é possível que um selo garanta apenas

\footnotetext{
49 Para um grupo considerável de economistas, o estabelecimento dos direitos de propriedade em uma sociedade poderia ser explicado segundo a lógica da eficiência (DEMSETZ, 1967). No entanto, o avanço nas pesquisas (EGGERTSSON, 1990; FLIGSTEIN, 1996) tem demonstrado que considerações de ordem política ou cultural são fundamentais para a compreensão de tal tópico.

${ }^{50}$ Barzel (2004) estuda as características de mercados governados por um padrão. Porém, o autor não discute o processo de instituição desses arranjos, opção aqui seguida. Conforme já apontado anteriormente, há uma série de meios para o estudo de tal processo, entre os quais o recurso à teoria das convenções.

51 Exemplos de nichos com tais características são encontrados no próprio comércio justo, ou ainda no movimento de defesa pela compra de produtos alimentícios cultivados em áreas próximas ao local de residência. Para um estudo do mercado de "local food”, ver Hinrichs (2000, 2003).
} 
parte das transações realizadas segundo suas estipulações, cabendo às partes estabelecer arranjos alternativos para o restante desse intercâmbio. A reputação representa um importante fator na garantia de tais negócios, evidenciando a insuficiência dos padrões para a organização da vida econômica.

\subsection{O papel da qualidade no sistema Fairtrade}

Tendo em vista os aspectos discutidos nas seções anteriores, são diversos os fatores que denotam a relevância do problema da inserção para o segmento Fairtrade. Em primeiro lugar, foi mostrado que a mensuração dos atributos relevantes aproxima os mercados da concorrência perfeita (BARZEL, 2004), igualando os fornecedores. Dessa maneira, segmentos regulados por uma certificação, como é o caso de parte do comércio justo, deveriam possuir um padrão de inserção absolutamente aleatório, ou ainda, ligado a variáveis desvinculadas dos produtos oferecidos. Por exemplo, o contato prévio entre cafeicultores e importadores poderia figurar entre as possíveis explicações para o sucesso nesse segmento ${ }^{52}$.

Além disso, a fixação de um preço mínimo pela FLO torna a inserção mercadológica uma questão central no sistema Fairtrade. Afinal, com o abandono de tal política, a tendência seria a queda das cotações no mercado justo, dado o excesso de produção certificada. No entanto, a polêmica em torno dos efeitos derivados da existência desse preço não se limita ao papel da regulamentação para a garantia da remuneração dos cafeicultores. Entre os trabalhos dedicados ao tema, há uma preocupação crescente com o dimensionamento daquilo que o Fairtrade efetivamente oferece aos consumidores.

No caso do café, uma série de características físicas, tais como o tamanho do grão ou a qualidade da bebida, são utilizadas para sua diferenciação (SOUZA; SAES; OTANI, 2002). De fato, a exploração de aspectos relacionados a essas peculiaridades vem

\footnotetext{
52 De fato, a qualidade do café comercializado constitui apenas um requisito. Estudos dedicados ao tema (RAYNOLDS, 2002; TAYLOR, 2002; SAES; MIRANDA, 2007) apontam uma série de fatores que determinariam o sucesso das cooperativas ligadas ao Fairtrade, entre os quais a emergência de uma liderança nessas cooperativas e o apoio de organizações não governamentais (ONGs).
} 
motivando a adoção de estratégias específicas por parte de agentes envolvidos com a cafeicultura. Variáveis como a altitude, o tipo de solo e a variedade das plantas utilizadas tem papel fundamental no resultado final desse produto. Desse modo, é possível afirmar que há atributos vinculados à qualidade do café cuja existência resulta da combinação de características exclusivas de uma localidade.

Por outro lado, o selo Fairtrade se organiza em torno da mensuração de atributos sociais relacionados à produção agrícola. Ligadas à distribuição equitativa dos ganhos obtidos ao longo da cadeia, tais características estariam dissociadas do produto em si. Com isso, a cotação praticada nas transações realizadas segundo as regras do comércio justo deveria refletir, na teoria, a preocupação com a garantia de melhores condições de vida aos agricultores. Nesse sentido, Mann (2008) argumenta que o preço fixado pela FLO reflete a demanda por atributos simbólicos, como a garantia de respeito nas relações comerciais.

Devido a esse fato, a manutenção da política de preço mínimo constitui uma das pedras angulares do sistema administrado pela FLO. Entretanto, ações visando o controle das cotações podem gerar efeitos colaterais consideráveis, retirando incentivos para a adoção de determinadas estratégias. Por exemplo, a busca pela melhoria dos métodos produtivos pode ser desestimulada em um quadro de regulamentação do mercado (SAES, 1997). Baseado em tal histórico, Zehner (2002) afirma que o selo Fairtrade estimula a venda de café com baixa qualidade por parte dos produtores certificados.

Contrariando essa afirmação, o presidente da Transfair USA argumenta que as cooperativas fariam o oposto, vendendo os seus grãos de melhor qualidade aos importadores ligados ao sistema Fairtrade (RICE, 2002). Tal comportamento, segundo Paul Rice, se deve à necessidade de agradar os compradores, e assim garantir a venda de quantidades crescentes pelo preço estipulado pela FLO. Sob essa lógica, a fixação de um preço mínimo viabilizaria o investimento nos cafezais, estimulando os produtores a buscar uma inserção diferenciada no mercado.

Em meio a esse debate, chama a atenção a importância que a qualidade possui para um nicho de mercado que, supostamente, estaria organizado em torno de outros atributos. Ora, a superioridade do café está relacionada ao cuidado com os grãos no momento da colheita, ou ainda ao seu beneficiamento adequado. Da mesma maneira, as já citadas variáveis 
edafoclimáticas são fundamentais para garantir a qualidade da bebida. Tais fatores, porém, independem do tamanho das propriedades, sendo possível a produção de cafés especiais tanto por produtores familiares quanto em grandes propriedades.

Assim, o reconhecimento crescente da qualidade do café Fairtrade, enfatizado por Rice (2002), representa uma clara demonstração da insuficiência do sistema FLO para a organização do mercado justo. Em outras palavras, os fatores que explicariam o sucesso dos produtores ligados ao selo Fairtrade vão além do componente ético enfatizado por seus militantes. Afinal, quando o selo Max Havelaar, pioneiro no segmento, foi criado no final da década de 80 , foi a preocupação com as condições de vida dos cafeicultores familiares, e não a demanda por cafés especiais a principal motivação para tal iniciativa

No sistema Fairtrade, o que explica a oferta de cafés dotados de qualidade superior é a dificuldade de garantir a inserção nesse segmento. Ao contrário do diagnóstico de Zehner (2002), a fixação de um preço mínimo não impede que os beneficiários dessa política busquem formas de diferenciar sua produção. Na verdade, mais importante que a cotação são as alternativas dos agentes afetados por essa política. Caso tal mercado fosse caracterizado pela escassez de oferta de café certificado, as cooperativas detentoras do selo Fairtrade poderiam explorar tal quadro com o objetivo de capturar parte do valor relativo à espera dos compradores ${ }^{53}$.

Entretanto, o excesso de oferta no sistema Fairtrade torna tal estratégia inviável. Afinal, o pagamento referente à existência de atributos sociais depende da presença de outras características demandadas pelos fornecedores. No caso em tela, o valor inerente a tais atributos é dissipado quando o café certificado é vendido no mercado convencional. Dessa forma, a acirrada competição no comércio justo impõe a necessidade de uma diferenciação que vá além dos aspectos sociais atestados pela FLO. Não por acaso, características como a qualidade superior dos grãos produzidos, ou a conversão dos cafezais convencionais em orgânicos, são variáveis-chave para o entendimento da inserção das cooperativas no segmento Fairtrade.

\footnotetext{
${ }^{53}$ Por exemplo, essas iniciativas poderiam estimular o aumento da produção entre seus associados, ainda que tal medida acarretasse uma queda na qualidade média do produto. Afinal, o cuidado na seleção dos grãos constitui uma das ações mais importantes na garantia de um café com qualidade superior de bebida.
} 
Nesse sentido, a principal diferença entre o comércio justo e a regulamentação do mercado cafeeiro no Brasil, por exemplo, está na margem concedida aos agentes para sua atuação na esfera econômica. No caso brasileiro, o tabelamento de preços contribuiu decisivamente para a piora da qualidade média do café produzido no território nacional, em um processo que levou à queda acentuada no consumo do produto (SAES, 1997). Assim, a falta de opções para que os cafeicultores explorassem atributos pertencentes à suas lavouras fez com que mesmo aqueles indivíduos com um pendor para o empreendedorismo desistissem de colocar suas ideias em prática.

Já no segmento Fairtrade, a multiplicidade de alternativas faz com que os agentes possuam liberdade considerável para buscar um rearranjo das transações segundo seus interesses. Do lado dos importadores, a existência de um excesso de oferta abre a possibilidade de uma busca mais criteriosa do café adquirido, algo que vem contribuindo para que o padrão de inserção no comércio justo assuma as características aqui descritas. Por sua vez, as cooperativas tem buscado oferecer mais que atributos sociais aos interessados no café Fairtrade, como forma de garantir os benefícios derivados da participação nesse sistema, ou mesmo obter um preço maior que aquele estipulado pela FLO.

\subsection{O preço Fairtrade e o mercado internacional de café}

Transformado em argumento de defesa do sistema Fairtrade (RICE, 2002), o oferecimento de cafés com qualidade superior pelos cafeicultores certificados demonstra as limitações inerentes à busca pela regulamentação de um segmento de mercado. Afinal, sob o ponto de vista da FLO, o preço mínimo refletiria a demanda dos consumidores por atributos sociais vinculados aos bens agrícolas. Porém, o selo Fairtrade é apenas um dos muitos elementos a partir dos quais o mercado internacional de café se organiza. Consequentemente, a dinâmica observada no comércio justo deve levar em conta tendências mais amplas, como a busca por coordenação crescente entre os participantes dos sistemas agroindustriais (ZYLBERSZTAJN, 2005). 
No caso do Fairtrade, a inclusão das multinacionais no sistema solidário é a principal evidência da ligação entre esse segmento e o mercado internacional de café. Devido à dificuldade de garantir a inserção dos produtores certificados, a FLO passou a buscar parcerias com empresas anteriormente criticadas por sua militância. Como resultado de tal movimento, as taxas de crescimento das vendas de café Fairtrade tem sido consideráveis desde o final da década de 90, superando os dois dígitos na maioria dos países pesquisados (GIOVANNUCCI; KOEKOEK, 2003; FLO, 2007).

Por outro lado, a adesão das multinacionais ao comércio justo se resume ao pagamento dos preços estabelecidos pela FLO em parte das compras efetuadas. Mais especificamente, a entrada das multinacionais no sistema Fairtrade não acarretou a adoção do preço mínimo como única referência para suas compras. Pelo contrário, grande parte do café comercializado mundialmente por essas empresas se baseia em outros parâmetros, como a cotação divulgada pela bolsa de Nova Iorque, ou ainda os preços praticados nos mercados locais. Além disso, o compromisso com a transparência na divulgação das margens de lucro, uma das bandeiras históricas do movimento Fairtrade, não foi assumido por nenhum desses grupos.

Assim, a expansão do segmento Fairtrade não pode ser analisada de forma isolada em relação a outras tendências observadas no comércio internacional do café. $O$ próprio excesso de oferta aliado à adesão parcial das multinacionais aos princípios do comércio justo faz com que o oferecimento de atributos sociais seja insuficiente para explicar o acesso dos produtores aos benefícios estipulados pela FLO. Inclusive, a existência de cafés com qualidade superior no sistema Fairtrade vem permitindo às multinacionais a promoção de suas marcas sem que, para isso, sejam necessárias mudanças em suas estratégias.

De fato, o estabelecimento de relações de longo prazo com iniciativas detentoras do selo Fairtrade não difere de outras ações empreendidas pelas multinacionais na busca por um maior controle de qualidade da matéria-prima adquirida. Com isso, a participação dessas empresas no comércio justo está relacionada a um processo mais amplo, de aprofundamento da coordenação nas cadeias de suprimento. Ou seja, a fixação de um preço mínimo possui um papel menor do que o imaginado no comércio solidário. 
Exemplo disso é a utilização do índice NYBOT como um parâmetro para as oscilações na cotação Fairtrade. Tal medida demonstra a importância da qualidade no sistema administrado pela FLO, dados os requisitos para a participação na bolsa de Nova Iorque. Igualmente, o próprio acesso a tal informação não é instantâneo, sendo notável o fato de que milhões de produtores rurais desconhecem essa referência. Em outras palavras, a comparação entre o preço Fairtrade e aquela praticado no pregão novaiorquino demonstra a relação entre o comércio justo e os segmentos mais dinâmicos do comércio internacional de café.

A principal diferença entre ambos os sistemas, conforme mostra o gráfico 1 , reside na estabilidade do preço estabelecido pela FLO nos momentos de baixa no mercado internacional. Já nos períodos de alta, a cotação Fairtrade acompanha os ganhos observados na bolsa de Nova Iorque. Consequentemente, cooperativas ligadas ao comércio justo que sejam capazes de garantir sua inserção nesse segmento tem a garantia de maior previsibilidade em seus ingressos ${ }^{54}$.

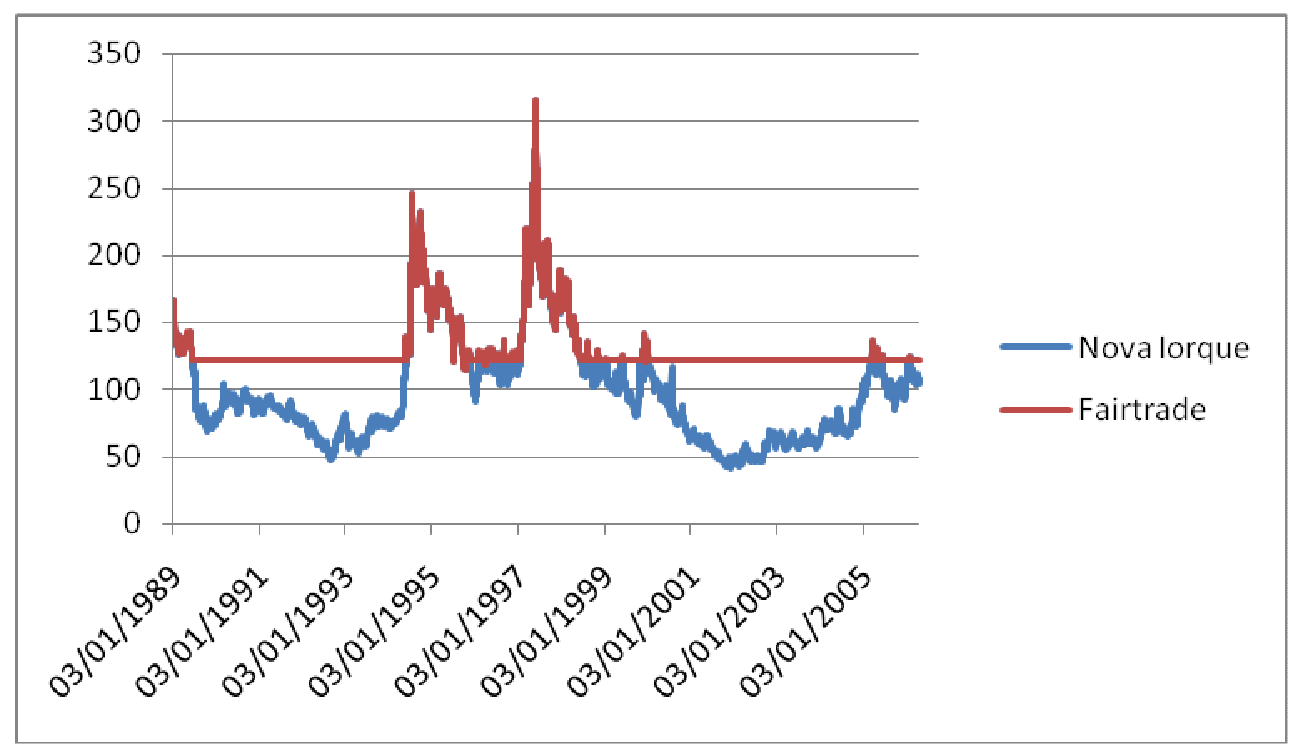

Gráfico 1: Cotações em Nova Iorque e o preço Fairtrade (centavos de US\$ por libra) FONTE: Elaborado pelo autor com dados de CIC (2008) e FLO (2009).

$\mathrm{Na}$ prática, porém, tais incentivos são semelhantes àqueles oferecidos por diversas multinacionais vinculadas ao segmento de cafés especiais. Embora não se caracterize pela garantia de estabilidade oferecida pela FLO, a política de preços de muitas dessas

\footnotetext{
${ }^{54}$ Ademais, a certificação Fairtrade determina o pagamento de um prêmio social, cuja utilização se restringe a projetos sociais. Tal benefício, de US\$ 0,10 por libra de café comercializado, nem sempre se traduz em mudanças nas comunidades, principalmente naqueles casos de inserção limitada no comércio justo.
} 
empresas se baseia na fixação de patamares superiores àquele prevalecente no mercado internacional. Nesse sentido, a estruturação de relações de longo prazo entre produtores certificados e os importadores se explica pela importância da reputação para o fornecimento de atributos não mensurados pela certificação solidária.

Os dados apresentados pelo gráfico 2 ajudam a demonstrar os efeitos práticos da existência do selo Fairtade. Historicamente, a cotação mínima estabelecida pela FLO é superior àquela praticada nos mercados de diversos países produtores ${ }^{55}$. Dessa maneira, caso a demanda por atributos sociais fosse o único motivo para a existência do mercado solidário, esse parâmetro nem precisaria acompanhar as oscilações do índice NYBOT para garantir uma remuneração superior aos cafeicultores. O acoplamento entre o preço Fairtrade e a bolsa de Nova Iorque, porém, implica a exigência de mais requisitos, o que acarreta o aumento dos custos de produção para os produtores inseridos nesse segmento.

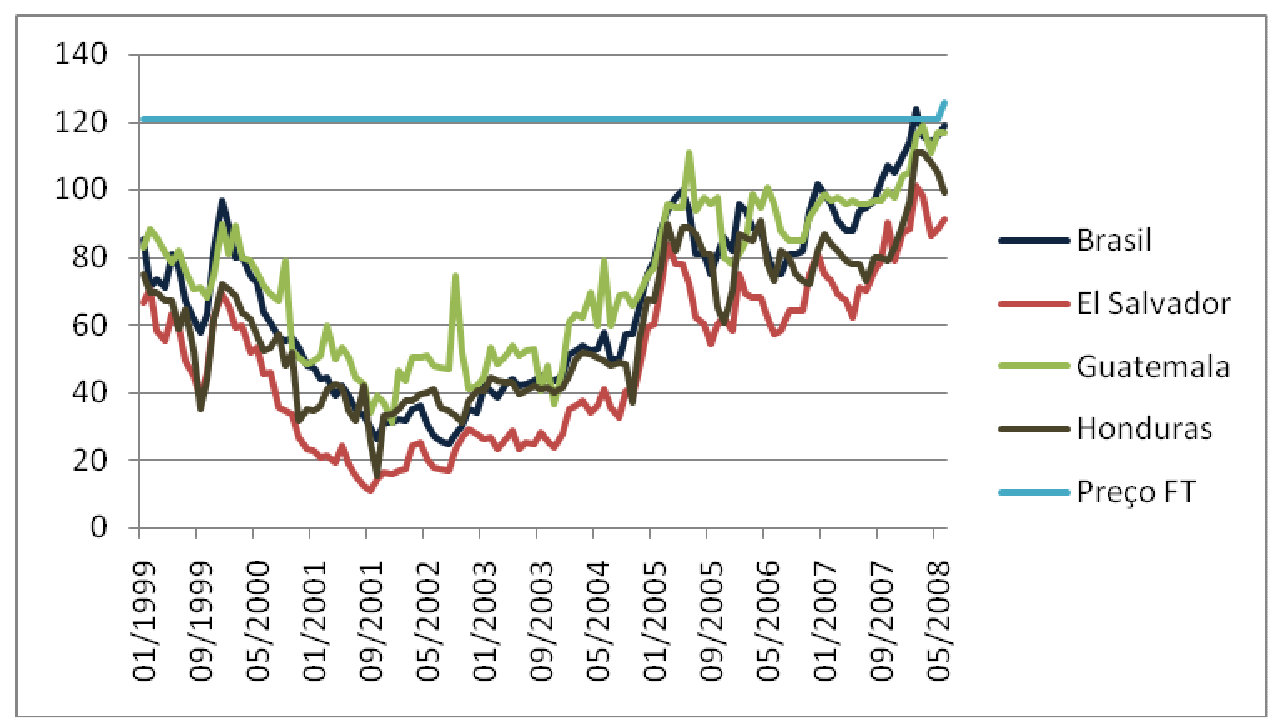

Gráfico 2: Preços pagos ao produtor e o preço mínimo FLO (centavos de US\$ por libra) FONTE: OIC (2009).

Não por acaso, a percepção dos cafeicultores certificados acerca do sistema administrado pela FLO varia de acordo com seu nível de inserção nesse segmento. Devido ao aumento nos gastos decorrentes da participação no mercado solidário, produtores filiados a cooperativas com dificuldades de comercializar o café produzido tem dificuldade para identificar os benefícios associados ao selo Fairtrade (FORT; RUBEN, 2008). Inclusive, é

\footnotetext{
55 Com a exceção da metade da década de 90, quando intempéries climáticas no Brasil contribuiram para a alta nas cotações nos principais mercados locais de café arábica.
} 
notável a tendência à comparação seus resultados com os de vizinhos inseridos nos mercados locais, cujos custos de produção são inferiores.

Por isso, o principal mérito do selo Fairtrade tem sido o de viabilizar a inclusão de milhares de produtores nos mercados de cafés especiais de países com alta renda per capta. Ao identificar grupos de cafeicultores baseados em regiões com condições edafoclimáticas favoráveis ao oferecimento de qualidade, a FLO contribui para sua integração aos segmentos mais dinâmicos desse setor. Entretanto, tal movimento não implica qualquer transformação no mercado internacional de café. Na verdade, a certificação solidária insere parte de seus integrantes em determinados filões dessa estrutura.

\subsection{A insuficiência das certificações}

São inúmeros os exemplos de sucesso entre as iniciativas detentoras do Fairtrade, o que demonstra a viabilidade da integração dos produtores familiares aos segmentos mais dinâmicos do mercado internacional de café. Afinal, conforme argumentam Litrell e Dickson (1997), ajudar os integrantes do comércio justo implica assegurar que estes sejam capazes de produzir artigos demandados pelas pessoas. Em meio a essa realidade, porém, é notável a recorrência à tese de que o sistema administrado pela FLO manifestaria a busca por mudanças profundas no sistema econômico internacional.

$\mathrm{Na}$ verdade, o debate acerca das reais intenções do sistema Fairtrade perde muito de sua força uma vez que a análise do discurso de seus militantes não vem sendo integrada à rotina dos agentes detentores da certificação. Independente das intenções da FLO, há determinadas características que são inerentes a qualquer padrão, como os claros limites para a organização dos mercados. Embora estabeleçam regras específicas para o funcionamento do comércio justo, seus administradores não tem qualquer garantia de que tais parâmetros serão aqueles adotados pelos indivíduos.

Nesse sentido, casos como o do acordo entre a UCIRI, cooperativa que motivou a instituição do selo Max Havelaar, e o Carrefour exemplificam a busca pela maximização do valor transacionado. Para analistas ligados à visão ambiciosa do sistema Fairtrade 
(RENARD, 2005), a decisão dessas organizações de comercializar café orgânico segundo regras decididas bilateralmente poderia significar o enfraquecimento dos princípios do comércio justo. No entanto, a própria heterogeneidade dos grupos ligados a esse movimento enfraquece qualquer julgamento acerca de um evento como o supracitado. Inclusive, os interesses dos produtores ligados ao selo Fairtrade muitas vezes se resumem à garantia de acesso aos mercados (JAFFEE, 2007).

Responsáveis pelo fornecimento de parte do produto comercializado no segmento dos cafés especiais, as cooperativas detentoras do selo Fairtrade tem recebido, em muitos casos, cotações superiores àquela estabelecida pela FLO. A própria recorrência a relacionamentos de longo prazo entre essas iniciativas e os importadores faz com que o preço mínimo constitua um mero parâmetro para as negociações posteriores. Fatores como a dificuldade de mensuração dos atributos demandados pelo comprador, ou seu nível de comprometimento com o comércio justo, contribuem para as diferenças nos preços observados.

No caso da agricultura orgânica, a existência de outros selos faz com que o estabelecimento de uma cotação seja facilitado. De fato, a FLO recomenda o pagamento de um prêmio de US\$ 0,20/libra para o café com dupla certificação. A tabela 1 apresenta dados de algumas cooperativas brasileiras vinculadas ao comércio justo ${ }^{56}$, demonstrando a importância da posse de mais de um selo para o êxito nesse segmento. Em outros países, tal quadro é semelhante, sendo notável o fato de que os produtores tendem a identificar com mais facilidade os benefícios derivados da adesão à agricultura orgânica do que ao sistema solidário (RAYNOLDS, 2002)

\footnotetext{
${ }^{56}$ No Brasil, o número de cooperativas de café vinculadas ao selo Fairtrade ultrapassa uma dezena.
} 
Tabela 1: Cooperativas brasileiras detentoras do selo Fairtrade

\begin{tabular}{|c|c|c|c|c|}
\cline { 2 - 5 } \multicolumn{1}{c|}{} & $\begin{array}{c}\text { Número de } \\
\text { cooperados }\end{array}$ & Produção total & $\begin{array}{c}\text { Porcentagem } \\
\text { de produção } \\
\text { orgânica }\end{array}$ & $\begin{array}{c}\text { Vendas } \\
\text { segundo as } \\
\text { regras da } \\
\text { FLO }\end{array}$ \\
\hline Cooperativa 1 & 3500 & 500.000 & $0,01 \%$ & $14 \%$ \\
\hline Cooperativa 2 & 260 & 40.000 & $0 \%$ & $10 \%$ \\
\hline Cooperativa 3 & 250 & 6.000 & $30 \%$ & $100 \%$ \\
\hline Cooperativa 4 & 250 & 14.000 & $35 \%$ & $85 \%$ \\
\hline
\end{tabular}

FONTE: Pesquisa de campo, 2009.

Já para a qualidade, a dificuldade de mensuração desse atributo torna improvável a existência de um preço único. Por isso, aqueles cafeicultores capazes de comprovar a superioridade de sua produção tem obtido cotações bastante superiores àquelas prevalecentes no sistema Fairtrade. Os resultados do I Concurso Internacional de Cafés do Comércio Justo, realizado no final de 2008, constituem uma importante evidência desse quadro. Entre outros fatores, o nível de conhecimento das iniciativas acerca das tendências no mercado internacional constitui um importante requisito para o aproveitamento dessas oportunidades.

Ademais, evidências mostram que as cotações pagas por importadores dedicados exclusivamente ao comércio justo são superiores à cotação oferecida por empresas vinculadas ao mercado convencional. Outro fator que influenciaria a distribuição dos ganhos na cadeia do Fairtrade seria o nível de conhecimento das cooperativas acerca das características necessárias à inserção no sistema solidário. Entretanto, a dificuldade de obtenção de dados amplos acerca do segmento, algo já enfatizado por outros autores (MOORE, 2004; RUBEN, 2008) tem impedido o teste de hipóteses relativas a aspectos globais comércio justo 57 .

Por outro lado, a concentração dos ganhos nos elos mais próximos dos consumidores se mantém semelhante no sistema Fairtrade. Dados colhidos na França demonstram que, na média, o preço médio desses produtos é superior aos artigos convencionais (Gráfico 3). O

\footnotetext{
${ }^{57}$ A considerável quantidade de estudos de caso dedicados ao sistema Fairtrade (TAYLOR, 2002; SAES; MIRANDA, 2007; JAFFEE, 2007; FORT; RUBEN, 2008; LUETCHFORD, 2008) demonstra tal realidade.
} 
fato de serem mais caros junto ao consumidor final não acarreta, porém, a transferência desse diferencial às cooperativas certificadas. Por estar inserida no segmento dos cafés especiais, a remuneração no comércio justo está parcialmente descolada daquela estabelecida pelos índices mais utilizados. Consequentemente, nada garante que a distribuição dos ganhos derivados da cooperação seja inferior em uma transação organizada no mercado internacional.

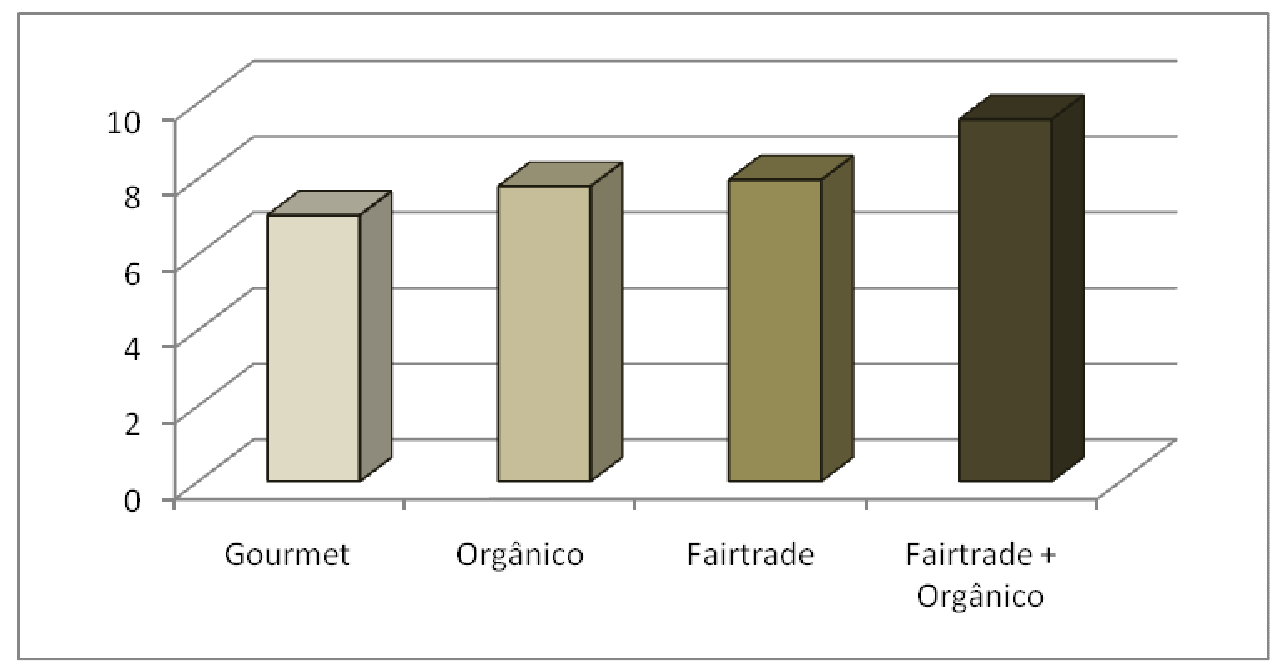

Gráfico 3: Médias de preços de cafés especiais em Montpellier (US\$ por libra)

FONTE: Pesquisa de campo, 2009.

$\mathrm{Na}$ verdade, mais importante que as regras estabelecidas pela FLO são as características dos agentes envolvidos nesse relacionamento. Nesse sentido, é possível apontar ao menos dois fatores que poderiam favorecer os cafeicultores vinculados ao selo Fairtrade em relação a seus concorrentes. Em primeiro lugar, a existência de agentes identificados com a causa do comércio justo pode levar a negociações em que a adoção de estratégias oportunistas seja improvável. Igualmente, o auxílio dado por diversas ONGs às cooperativas certificadas pela FLO viabiliza a chegada de informações fundamentais às regiões produtoras, de modo que as negociações realizadas pelas lideranças dessas iniciativas se beneficiariam desse fato. 
Resultado da mobilização de indivíduos com as mais variadas crenças políticas, o movimento comércio justo vem carregando, desde meados da década de 50, os anseios por melhores condições de vida a todos os humanos. Entre os variados projetos empreendidos por esses militantes, a certificação de produtos agrícolas é o que mais resultados econômicos vem rendendo. Nesse início de século XXI, é crescente o mercado dos produtos Fairtrade, assim como a sua reputação frente aos consumidores.

Todos os resultados colhidos pelo comércio solidário, porém, não podem obscurecer o fato de que o selo Fairtrade é uma certificação. Nesse sentido, deve ser analisado segundo as características assumidas por arranjos dessa natureza. Ao enfatizar o discurso de seus administradores, boa parte dos trabalhos dedicados ao sistema FLO limitam a integração entre aspectos empíricos e teóricos. Parte dessa dificuldade seria vencida a partir da realização de estudos com base em um ferramental que fosse capaz de apreender o cotidiano desse segmento.

Uma importante questão final diz respeito à identificação do padrão dos produtores beneficiados pelo comércio justo. Devido à tendência de introduzir esses indivíduos nos segmentos mais dinâmicos do mercado internacional do café, resta saber se o selo Fairtrade não estará auxiliando apenas os grupos em melhor situação entre os pequenos produtores. Em diversas regiões do mundo, a precariedade dos aparatos institucionais faz com que os sinais do mercado não cheguem, e a situação dos agricultores seja precária. Analisar até que ponto a certificação administrada pela FLO é capaz de garantir sua inserção efetiva no mercado solidário constitui um tema de pesquisa fundamental. 
Exemplos comuns na apresentação do modelo de concorrência perfeita, os mercados agrícolas estão assumindo um novo perfil. Desde o início da década de 80, a disseminação do uso de contratos na área vem exigindo esforços consideráveis por parte de seus pesquisadores. Como resultado, uma nova forma de enxergar a agricultura se originou, assegurando a análise de uma série de novos problemas. Em especial, a ascensão de abordagens inspiradas na Nova Economia Institucional a fim de interpretar tais transformações demonstra a importância da coordenação consciente da produção no setor.

Por outro lado, a aceitação do neoinstitucionalismo econômico somente veio após o reconhecimento de grande parte dos pilares sobre os quais a teoria neoclássica se assenta. Uma vez garantida a perenidade dessa vertente, porém, são necessários avanços que permitam o pleno aproveitamento de seu potencial. Afinal, se o cenário em que as análises econômicas se baseiam não é mais o mesmo após a conclusão de que as instituições importam, é evidente que muitos de seus resultados tampouco o serão.

Nesse sentido, o abandono da concepção abstrata dos mercados utilizada pelas ciências econômicas constitui uma prioridade. Indo além, tais estruturas devem passar a ser vistas não apenas de acordo com suas regras, como também a partir dos agentes que ali interagem. Embora seja capaz de promover o crescimento econômico, a garantia dos direitos de propriedade não basta. Principalmente nos países não desenvolvidos, as limitações relacionadas à atividade econômica podem originar quadros em que a geração de riqueza não resulte na recompensa adequada a todos os indivíduos.

Por isso, a avaliação dos resultados derivados de qualquer processo econômico deve levar em conta a possibilidade dos agentes assumirem as rédeas de seus destinos. No caso da agricultura, a diferenciação constitui um provável requisito para o aumento da renda no setor. Entretanto, tal processo não é suficiente. Garantir aos produtores rurais a capacidade de compreender a realidade econômica à sua volta, possibilitando que sua inserção nos segmentos mais dinâmicos do mercado reflita a iniciativa própria, é ainda mais importante. 


\section{REFERÊNCIAS}

ABRAMOVAY, Ricardo. Entre Deus e o diabo: mercados e interação humana nas ciências sociais. Tempo social, Vol. 16, No. 2, 2004.

AKERLOF, George A. The market for "lemons": quality uncertainty and the market mechanism. The Quarterly Journal of Economics, Vol. 84, No. 3, 1970.

ALCHIAN, Armen; DEMSETZ, Harold. Production, information costs, and economic organization. American Economic Review. Vol. 62, No. 5, 1972.

ARROW, Kenneth J. The organization of economic activity: issues pertinent to the choice of market versus nonmarket allocation. In: The analysis and evaluation of public expenditure: the PPT system. US Joint Economic Committee, 91 st Congress. 1st Session, US Government Printing Office, Vol. 1, 1969.

ARRUÑADA, Benito. The quasi-judicial role of large retailers: an efficiency hypothesis of their relation with suppliers. In: BROUSSEAU, Eric; GLACHANT, Jean-Michel. The economics of contracts: theories and applications. Cambridge: Cambridge University Press, 2002.

BARZEL, Yoram. The theory of rationing by waiting. Journal of Law and Economics, Vol. 17, No. 1, 1974.

Measurement cost and the organization of markets. Journal of Law and Economics, Vol. 25, No. 1, 1982.

The Capture of Wealth by Monopolists and the Protection of Property Rights. International Review of Law and Economics, Vol. 14, No. 4, 1994. 1997.

Economic analysis of property rights. New York: Cambridge University Press,

The role of contract in quality assurance. Current: Agriculture, Food \& Resource Issues, Vol. 1, No. 1, 2000.

A measurement cost based theory of the firm. Seattle, 2001. Disponível em: http://www.econ.washington.edu/user/yoramb. Acesso em 10/07/2006.

Standards and the form of agreement. Economic Inquiry, Vol. 42, No. 1, 2004.

Organizational forms and measurement costs. In: Conference of the International Society for the New Institutional Economics. Cambridge, Massachusetts, Proceedings, 2002.

BLOCK, Fred. Postindustrial possibilities: a critique of economic discourse. Berkeley: University of California Press, 1990. 
BOGETOFT, Peter; OLESEN, Henrik Ballebie. Design of production contracts: lessons from theory and agriculture. Copenhagen: Copenhagen Business School Press, 2004.

BROWN, Michael Barratt. Fair trade: reform and realities in the international trading system. London: Zed Books, 1993.

CALEMAN, Silvia Morales de Queiroz et al. Mecanismos de governança em sistemas agroalimentares - um enfoque nos custos de mensuração. Revista de Economia e Agronegócio, Vol. 4, No. 2, 2006.

CHEUNG, Steven N. S. A theory of price control. The Journal of Law and Economics. Vol. 17, No. 1, 1974.

The contractual nature of the firm. The Journal of Law and Economics, Vol. 26, No. 1, 1983.

COASE, Ronald H. The nature of the firm. Economica, Vol. 4, No. 16, 1937.

COASE, Ronald H. The problem of social cost. Journal of Law and Economics, Vol. 3, No. 1, 1960.

DAVIRON, Benoit; PONTE, Stefano. The coffee paradox: global markets, commodity trade and the elusive promise of development. London and New York: Zed Books in association with CTA, 2005.

DEMSETZ, Harold. Toward a theory of property rights. The American Economic Review, Vol. 52, No. 2, 1967.

. The theory of the firm revisited. In: WILLIAMSON, Oliver; WINTER, Sidney (Eds.). The nature of the firm: origin, evolution and development. Oxford: Oxford University Press, 1993.

EGGERTSSON, Thrainn. Economic behavior and institutions. Cambridge: Cambridge University Press, 1990.

ESPINO, José Ayala. Instituciones y economía: una introducción al neoinstitucionalismo económico. México, Distrito Federal: Fondo de Cultura Económica, 1999.

FAIRTRADE LABELLING ORGANIZATIONS INTERNATIONAL. Shaping global partnerships. Annual Report, 2006 / 2007. Bonn, 2007.

; OXFAM AUSTRALIA. Tackling poverty with trade: how Australians buying Fairtrade benefits producers in developing countries. Disponível em: http://www.oxfam.org.au. Acesso em 30/05/2009.

FLIGSTEIN, Neil. Market as politics: a political-cultural approach to market institutions. American Sociological Review, Vol. 61, No. 4, 1996. 
FORT, Ricardo; RUBEN, Ruerd. The impact of Fair Trade certification on coffee producers in Peru. In: RUBEN, Ruerd (Ed.). The impact of Fair Trade. Wageningen: Wageningen Academic Publishers.

FOSS, Kirsten; FOSS, Nicolai. A property rights perspective on competitive strategy. Copenhagen: Copenhagen Business Scholl. Working Paper, 2001.

The next step in the evolution of RBV: integration with transaction costs economics. Copenhagen: Copenhagen Business School. Working Paper, 2004.

FOSS, Nicolai. Strategy, economic, organization and the coordination of firms and resources. Oxford: Oxford University Press, 2005.

FRIDELL, Gavin. Fair trade coffee: the prospects and pitfall of market-driven social justice. Toronto: University if Toronto Press, 2007.

FURUBOTN, Eirik; RICHTER, Rudolf. Institutions and economic theory: the contribution of the New Institutional Economics. Ann Arbor: The University of Michigan Press, 2000.

GIOVANNUCCI, Daniele; KOEKOEK, Freek. The state of sustainable coffee: a study of twelve major markets. Cali: FERIVA S. A., 2003.

GIOVANNUCCI, Daniele; LIU, Pascal; BYERS, Alice. Adding value: certified coffee trade in North American. In: LIU, Pascal (Ed.). Value-adding standards in the North American Food Market: Trade opportunities in certified products for developing countries. Roma: FAO, 2008.

GRANOVETTER, Mark. The strength of weak ties. American Journal of Sociology, Vol. 78, No. 6, 1973.

Economic action and social structure: the problem of embeddedness. The American Journal of Sociology, Vol. 91, No. 3, 1985.

The impact of social structure on economic outcomes. Journal of Economic Perspectives, Vol. 19, No. 1, 2005.

HAYEK, Friedrich. The use of knowledge in society. American Economic Review, 34, 1945.

Economics and knowledge. In: Individualism and Economic Order. Chicago: University of Chicago Press, 1996 [c1948].

HENSON, Spencer; REARDON, Thomas. Private agri-food standards: implications for food policy and the agri-food system. Food Policy, 30, 2005.

HINRICHS, Clare C. Embeddedness and local food systems: notes on two types of direct agricultural markets. Journal of Rural Studies, 16, 2000. 

19, 2003.

The practice and politics of food system localization. Journal of Rural Studies,

JAFFEE, Daniel. Brewing justice: fair trade coffee, sustainability, and survival. Berkeley: University of California Press, 2007.

'Better but not great': the social and environmental benefits and limitations of Fair Trade for indigenous coffee producers in Oaxaca, Mexico. In: RUBEN, Ruerd (Ed.). The impact of Fair Trade. Wageningen: Wageningen Academic Publishers.

JOSKOW, P. L. The New Institutional Economics: Alternative Approaches. Journal of Institutional and Theoretic Economics, 151, 1995.

KALDOR, Nicholas. The equilibrium of the firm. The Economic Journal, 44, 1934.

KAPLINSKY, Raphael; FITTER, Robert. Technology and globalisation: who gains when commodities are de commodified? International Journal of Technology and Globalisation, Vol. 1, No. 1, 2004.

KNIGHT, Frank. Riesgo, incertidumbre y beneficio. Madrid: M. Aguilar, 1947.

KLEIN, Benjamin; CRAWFORD, Robert G; ALCHIAN, Armen. Vertical integration, appropriable rents, and the competitive contracting process. Journal of Law and Economics, Vol. 21, No. 2, 1978.

KLEIN, Benjamin. The role of incomplete contracts in self-enforcing relationships. In: BROUSSEAU, Eric; GLACHANT, Jean-Michel. The economics of contracts: theories and applications. Cambridge: Cambridge University Press, 2002.

KONING, Niek; CALO, Muriel; JONGENEEL, Roel. Fair trade in tropical crops is possible; international commodity agreements revisited. North-South Centre, Discussion paper No. 3 (Working Paper), Wageningen University, Holanda, 2004. Disponível em: http://ase.tufts.edu/gdae/Pubs/rp/KoningCaloFairtradeICAs2004.pdf, Acesso em: 10/12/2007.

KRASNER, Stephen. Business government relations: the case of the International Coffee Agreement. International Organization 27 (4), 1973.

LANGLOIS, Richard N. Transaction-cost economics in real time. Industrial and Corporate Change, Vol. 1, No. 1, 1992.

LITRELL, Mary; DICKSON, Marsha. Alternative trade organizations: shifting paradigm in a culture of social responsibility. Human Organization, Vol. 56, No. 3, 1997.

LOADER, Rupert. Transaction costs and relationship in agri-food systems. In: International Conference on Chain Management, Wageningen. Proceedings, 1995.

LUETCHFORD, Peter. Fair trade and a global commodity: coffee in Costa Rica. Ann Arbor: Pluto Press, 2008. 
MACHER, Jeffrey; RICHMAN, Barak. Transaction cost economics: an assessment of empirical research in the social sciences. Durham: Duke Law School. Legal Studies Research Paper Series, Research paper No. 115, 2006.

MACDONALD, James et al. Contracts, markets and prices: organizing the production and use of agricultural commodities. Washington DC: USDA Economic Research Center. Agricultural Economic Report \#837, 2004.

MACNEIL, Ian. Contracts: adjustment of long-term economic relations under classical, neoclassical and relational contract law. Northwestern University Law Review, 72, 1978.

MANN, Stefan. Analyzing fair trade in economic terms. The Journal of SocioEconomics, 37, 2008.

MASELAND, Robbert; DE VAAL, Albert. Fair trade and the income distribution. In: RUBEN, Ruerd (Ed.). The impact of Fair Trade. Wageningen: Wageningen Academic Publishers.

MASTEN, Scott E. Transaction-cost economics and the organization of agricultural transactions. In: BAYE, Michael (Ed.). Advances in applied microeconomics: industrial organization. New York: Elsevier, 2000

MENARD, Claude. On clusters, hybrids, and other strange forms: the case of the French poultry industry. Journal of Institutional and Theoretical Economics, Vol. 152, 1996.

MOORE, Geoff. The fair trade movement: Parameters, issues and future research. Journal of Business Ethics, 53, 2004.

MURRAY, Douglas; RAYNOLDS, Laura T. Globalization and its antinomies: negotiating a Fair Trade movement. In: RAYNOLDS, Laura T.; MURRAY, Douglas; WILKINSON, John. Fair Trade: the challenges of transforming globalization. London and New York: Routledge, 2007.

NICHOLLS, Alex; OPAL, Charlotte. Fair trade: market-driven ethical consumption. London: SAGE Publications, 2004.

NORTH, Douglass. Instituciones, cambio institucional y desempeño económico. México, Distrito Federal: Fondo de Cultura Económica, 1993.

PARETO, Vilfredo. Manual de economia política. São Paulo: Nova Cultural, 1987.

PIROTTE, Gautier; PLEYERS, Geoffrey; PONCELET, Marc. Fair Trade coffee in Nicaragua and Tanzania: a comparison. Development and practice, Vol. 16, No. 5, 2006.

PRADO, Eleutério F. S. Equilíbrio e entropia: crítica da teoria neoclássica. Econômica, Vol. 1, No. 2, 1999.

RAYNOLDS, Laura T. Re-embedding global agriculture: the international organic and fair trade movements. Agriculture and Human Values, 17, 2000. 
Consumer/Producer links in fair trade coffee networks. Sociologia ruralis, Vol. 42, No. 4, 2002a.

Poverty alleviation through participation in fair trade coffee networks: existing research and critical issues. Background paper prepared for project funded by the Community and Resource Development Program. New York: The Ford Foundation, 2002. Disponível em: http://www.colostate.edu/dept/Sociology, Acesso em: 10/02/2008/

; WILKINSON, John. Fair Trade in the agriculture and the food sector: analytical dimensions. In: RAYNOLDS, Laura T.; MURRAY, Douglas; WILKINSON, John. Fair Trade: the challenges of transforming globalization. London and New York: Routledge, 2007.

REARDON, Thomas; FARINA, Elizabeth. The rise of private food quality and safety standards: illustrations from Brazil. International Food and Agribusiness Management Review, Vol. 04, No. 04, 2001.

RENARD, Marie-Christine. Fair Trade: quality, market and conventions. Journal of Rural Studies, 19, 2003.

Quality certification, regulation and power in fair trade. Journal of Rural Studies, 21, 2005.

RICE, Paul. Fair Trade: a more accurate assessment. Rebuttal of ZEHNER, David C. An economic assessment of "Fair Trade" in coffee. Chazen Web Journal of International Business, 2002.

RICUPERO, Rubens. Uma crise de 99 anos. Folha de São Paulo, Opinião Econômica. São Paulo, 27/02/2005.

RIORDAN, Michael; WILLIAMSON, Oliver. Asset specificity and economic organization. International Journal of Industrial Organization, 3, 1985.

ROBINSON, Joan. The economics of imperfect competition. London: Macmillan, 1933.

RUBEN, Ruerd. The development impact of Fair Trade: from discourse to data. In: RUBEN, Ruerd (Ed.). The impact of Fair Trade. Wageningen: Wageningen Academic Publishers.

SAES, Maria Sylvia Macchione. A racionalidade econômica da regulamentação no mercado brasileiro de café. São Paulo: Annablume, Fundação de Amparo à Pesquisa do Estado de São Paulo (FAPESP), 1997.

; FARINA, Elizabeth Maria Mercier Querido. O agribusiness do café no Brasil. São Paulo: Editora Milkbizz, 1999.

; MIRANDA, Bruno Varella. La coordinación de acciones como alternativa para la obtención de la sustentabilidad económica y social en la producción de café en Brasil: la experiencia de Poço Fundo, en el estado de Minas Gerais. In: ORGANIZACIÓN DE LAS 
NACIONES UNIDAS PARA LA AGRICULTURA Y LA ALIMENTACIÓN (Org.) Entornos favorables para el desarrollo del sector agroindustrial. Santiago: FAO, 2007.

A distribuição de quase-renda e a estratégia de diferenciação no café. Revista de Administração Contemporânea, Vol. 11, No. 2, 1007.

Estratégias de diferenciação e apropriação da quase-renda na agricultura: a produção de pequena escala. São Paulo, 2008. Tese (Livre docência em Administração) Faculdade de Economia, Administração e Contabilidade da Universidade de São Paulo.

SELTEN, Reinhard. Bounded rationality. Journal of Institutional and Theoretical Economics, No. 146, 1990.

SHELANSKI, Howard; KLEIN, Peter. Empirical research in transaction costs economics: a review and assessment. Journal of Law, Economics and Organization, Individualism and Economic Order, Vol. 11, No. 2, 1995.

SIMON, Herbert. A behavioral model of rational choice. The Quarterly Journal of Economics, Vol. LXIX, 1955.

SMELSER, Neil; SWEDBERG, Richard. The handbook of economic sociology. New York: Russel Sage Foundation, 1994.

SMITH, Adam. An inquiry into the nature and causes of the wealth of nations. Indianapolis: Hacket Publishing Company, 1993.

SOUZA, Maria Célia; SAES, Maria Sylvia Macchione; OTANI, Malimiria Norico. Pequenos agricultores familiares e sua inserção no mercado de cafés especiais: uma abordagem preliminar. Informações econômicas, Vol. 32, No. 11, 2002.

STIGLER, George J. Imperfections in the capital market. Journal of Political Economy, $75,1967$.

TAYLOR, Peter Leigh. Poverty alleviation through participation in fair trade coffee networks: synthesis of case study research question findings. Background paper prepared for project funded by the Community and Resource Development Program. New York: The Ford Foundation, 2002. Disponível em: http://www.colostate.edu/dept/Sociology, Acesso em: 10/02/2008/

In the market but not of it: Fair Trade coffee and Forest Stewardship Council Certification as a market-based social change. World Development, 33, 2005.

; MURRAY, Douglas L; RAYNOLDS, Laura T. Keeping trade fair: governance challenges in the Fair Trade coffee initiative. Sustainable development, 13, 2005.

TRANSFAIR. Fair Trade almanac: 1998 - 2006. Disponível em: http://uhfairtrade.org/files/2006FairTradeAlmanac.pdf, Acesso em 10/01/2009. 
UZZI, Brian. The sources and consequences of embeddedness for the economic performance of organizations: the network effect. American Sociological Review, Vol. 61, No. 4, 1996.

WILKINSON, John. A new paradigm of economic analysis? Recent convergences in French social science and an exploration of the convention theory approach with a consideration of its application to the analysis of agrifood system. Economy and Society, Vol. 26, No. 3, 1997.

A contribuição da teoria francesa das convenções para os estudos agroalimentares: algumas considerações iniciais. Ensaios FEE, Vol. 20, No. 2, 1999.

WILLIAMSON, Oliver. Credible commitments: using hostages to support exchange. American Economic Review, Vol. 73, No. 4, 1983.

. The economic institutions of capitalism. New York: The Free Press, 1985.

Comparative economic organization: the analysis of discrete structural alternatives. Administrative Science Quaterly, Vol. 36, No. 2, 1991.

Calculativeness, trust and economic organization. Journal of Law and Economics, Vol. 36, No. 1, 1993a.

. Opportunism and its critics. Managerial and Decision Economics, Vol. 14, No. 2, Special Issue: Transaction costs economics, $1993 \mathrm{~b}$.

The mechanisms of governance. Oxford: Oxford University Press, 1996.

The New Institutional Economics: taking stock, looking ahead. Journal of Economic Literature, Vol. XXXVIII, 2000.

YANCHUS, Dennis; de VANSSAY, Xavier. The myth of fair prices: a graphical analysis. Journal of Economic Education, Vol., 34, No. 3, 2003.

ZEHNER, David C. An economic assessment of "Fair Trade" in coffee. Chazen Web Journal of International Business, 2002.

ZYLBERSZTAJN, Decio. Governance structures and agribusiness coordination: a transaction cost economics based approach. In: GOLDBERG, Ray (Ed.). Research in domestic and international agribusiness management, Vol. 12. London: Jai Press Inc, 1996.

Measurement cost and transaction cost perspectives of the firm: two views about the same subject. In: Conference of the International Society for the New Institutional Economics, Barcelona. Proceedings, 2005a.

Papel dos contratos na coordenação agro-industrial: um olhar além dos mercados.

Revista de Economia e Sociologia Rural, Vol. 43, No. 3, 2005b. 